Nevada

Environmental

Restoration

Project

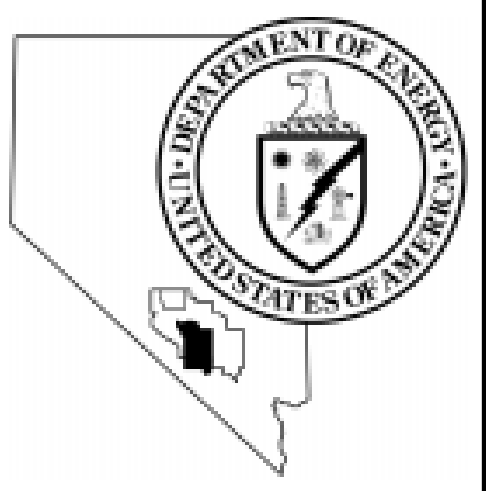

Corrective Action Investigation Plan

for Corrective Action Unit 335:

Area 6 Injection Well and Drain Pit

Nevada Test Site, Nevada

Controlled Copy No::

Revision No.: 0

December 2000

Approved for public release; further dissemination unlimited.

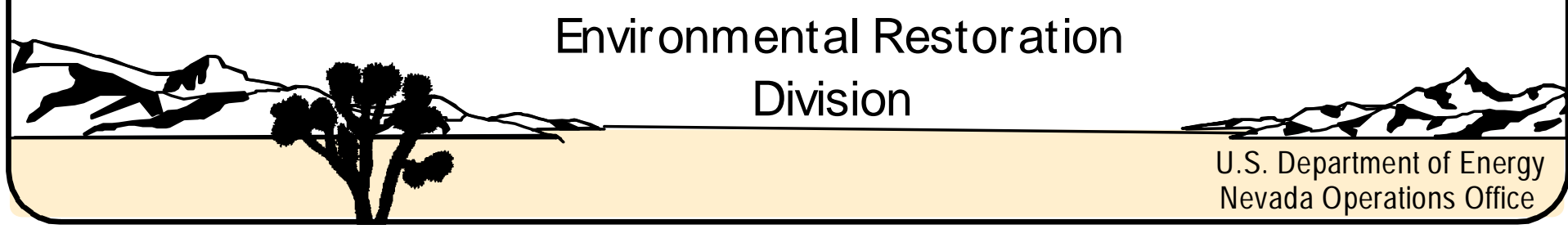


Available for public sale, in paper, from:

\author{
U.S. Department of Commerce \\ National Technology Information Service \\ 5285 Port Royal Road \\ Springfield, VA 22161 \\ Phone: 800.553 .6847 \\ Fax: 703.605.6900 \\ Email: orders@ntis.fedworld.gov \\ Online ordering: http//www.ntis.gov/ordering.htm
}

Available electronically at http://www.doe.gov/bridge.

Available for a processing fee to U.S. Department of Energy and its contractors, in paper, from:

U.S. Department of Energy

Office of Scientific and Technical Information

P.O. Box 62

Oak Ridge, TN 37831-0062

Phone: 865.576 .8401

Fax: 865.576.5728

Email: reports@adonis.osti.gov

Reference herein to any specific commercial product, process, or service by trade name, trademark, manufacturer, or otherwise, does not necessarily constitute or imply its endorsement, recommendation, or favoring by the United States Government or any agency thereof or its contractors or subcontractors. 


\title{
CORRECTIVE ACTION INVESTIGATION PLAN FOR CORRECTIVE ACTION UNIT 335: AREA 6 INJECTION WELL AND DRAIN PIT NEVADA TEST SITE, NEVADA
}

\author{
DOE Nevada Operations Office \\ Las Vegas, Nevada
}

Controlled Copy No.:

Revision No.: 0

December 2000

Approved for public release; further dissemination unlimited. 


\section{CORRECTIVE ACTION INVESTIGATION PLAN \\ FOR CORRECTIVE ACTION UNIT 335: \\ AREA 6 INJECTION WELL AND DRAIN PIT \\ NEVADA TEST SITE, NEVADA}

Approved by:

Signature Approved

Date: $\quad 12 / 1 / 00$

Janet Appenzeller-Wing, Project Manager

Industrial Sites Project

Approved by:

Signature Approved

Date: $\quad 12 / 1 / 00$

Runore C. Wycoff, Division Director

Environmental Restoration Division 


\section{Table of Contents}

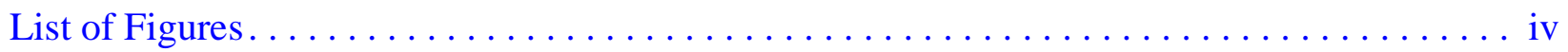

List of Tables $\ldots \ldots \ldots \ldots \ldots \ldots \ldots \ldots \ldots \ldots \ldots \ldots \ldots \ldots \ldots \ldots \ldots \ldots$

List of Acronyms and Abbreviations $\ldots \ldots \ldots \ldots \ldots \ldots \ldots \ldots \ldots \ldots \ldots \ldots \ldots \ldots \ldots \ldots$

Executive Summary . . . . . . . . . . . . . . . . . . . . . ES-1

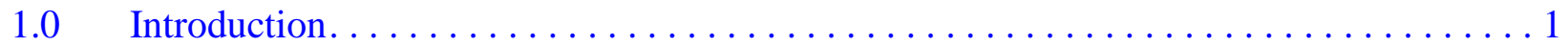

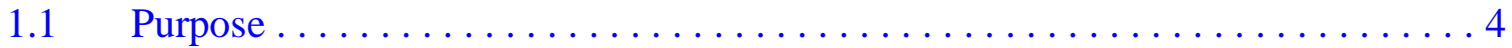

$1.2 \quad$ Scope. .................................. 4

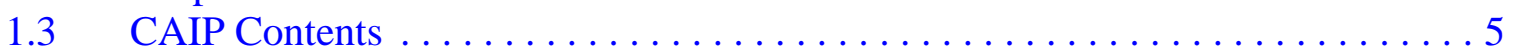

$2.0 \quad$ Facility Description. . . . . . . . . . . . . . . . 7

$2.1 \quad$ Physical Setting. . . . . . . . . . . . . . . . . . . 7

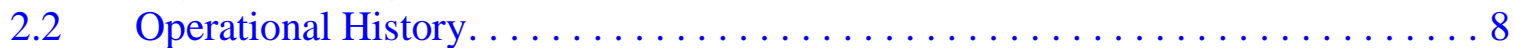

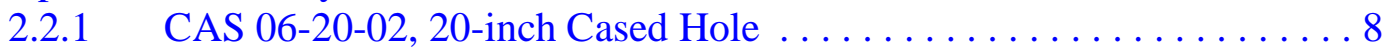

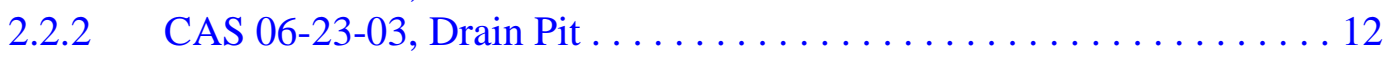

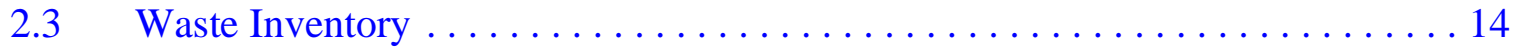

2.3.1 CAS 06-20-01, Drums; Oil Waste; Spills . . . . . . . . . . . . . . . 14

2.3.2 CAS 06-20-02, 20-inch Cased Hole .................. 16

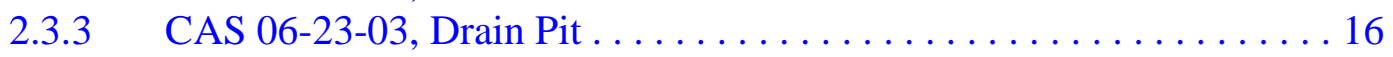

$2.4 \quad$ Release Information . . . . . . . . . . . . . . . . . . . . 16

2.4.1 CAS 06-20-01, Drums; Oil Waste; Spill . . . . . . . . . . . . . . . . 17

2.4.2 CAS 06-20-02, 20-inch Cased Hole . . . . . . . . . . . . . . . . . . 17

2.4.3 CAS 06-23-03, Drain Pit . . . . . . . . . . . . . . . . . 17

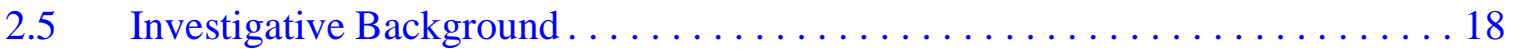

2.5.1 CAS 06-20-01, Drums; Oil Waste; Spill . . . . . . . . . . . . . . . 18

2.5.2 CAS 06-20-02, 20-inch Cased Hole . . . . . . . . . . . . . . . . 18

2.5.3 CAS 06-23-03, Drain Pit ...................... 20

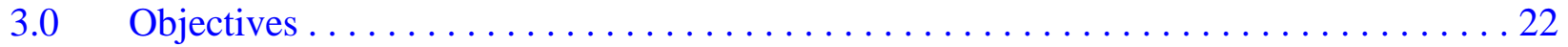

$3.1 \quad$ Conceptual Site Model . . . . . . . . . . . . . . . . . . . . . 22

3.2 Contaminants of Potential Concern . . . . . . . . . . . . . . . . . 23

3.3 Preliminary Action Levels . . . . . . . . . . . . . . . . . . . 23

3.3.1 Field-Screening Levels . . . . . . . . . . . . . . . . . . . 24

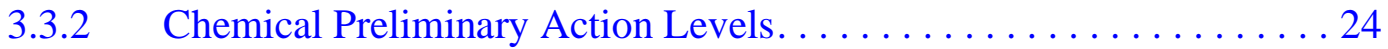

3.3.3 Radiological Preliminary Action Levels . . . . . . . . . . . . . . . . . . . . 24

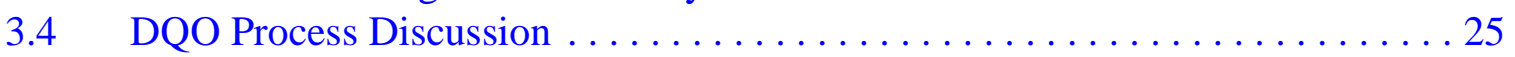

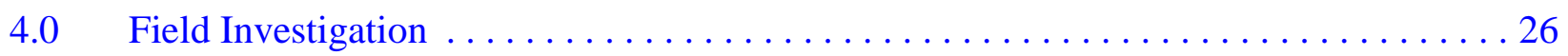

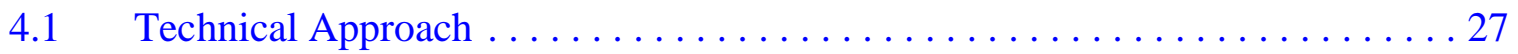




\section{Table of Contents (Continued)}

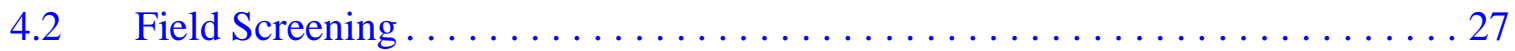

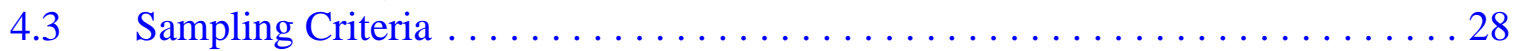

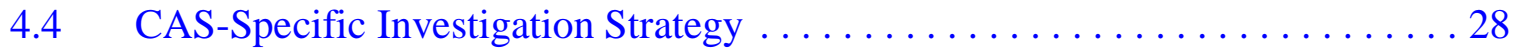

4.4.1 CAS 06-20-02, 20-inch Cased Hole . . . . . . . . . . . . . 28

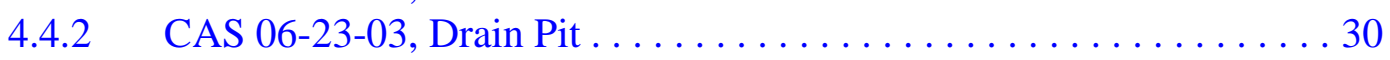

4.4.2.1 Drain Pipe Investigation $\ldots \ldots \ldots \ldots \ldots \ldots \ldots \ldots \ldots \ldots \ldots \ldots \ldots \ldots \ldots \ldots$

$5.0 \quad$ Waste Management. . . . . . . . . . . . . . . . . . . . . . . . . 34

$5.1 \quad$ Waste Minimization . . . . . . . . . . . . . . . . . . . . . . . . . 34

5.2 Potential Waste Streams . . . . . . . . . . . . . . . . . . . 35

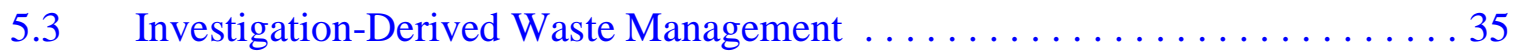

5.3.1 Nonhazardous Waste (Solid/Sanitary) . . . . . . . . . . . . . . . 35

5.3 .2 Hydrocarbon Waste . . . . . . . . . . . . . . . . . . 35

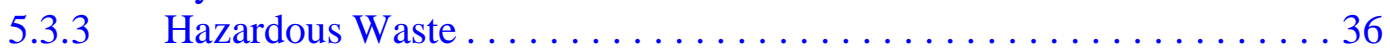

5.3.4 Low-Level Radioactive Waste. . . . . . . . . . . . . . . . 37

$5.3 .5 \quad$ Mixed Waste . . . . . . . . . . . . . . . . . . . . 38

5.4 Analysis Required for the Disposal of IDW . . . . . . . . . . . . . . 39

$6.0 \quad$ Duration and Records Availability . . . . . . . . . . . . . . . . 40

6.1 Duration ................................40

6.2 Records Availability ....................... 40

$7.0 \quad$ References.................................. 41

\section{Appendix A - Data Quality Objectives Worksheets}

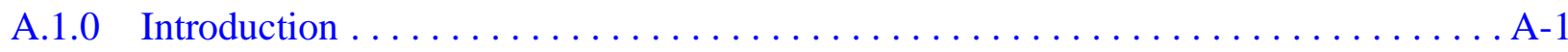

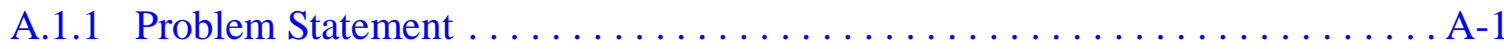

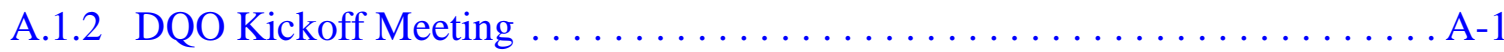

A.2.0 Conceptual Model. . . . . . . . . . . . . . . . . . . . . . . . . . A-3

A.3.0 Potential Contaminants . . . . . . . . . . . . . . . . . . . A-10

A.3.1 CAS 06-20-02, 20-inch Cased Hole . . . . . . . . . . . . . . . . . A-10

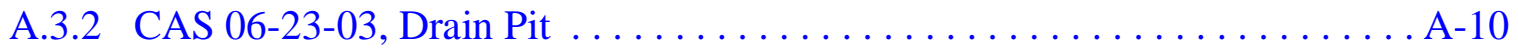

A.4.0 Decisions and Inputs $\ldots \ldots \ldots \ldots \ldots \ldots \ldots \ldots \ldots \ldots \ldots \ldots \ldots \ldots \ldots$

A.4.1 Decisions................................. A-14

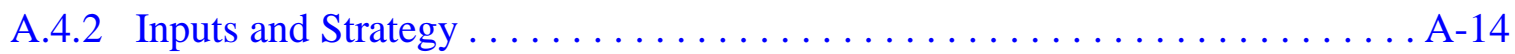

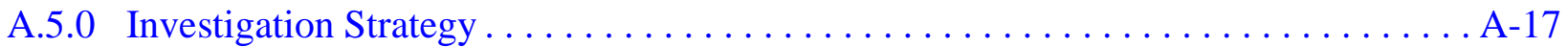

A.5.1 CAS 06-20-02, 20-inch Cased Hole . . . . . . . . . . . . . . . . . A-17 


\section{Table of Contents (Continued)}

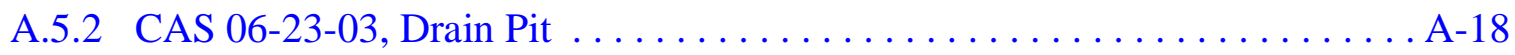

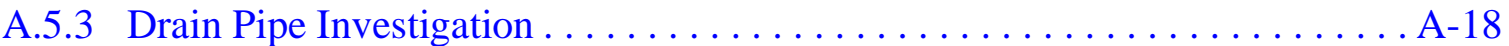

A.5.3.1 Plastic Pipe. ....................... A-18

A.5.3.2 Steel Drain Pipes ...................... A-19

A.6.0 Decision Rules . . . . . . . . . . . . . . . . . . . . . . . . A-20

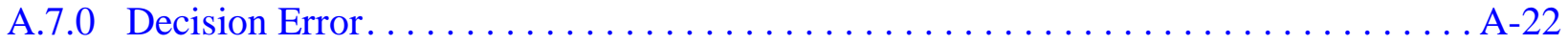

A.8.0 References................................... A-23

Appendix B - Project Organization

B.1.0 Project Organization . . . . . . . . . . . . . . . .

Appendix C - Laboratory Chemical, Toxicity Characteristic Leaching Procedure, and Radiochemistry Analytical Requirements for Industrial Sites

C.1.0 References..................................... C-7 


\section{List of Figures}

Number

Title

Page

1-1 Nevada Test Site and CAU 335, Nye County, Nevada. . . . . . . . . . . . . 2

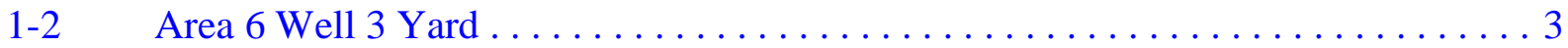

2-1 Site Location Map, CAS 06-20-02 and CAS 06-23-03. . . . . . . . . . 9

2-2 Photograph of Former Location of CAS 06-20-02, 20-inch Cased Hole,

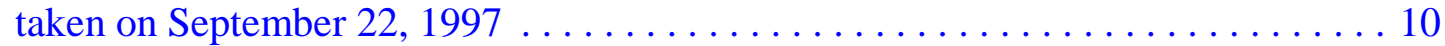

2-3 Photograph of CAS 06-23-03, Drain Pit, taken on July 21, $1998 \ldots \ldots \ldots \ldots \ldots 13$

2-4 Photograph of Drain Pipes in CAS 06-23-03, Drain Pit, taken on July 21,1998 and July $8,1999 \ldots \ldots \ldots \ldots$

4-1 Proposed Sample Location Map CAS 06-20-02 . . . . . . . . . . . . . . . . 29

4-2 Proposed Sample Location Map CAS 06-23-03 . . . . . . . . . . . . . . . . 31

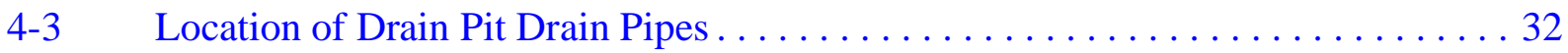

A.2-1 Diagrammatic Sketch of CAS 06-20-02, 20-inch Cased Hole . . . . . . . . . . . . A-4

A.2-2 Diagrammatic Sketch of CAS 06-23-03, Drain Pit............... A-5 


\section{List of Tables}

Number

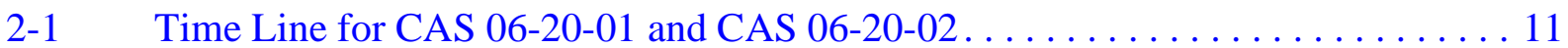

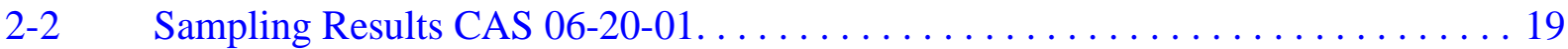

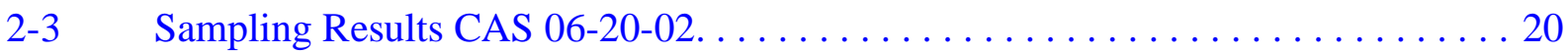

5-1 Waste Management Regulations and Requirements . . . . . . . . . . . 36

A.1-1 DQO Kickoff Meeting Participants. ....................... A-2

A.2-1 Conceptual Model for CAU 335, Area 6 Injection Well and Drain Pit ....... A-6

A.3-1 COPCs for CAS 06-20-02, 20-inch Cased Hole . . . . . . . . . . . . . . . . . . . . A-12

A.3-2 COPCs for CAS 06-23-03, Drain Pit $\ldots \ldots \ldots \ldots \ldots \ldots \ldots \ldots \ldots \ldots \ldots \ldots \ldots \ldots$

A.4-1 Decisions, Inputs, and General Strategies . . . . . . . . . . . . . . . . . . A A-15

C.1-1 Laboratory Chemical, Toxicity Characteristic Leaching Procedure, and Radiochemistry Analytical Requirements for Industrial Sites . . . . . . . . . C-1 


\section{List of Acronyms and Abbreviations}

bgs Below ground surface

CADD Corrective Action Decision Document

CAIP Corrective Action Investigation Plan

CAS Corrective Action Site

CAU Corrective Action Unit

CFR Code of Federal Regulations

Co Cobalt

COPC Contaminant(s) of potential concern

Cs Cesium

DOE U.S. Department of Energy

DOE/NV U.S. Department of Energy, Nevada Operations Office

DOT U.S. Department of Transportation

DQO Data Quality Objective

EPA U.S. Environmental Protection Agency

$\mathrm{Eu} \quad$ Europium

FFACO Federal Facility Agreement and Consent Order

FSL Field-screening level

FSR Field-screening reading

$\mathrm{ft} \quad$ Foot (feet)

gal Gallon(s)

HASP Health and Safety Plan

H\&N Holmes and Narver, Inc.

HWAA Hazardous waste accumulation area

HWAS Hazardous waste accumulation site

IDW Investigation-derived waste

in. Inch(es) 


\section{List of Acronyms and Abbreviations (Continued)}

\begin{tabular}{|c|c|}
\hline ISMS & Integrated Safety Management System \\
\hline ITLV & IT Corporation, Las Vegas \\
\hline LLW & Low-level radioactive waste \\
\hline $\mathrm{mg} / \mathrm{kg}$ & Milligram(s) per kilogram \\
\hline $\mathrm{mi}$ & Mile(s) \\
\hline NAC & Nevada Administrative Code \\
\hline NDEP & Nevada Division of Environmental Protection \\
\hline NTS & Nevada Test Site \\
\hline NTSWAC & Nevada Test Site Waste Acceptance Criteria \\
\hline PAL & Preliminary action level \\
\hline PCB & Polychlorinated biphenyl \\
\hline PPE & Personal protective equipment \\
\hline ppm & Part(s) per million \\
\hline PRG & Preliminary remediation goal \\
\hline $\mathrm{Pu}$ & Plutonium \\
\hline QA & Quality assurance \\
\hline QAPP & Quality Assurance Project Plan \\
\hline QC & Quality control \\
\hline $\mathrm{RCA}$ & Radioactive Controlled Area \\
\hline RCRA & Resource Conservation and Recovery Act \\
\hline REECo & Reynolds Electrical \& Engineering Co., Inc. \\
\hline RMA & Radioactive Materials Area \\
\hline SAA & Satellite Accumulation Area \\
\hline $\mathrm{Sr}$ & Strontium \\
\hline SSHASP & Site-Specific Health and Safety Plan \\
\hline SVOC & Semivolatile organic compound(s) \\
\hline
\end{tabular}




\section{List of Acronyms and Abbreviations (Continued)}

TPH Total petroleum hydrocarbon(s)

U Uranium

UVF Ultraviolet fluorescence

VOC Volatile organic compound 


\section{Executive Summary}

The Corrective Action Investigation Plan for Corrective Action Unit 335, Area 6 Injection Well and Drain Pit, has been developed in accordance with the Federal Facility Agreement and Consent Order that was agreed to by the U.S. Department of Energy, Nevada Operations Office; the State of Nevada Division of Environmental Protection; and the U.S. Department of Defense. Corrective Action Unit 335 consists of the following Corrective Action Sites:

- Corrective Action Site 06-20-01, Drums; Oil Waste; Spill

- Corrective Action Site 06-20-02, 20-inch Cased Hole

- Corrective Action Site 06-23-03, Drain Pit

Unknown concentrations and volumes of hydrocarbons, chemical constituents, and radionuclides may have been released in surface and subsurface soils at two of the three Corrective Action Sites within this Corrective Action Unit. These releases were a result of disposal of used motor oil, potentially contaminated wastewater, and solid debris in a vertically emplaced well casing, Corrective Action Site 06-20-02, 20-inch Cased Hole. In addition, effluent from truck washing operations was discharged into an unpermitted and unlined drain pit, Corrective Action Site 06-23-03. Piping associated with this Corrective Action Site may also be contaminated.

Corrective Action Site 06-20-01, Drums; Oil Waste; Spill consisted of four 55-gallon drums containing material pumped from Corrective Action Site 06-20-02, 20-inch Cased Hole. The drums were transported to the Area 5 Hazardous Waste Accumulation Site in July 1991. Since the drums are no longer on site, this Corrective Action Site will be closed with no further action required as described in the forthcoming Closure Report for Corrective Action Unit 335. Any spills that may have been associated with this Corrective Action Site will be investigated under Corrective Action Site 06-20-02, 20-inch Cased Hole.

Based on the site history collected to support the Data Quality Objectives process, contaminants of potential concern include volatile organic compounds, semivolatile organic compounds, Resource Conservation and Recovery Act metals, petroleum hydrocarbons, polychlorinated biphenyls, gammaemitting radionuclides, isotopic plutonium, isotopic uranium, and strontium-90. A conceptual site model for the Corrective Action Unit was developed and is summarized as follows: 
- Since Corrective Action Site 06-20-01, Drums; Oil Waste; Spill no longer exists, it will be closed with no further action as described in the forthcoming Closure Report.

- The contaminants of potential concern, if present, are associated with disposal of used motor oil and wastewater (Corrective Action Site 06-20-02) and effluent discharge from truck washing activities (Corrective Action Site 06-23-03).

- Lateral contamination is not expected to exceed the defined historical boundaries of each Corrective Action Site.

- Vertical contamination is not expected to exceed 15 feet below ground surface at each Corrective Action Site.

- The construction, geometry, and source(s) of the drain pipes associated with Corrective Action Site 06-23-03, Drain Pit are not fully known.

- Exposure pathways are ingestion, inhalation, and dermal contact.

- Groundwater impact is unlikely because the depth to groundwater is extensive (approximately 1,500 feet below ground surface at Water Well 3, located about 1,250 feet northwest of the site) and the environmental conditions at the site (i.e., arid climate, high evaporation) are not conducive to downward migration of contaminants of potential concern.

A more detailed conceptual site model is presented in Section 3.0 and Section A.2.0 of this Corrective Action Investigation Plan. The conceptual model serves as the basis for the sampling strategy.

The technical approach for investigating this Corrective Action Unit consists of the following activities:

- Select sample locations in likely worst-case areas to increase the level of certainty of finding contaminants of potential concern, if any.

- Collect surface and subsurface environmental soil samples using drilling methods such as hollow-stem auger or direct-push techniques.

- Collect quality control samples.

- Field-screen soil samples for volatile organic compounds, total petroleum hydrocarbons, and alpha/beta-emitting radionuclides.

- Conduct laboratory analyses of selected environmental soil samples and quality control samples for contaminants of potential concern identified in Section A.3.0, using laboratory methods identified in Appendix C. 
- Investigate piping associated with CAS 06-23-03, Drain Pit, using a combination of visual, video, and electromagnetic surveys. Collect sediment samples in the piping (if possible) and submit for laboratory analysis.

Additional sampling and analytical details are presented in Section 4.0, and details of the waste management strategy are included in Section 5.0 of this Corrective Action Investigation Plan.

Under the Federal Facility Agreement and Consent Order, the Corrective Action Investigation Plan will be submitted to the Nevada Division of Environmental Protection for approval. Field work will be conducted following approval of the plan. The results of the field investigation will support a defensible evaluation of corrective action alternatives in the Corrective Action Decision Document. 


\subsection{Introduction}

This Corrective Action Investigation Plan (CAIP) has been developed in accordance with the Federal Facility Agreement and Consent Order (FFACO) that was agreed to by the U.S. Department of Energy, Nevada Operations Office (DOE/NV); the State of Nevada Division of Environmental Protection (NDEP); and the U.S. Department of Defense (FFACO, 1996). The CAIP is a document that provides or references all of the specific information for investigation activities associated with Corrective Action Units (CAUs) or Corrective Action Sites (CASs). According to the FFACO, CASs are sites potentially requiring corrective action(s) and may include solid waste management units or individual disposal or release sites. A CAU consists of one or more CASs grouped together based on geography, technical similarity, or agency responsibility for the purpose of determining corrective actions.

This CAIP contains the environmental sample collection objectives and criteria for conducting site investigation activities at CAU 335, Area 6 Injection Well and Drain Pit. This CAU is located in the Well 3 Yard in Area 6 of the Nevada Test Site (NTS). The NTS is approximately 65 miles (mi) northwest of Las Vegas, Nevada (Figure 1-1). The Well 3 Yard is located 24 mi north of Mercury, Nevada, on the Mercury Highway and several hundred feet west along Road 6-06 which bisects the yard (Figure 1-2).

CAU 335 is comprised of the following CASs:

- CAS 06-20-01, Drums; Oil Waste; Spill

- CAS 06-20-02, 20-inch Cased Hole (Cased Hole)

- CAS 06-23-03, Drain Pit (Drain Pit)

The Cased Hole was used for disposal of used motor oil, wastewater, and debris, and the Drain Pit received effluent from truck washing activities. CAS 06-20-01, Drums; Oil Waste; Spill consisted of four 55-gallon drums containing material removed from the Cased Hole. Historical documents show that the drums were transported to the Area 5 Hazardous Waste Accumulation Site (HWAS) in July 1991 (REECo, 1992). The drums are no longer on site which precludes any further investigation or remediation; therefore, the CAS will be closed with no further action as described in the forthcoming Closure Report for this CAU. Any spills that may have been associated with this CAS will be investigated and addressed under CAS 06-20-02. 


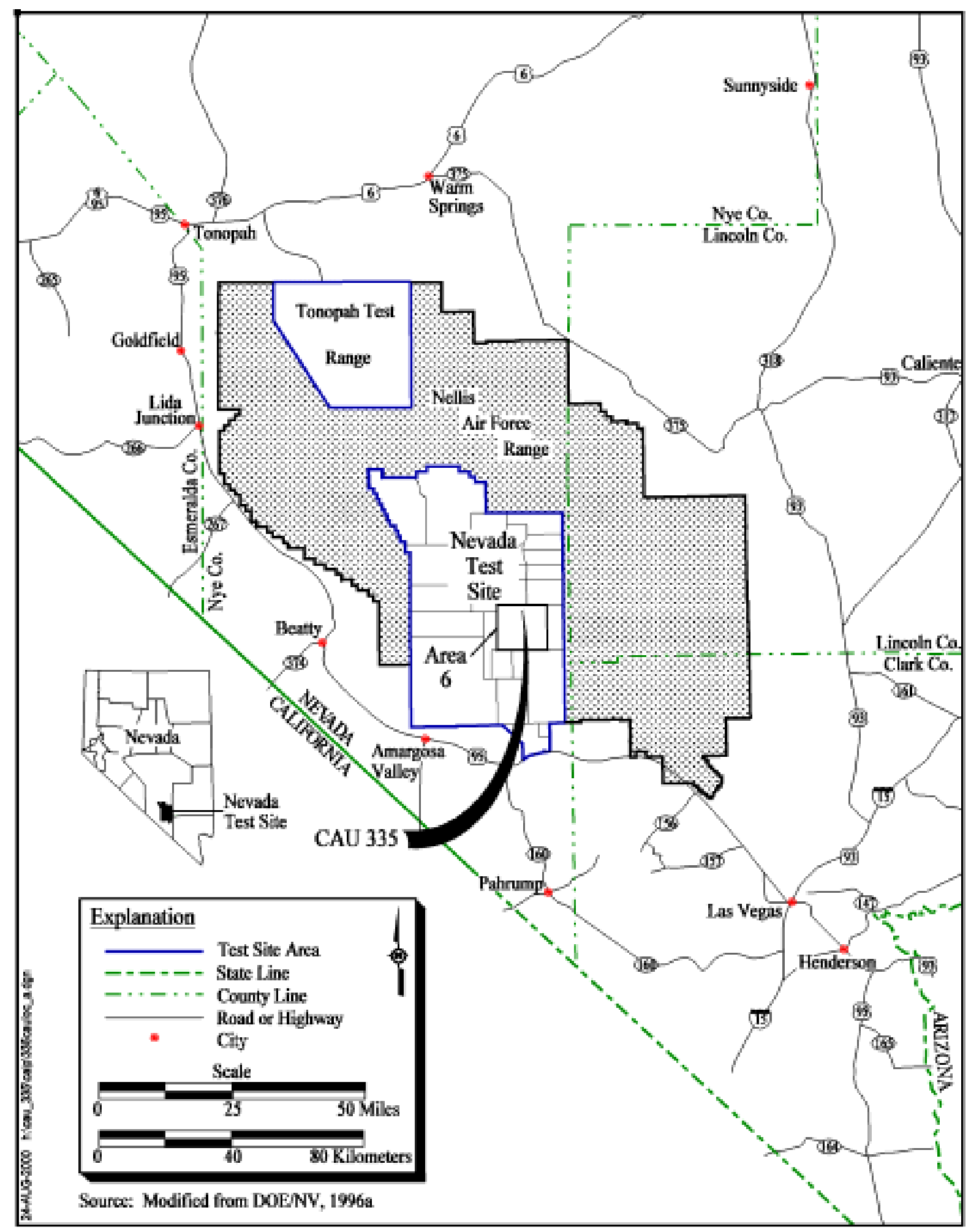

Figure 1-1

Nevada Test Site and CAU 335, Nye County, Nevada 


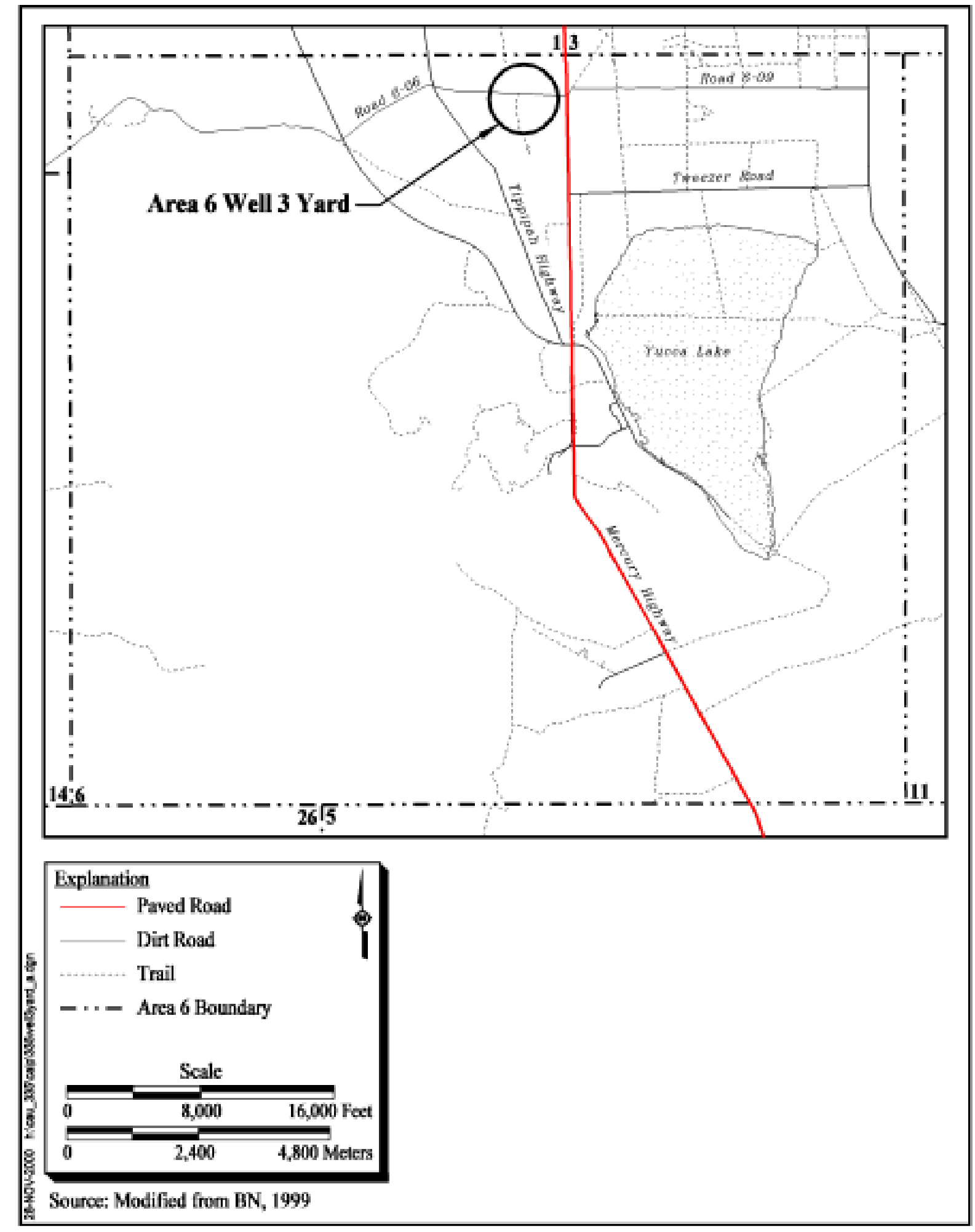

Figure 1-2

Area 6 Well 3 Yard 


\subsection{Purpose}

This CAIP presents a plan to investigate the nature and extent of contaminants of potential concern (COPCs) at CAU 335. The purpose of the investigation described in this CAIP is as follows:

- Identify the presence and nature of COPCs.

- If COPCs are present, determine their vertical and lateral extent in surface and subsurface soils.

- Provide sufficient information and data to determine and evaluate appropriate corrective actions for each CAS.

This CAIP was developed using the U.S. Environmental Protection Agency's (EPA) Data Quality Objectives (DQOs) (EPA, 1994) process to clearly define the goals and set the DQOs for collecting environmental data and to design a data collection program that will satisfy these goals. A DQO scoping meeting was held prior to preparation of this plan. A brief summary of the DQO process is presented in Section 3.4, while a more detailed summary and results are included in Appendix A of this CAIP.

\subsection{Scope}

The scope of this CAIP is to resolve the problem statement identified during the DQO process, which states that potentially hazardous and/or radiological constituents may have been discharged into two of the three CASs that comprise CAU 335, Area 6 Injection Well and Drain Pit. Existing data are sufficient to close CAS 06-20-01 with no further action. Existing data are insufficient to evaluate and select preferred corrective actions for CAS 06-20-02 and CAS 06-23-03. Therefore, the scope of the corrective action investigation for CAU 335 includes the following tasks:

- Select sample locations in likely worst-case areas to increase the level of certainty of finding COPCs, if any.

- Collect surface and subsurface soil samples using drilling methods such as hollow-stem auger or direct-push techniques.

- $\quad$ Field-screen soil samples for volatile organic compounds (VOCs), total petroleum hydrocarbons (TPH), and alpha/beta-emitting radionuclides. 
- Conduct laboratory analyses of environmental soil samples for COPCs identified in Section A.3.0 in accordance with methods listed in Appendix C.

- Investigate piping associated with CAS 06-23-03, Drain Pit, using a combination of visual, video, and electromagnetic surveys. Collect sediment samples in the piping (if possible) and submit for laboratory analyses.

\subsection{CAIP Contents}

Section 1.0 of this CAIP provides an introduction to this project, including the purpose and scope for this corrective action investigation. Section 2.0 provides a site description and operational history. The remainder of the document details the investigation strategy and complies with the following FFACO-required elements:

- Management

- Technical aspects

- Quality assurance

- Health and safety

- Public involvement

- Field sampling

- Waste management

The managerial aspects of this project are discussed in the DOE/NV Project Management Plan (DOE/NV, 1994) and a site-specific Field Management Plan that will be developed prior to field activities. The technical aspects of this CAIP are contained in Section 3.0 and Section 4.0 of this document and in the DQO summary presented in Appendix A. General field and laboratory quality assurance (QA) and quality control (QC) issues, including collection of QC samples, are presented in the Industrial Sites Quality Assurance Project Plan (QAPP) (DOE/NV, 1996b); the methods for field QA/QC are discussed in approved procedures. The general health and safety aspects of this project are discussed in the IT Corporation, Las Vegas (ITLV) Health and Safety Plan (HASP) (IT, 2000) and will be supplemented with a site-specific HASP (SSHASP) written and approved prior to the start of field work. As required by the U.S. Department of Energy (DOE) Integrated Safety Management System (ISMS), these documents outline the requirements for protecting the health and safety of workers and the public, and procedures for the protection of the environment. No CAU-specific public involvement activities are planned at this time; however, an overview of public involvement is documented in the "Public Involvement Plan" in Appendix V of the FFACO. Field sampling activities are discussed in Section 4.0 of this CAIP; waste management issues are discussed in 
Section 5.0. The project schedule and records availability information for this CAIP are discussed in Section 6.0, and Section 7.0 provides a list of project references. 


\subsection{Facility Description}

The following sections provide background information and process knowledge as it relates to the physical setting and operational history of CAU 335. This information was gathered from historical documents, photographs, engineering drawings, site maps, and field visits.

\subsection{Physical Setting}

Corrective Action Unit 335 is located within Area 6 of the NTS (see Figure 1-2). Topographically, Area 6 is located within Yucca Flat, an internal-draining, north-south trending intermontane valley. Yucca Flat is bounded on the north by Quartzite Ridge; on the east by Halfpint Range; on the south by Yucca Lake, Mine Mountain, CP Hills, and Massachusetts Mountain; and on the west by Rainier Mesa, Eleana Range, and Shoshone Mountain. Surficial sediments consist of Quaternary and Tertiary valley fill alluvium derived from the surrounding mountains, which are composed of Paleozoic carbonates and clastics and Tertiary volcanics. The alluvium consists of gravel and sand with intermittent silt beds. These Quaternary/Tertiary alluvial strata are generally less than 1,800 feet (ft) thick, based on well penetrations, and occur within fault-bounded troughs above the underlying Tertiary volcanic section. (IT, 1993)

Area 6 is located in the Ash Meadows Groundwater Basin where groundwater generally moves downward through alluvium and volcanic rocks to a Paleozoic carbonate aquifer. Groundwater generally flows southwest and discharges at the large springs in Ash Meadows, about $25 \mathrm{mi}$ southwest of Mercury (Winograd and Thordarson, 1975). Water Well 3, a water supply well drilled in 1951 and no longer in use, is located about 1,250 ft northwest of the site. The well penetrated 1,800 ft of Tertiary alluvium and in March 1993, a static water level was measured at 1,533 ft below ground surface (bgs) in a reworked tuff unit. (IT, 1993)

The closest active water-supply wells on the NTS include Water Well 4, Water Well 4A, Water Well C, and Water Well C-1. These wells are located in the southeast corner of Area 6, approximately $7 \mathrm{mi}$ southeast and downgradient of CAU 335. Static water levels measured in these wells range from $940.7 \mathrm{ft}$ bgs in Water Well 4 to 1,541.6 ft bgs in Water Well C-1 (DRI, 1996). 


\subsection{Operational History}

The following sections provide the operational history of the CASs that comprise CAU 335.

\subsubsection{CAS 06-20-02, 20-inch Cased Hole}

The Cased Hole is located approximately $10 \mathrm{ft}$ from the northeast corner of Building 6-388, in the southern portion of the Well 3 Yard (Figure 2-1). The site was used for the disposal of used motor oil, wastewater, and debris. On October 2, 1990, the Cased Hole was inspected by Reynolds Electrical \& Engineering Co., Inc. (REECo) and noted to be a 20-inch (in.) diameter steel casing rising approximately $2 \mathrm{ft}$ above grade. Over the next several days, used motor oil, wastewater, and solid debris were removed from the casing. This material was containerized into four 55-gallon (gal) drums and the oil and water were sampled. The drums were staged around the well casing and roped off to discourage further disposal. Historical documents indicate that the drums were removed to the Area 5 HWAS on July 23, 1991 (REECo, 1992). Shipping manifests have not been identified. These drums constitute CAS 06-20-01, Drums; Oil Waste; Spill.

The casing was excavated with a backhoe on July 25, 1991. Field notes indicate the casing was $9 \mathrm{ft}$ long and that the bottom was welded and sealed. The casing was in good condition with no perforations or indication of degradation. During excavation, the surface soil surrounding the casing was noted to be contaminated. Based on visual observation, this contaminated surface soil was segregated from uncontaminated soil excavated from around the rest of the casing (Madsen, 1991). Three soil samples were collected. One sample was collected at the surface ( $0.0-0.5 \mathrm{ft}$ bgs $)$, one sample was collected at $3 \mathrm{ft}$ bgs, and one sample was collected near the bottom of the casing at $8 \mathrm{ft}$ bgs. These samples were discarded due to malfunction of a storage refrigerator. On August 1, 1991, the site was resampled. This time, two soil samples were collected. One sample was collected from the surface $(0.0-0.5 \mathrm{ft} \mathrm{bgs})$ and another sample was collected at $8 \mathrm{ft}$ bgs, from near the bottom of the casing (Clark, 1991). The Cased Hole location was then backfilled, though it is unknown when this occurred or what material was used for backfill. It is unknown what happened to the casing or the segregated surface soil after excavation. The site is currently described as a 5 - $\mathrm{ft}$ diameter, 3-in. high mound of soil, presumably at the former location of the Cased Hole (Figure 2-2). Table 2-1 is a time line that summarizes significant events in the operational history of CAS 06-20-01 and CAS 06-20-02. 


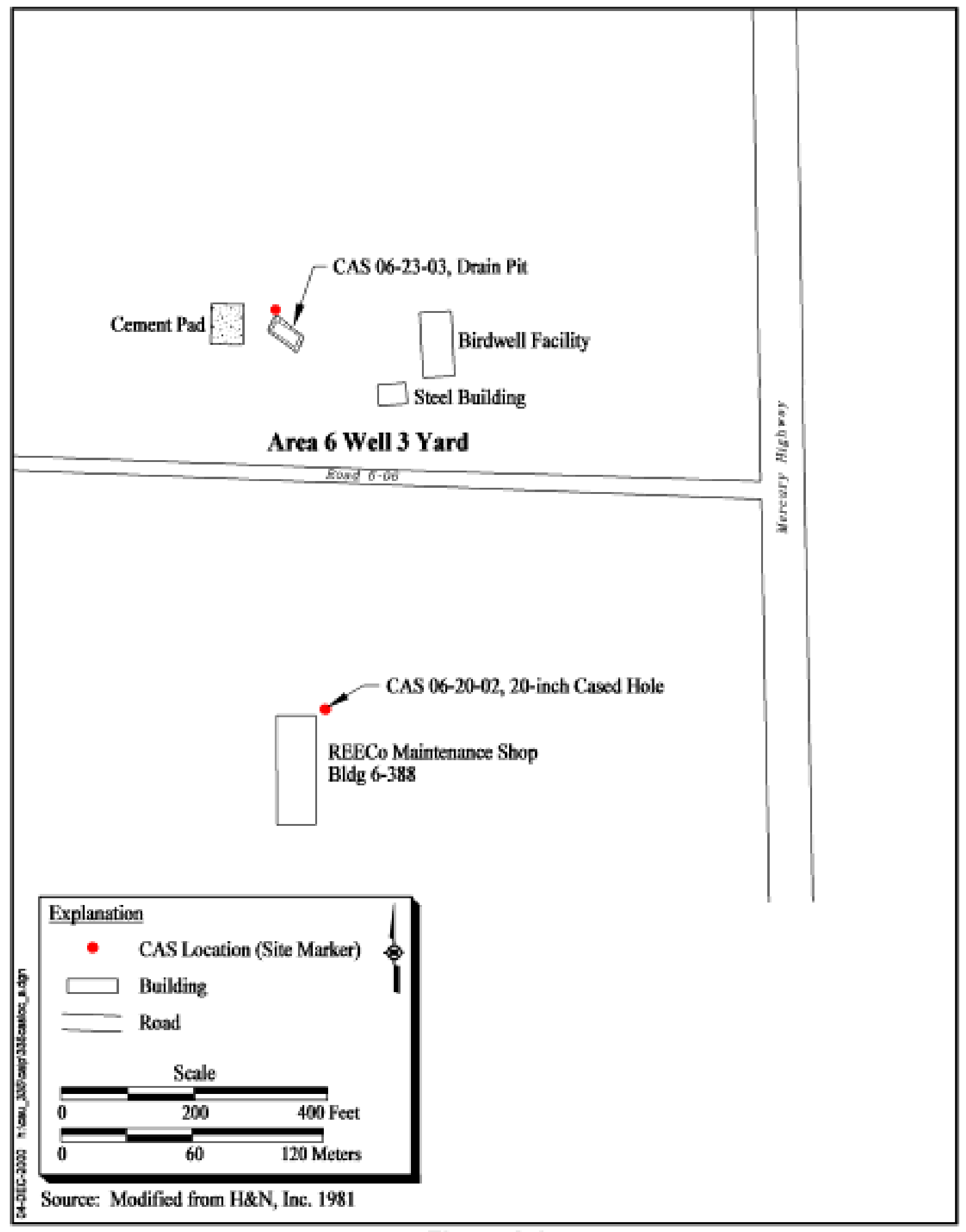

Figure 2-1

Site Location Map, CAS 06-20-02 and CAS 06-23-03 


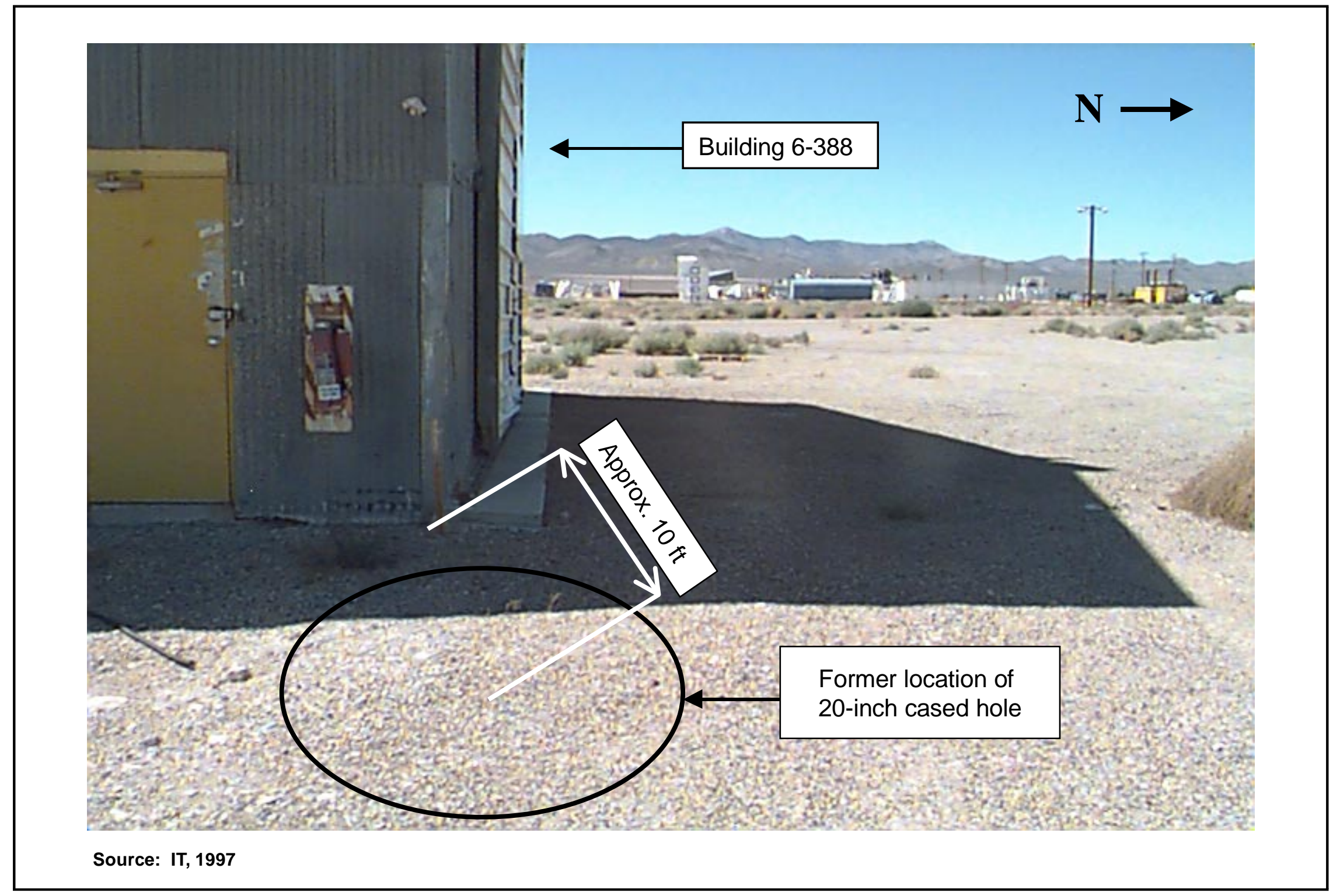

Figure 2-2

Photograph of Former Location of CAS 06-20-02, 20-inch Cased Hole, taken on September 22, 1997 
Table 2-1

Time Line for CAS 06-20-01 and CAS 06-20-02

\begin{tabular}{|c|c|}
\hline Date & Event \\
\hline unknown & 20-in. diameter well casing installed in Well 3 Yard. \\
\hline 10/02/1990 & $\begin{array}{l}\text { DOE/NV requests REECo investigate an accumulation of oil in the Well } 3 \text { Yard. REECo } \\
\text { discovers a } 20 \text {-inch diameter steel casing rising } 2 \mathrm{ft} \text { above grade. }\end{array}$ \\
\hline 10/05/1990 & $\begin{array}{l}\text { REECo removes } 100 \mathrm{gal} \text { of water, } 20 \mathrm{gal} \text { of oil, and solid debris. Waste is containerized in four } \\
55 \text {-gal drums. }\end{array}$ \\
\hline 10/08/1990 & $\begin{array}{l}\text { REECo collects one oil sample and one water sample. Casing covered and drums roped } \\
\text { together. }\end{array}$ \\
\hline 10/22/1990 & $\begin{array}{l}\text { The drums are photographed and documented in Nevada Test Site, Inventory of Abandoned } \\
\text { Facilities and Waste Sites. Site is assigned CAS 06-20-01. }\end{array}$ \\
\hline $11 / 13 / 1990$ & $\begin{array}{l}\text { Oil and water sample analyzed for VOCs, semivolatile organic compounds (SVOCs), } \\
\text { polychlorinated biphenyls (PCBs), Resource Conservation and Recovery Acl (RCRA) metals } \\
\text { and flashpoint (oil sample only). VOCs, SVOCs, and metals detected (see Section 2.5.1). }\end{array}$ \\
\hline 07/23/1991 & Drums (CAS 06-20-01) removed to Area 5 HWAS. No shipping manifests located. \\
\hline 07/25/1991 & $\begin{array}{l}\text { REECo excavates casing. Surface soil surrounding the casing is noted to be contaminated. } \\
\text { Surface soil segregated after excavation. Casing described as } 20 \text {-inch diameter, } 9 \text { - } \mathrm{ft} \text { long, } \\
\text { steel casing in good condition with a sealed base. Three soil samples collected; one from the } \\
\text { surface }(0.0-0.5 \mathrm{ft} \text { bgs), one at } 3 \mathrm{ft} \text { bgs, and one near the base of the casing at } 8 \mathrm{ft} \text { bgs. } \\
\text { Samples discarded due to malfunction of storage refrigerator. }\end{array}$ \\
\hline 08/01/1991 & $\begin{array}{l}\text { REECo resamples soil. Two soil samples are collected; one at the surface }(0.0-0.5 \mathrm{ft} \text { bgs }) \text { and } \\
\text { one near the base of the casing at } 8 \mathrm{ft} \text { bgs. Site is now referenced as CAS 06-20-02, 20-inch } \\
\text { Cased Hole. }\end{array}$ \\
\hline 08/29/1991 & $\begin{array}{l}\text { Soil samples analyzed for VOCs, SVOCs, and TPH as waste oil. TPH is detected in the } \\
\text { surface sample at } 17,000 \text { parts per million (ppm) and in the subsurface sample at } 130 \mathrm{ppm} \text {. } \\
\text { Methylene chloride detected in both samples in trace amounts, but also detected in the } \\
\text { associated trip blank and method blank. See Section } 2.5 .2 \text {. }\end{array}$ \\
\hline unknown & $\begin{array}{l}\text { Hole from the excavated casing is backfilled. Backfill material unknown. Excavated casing is } \\
\text { removed from site. Final disposition of casing is unknown. }\end{array}$ \\
\hline 02/15/1995 & $\begin{array}{l}\text { ITLV site visit. Site described as a small bump in grade approximately } 5 \mathrm{ft} \text { in diameter and } 3 \text { in. } \\
\text { high. No soil stain or odors were noted and no surface manifestation of casing present. }\end{array}$ \\
\hline
\end{tabular}




\subsubsection{CAS 06-23-03, Drain Pit}

The Drain Pit is located in the northern section of the Well 3 Yard, approximately $165 \mathrm{ft}$ north of Road 6-06 (Figure 2-1). It was used to receive effluent from truck washing facilities in the Well 3 Yard. The Drain Pit was operational from 1963 through about 1991, a time span roughly concurrent with underground device testing at the NTS. Cement trucks and geophysical logging trucks were washed in the Well 3 Yard, using two portable steam-cleaners. Halliburton and B.J. Titan had the contract for cementing operations. Halliburton operated from about 1963 through 1983, and B.J. Titan continued cementing services through the early 1990s. The geophysical logging companies, Birdwell and Atlas Wireline, performed downhole logging operations at the NTS. Birdwell operated from about 1963 to 1985, and Atlas Wireline provided logging services from then until the early 1990s.

Cement trucks were washed with a portable steam-cleaner on a concrete pad adjacent to and west of the Drain Pit. The concrete pad was part of a $50-\mathrm{ft}$ by $60-\mathrm{ft}$ metal butler building used by the cement contractors for vehicle maintenance and repair. Effluent flowed from the concrete pad into a shallow drainage ditch that emptied into the Drain Pit. Water was also pumped from tanks through the cement truck pumps and discharged into the Drain Pit. Engineering drawings show that the butler building was removed sometime between 1981 and 1991 (H\&N, 1981; Raytheon Services Nevada, 1991). The concrete pad is still present.

Geophysical logging trucks and tools were washed at two different locations in the Well 3 Yard. Interviews indicate that prior to 1985, geophysical equipment was washed outdoors at an area east of the Drain Pit. The exact location of this wash area is unknown. It is believed that effluent drained into a 2.5-in. diameter steel drain pipe that discharged into the Drain Pit. In 1985, the Birdwell Facility, a 50-ft by 100-ft metal building containing office space and a truck wash bay, was built at a location about $180 \mathrm{ft}$ east of the Drain Pit. Geophysical logging trucks and tools were washed in the truck wash bay with a portable steam-cleaner and effluent was discharged to the Drain Pit through another 2.5-in. diameter, steel drain pipe. The building is still present, but inactive.

The Drain Pit is unpermitted and unlined. It is oblong-shaped and measures $65 \mathrm{ft}$ by $37 \mathrm{ft}$ with an estimated depth of four to six ft (Figure 2-3). A shallow drainage ditch extends from the concrete pad to the northwest side of the Drain Pit. This drainage ditch received effluent from cement truck 


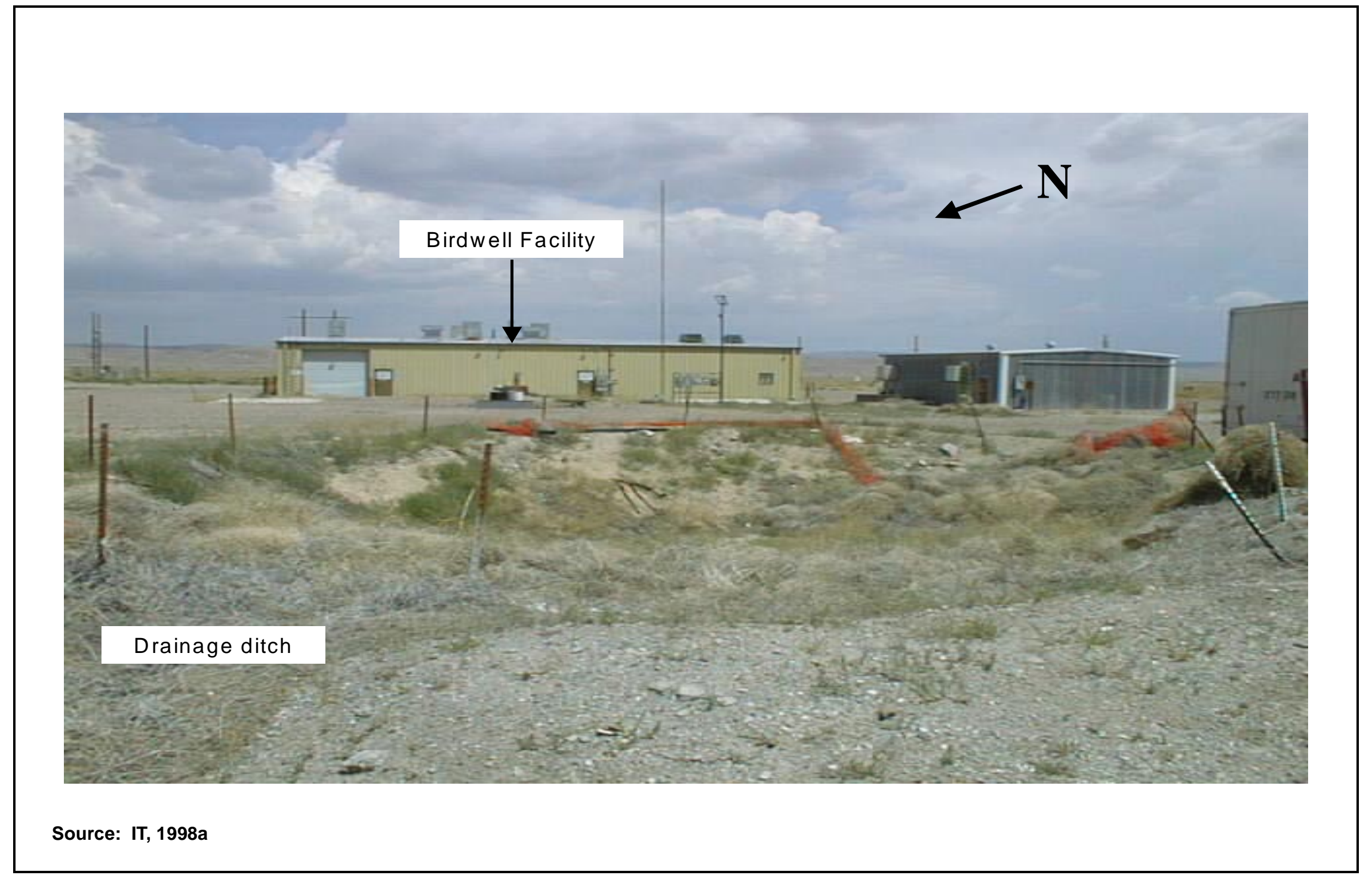

Figure 2-3

Photograph of CAS 06-23-03, Drain Pit, taken on July 21, 1998 
washing operations. A pair of 2.5-in. diameter, steel drain pipes protrude from the east wall of the Drain Pit. It is believed that these pipes drained effluent from washing operations associated with geophysical logging trucks and tools. A single 5-in. diameter, polyvinyl pipe also protrudes from the east wall of the Drain Pit. The source and use of this pipe is unknown. These drain pipes are shown in Figure 2-4. Currently, the Drain Pit is empty of observable waste, though nearly filled with tumbleweeds. In 1998, ITLV field crews identified possible hydrocarbon staining inside and around the outside edge of the Drain Pit, mostly on the south side. Cement washout in the bottom of the Drain Pit was also noted. Later site visits were unable to confirm this staining, and could not confirm the presence of the cement washout due to tumbleweeds in the Drain Pit.

\subsection{Waste Inventory}

Unknown volumes and concentrations of hydrocarbons, chemical compounds, and/or radionuclides may have been released to surface and subsurface soils at two of the three CASs (Cased Hole and Drain Pit) within CAU 335. It is possible (though considered unlikely) that spills from CAS 06-20-01, Drums; Oil Waste; Spill could have contaminated surface soils surrounding the Cased Hole. More than likely, when the oil and wastewater was pumped from the Cased Hole and placed in the drums, some of the waste may have been spilled onto the surface soil. The drums were staged around the Cased Hole for approximately nine months. It is also possible that the drums leaked waste material into the surface soil. Process knowledge of potential waste inventories for each of the CASs is discussed in the following sections.

\subsubsection{CAS 06-20-01, Drums; Oil Waste; Spills}

This CAS consisted of four 55-gal drums that contained material removed from CAS 06-20-02, 20-inch Cased Hole. On October 5, 1990, REECo laborers removed used motor oil, wastewater, and solid debris in the form of oily rags, motor oil containers, paint cans, and oil filters from the Cased Hole. Approximately 20 gal of motor oil were containerized in a 55-gal drum, 100 gal of wastewater was placed in two 55-gal drums, and the solid debris was placed in a fourth drum. On October 8, 1990, REECo laborers attempted to remove the remaining material from the Cased Hole. Most of the debris was removed and placed in the drums, but the sediment was too thick to pump and too thin to shovel. Also on this date, samplers from the REECo Industrial Hygiene Department collected samples of the wastewater and the oil from the drums (Haworth, 1990). Laboratory analysis 


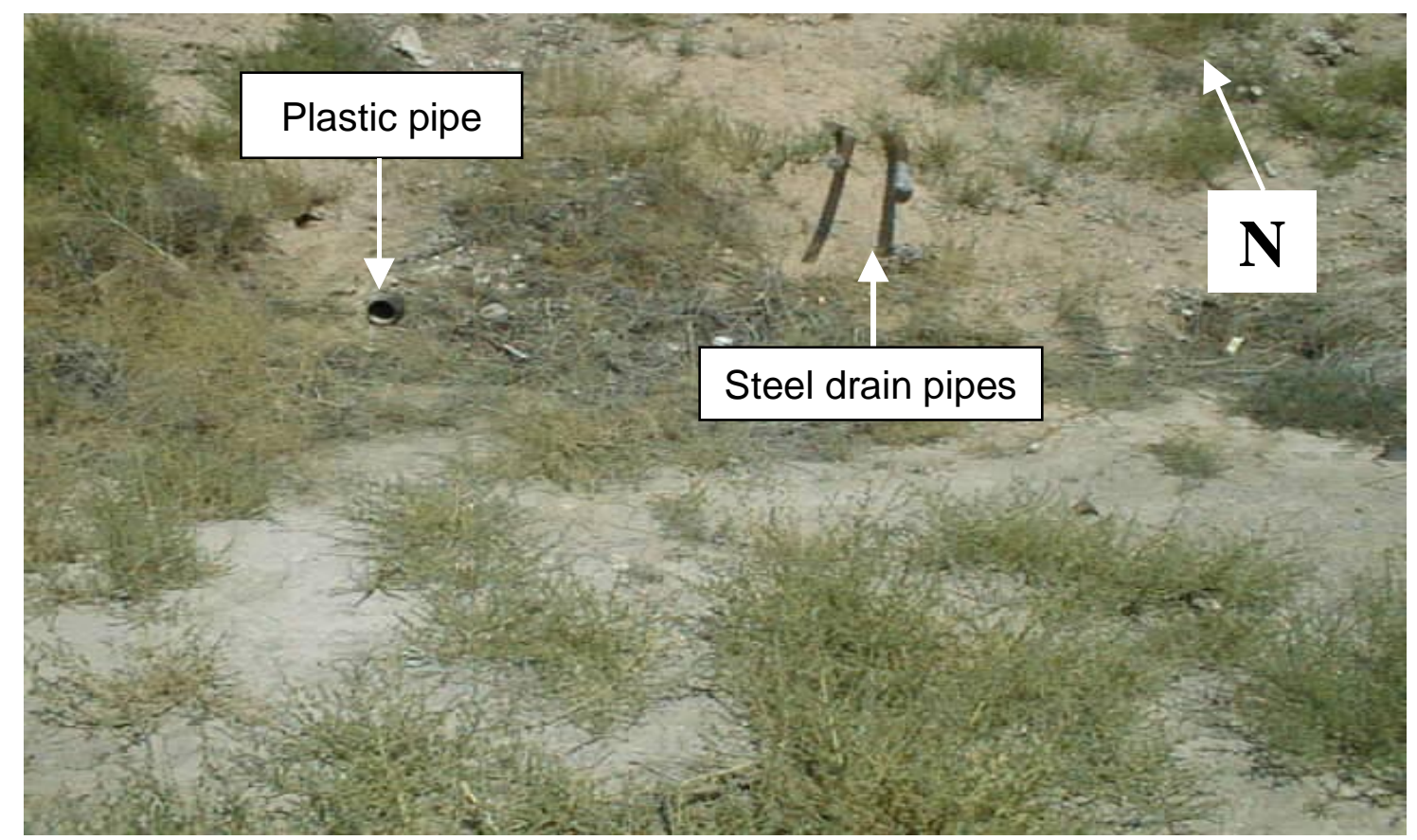

View of northeast wall of drain pit, taken on July 21, 1998 (IT, 1998b)

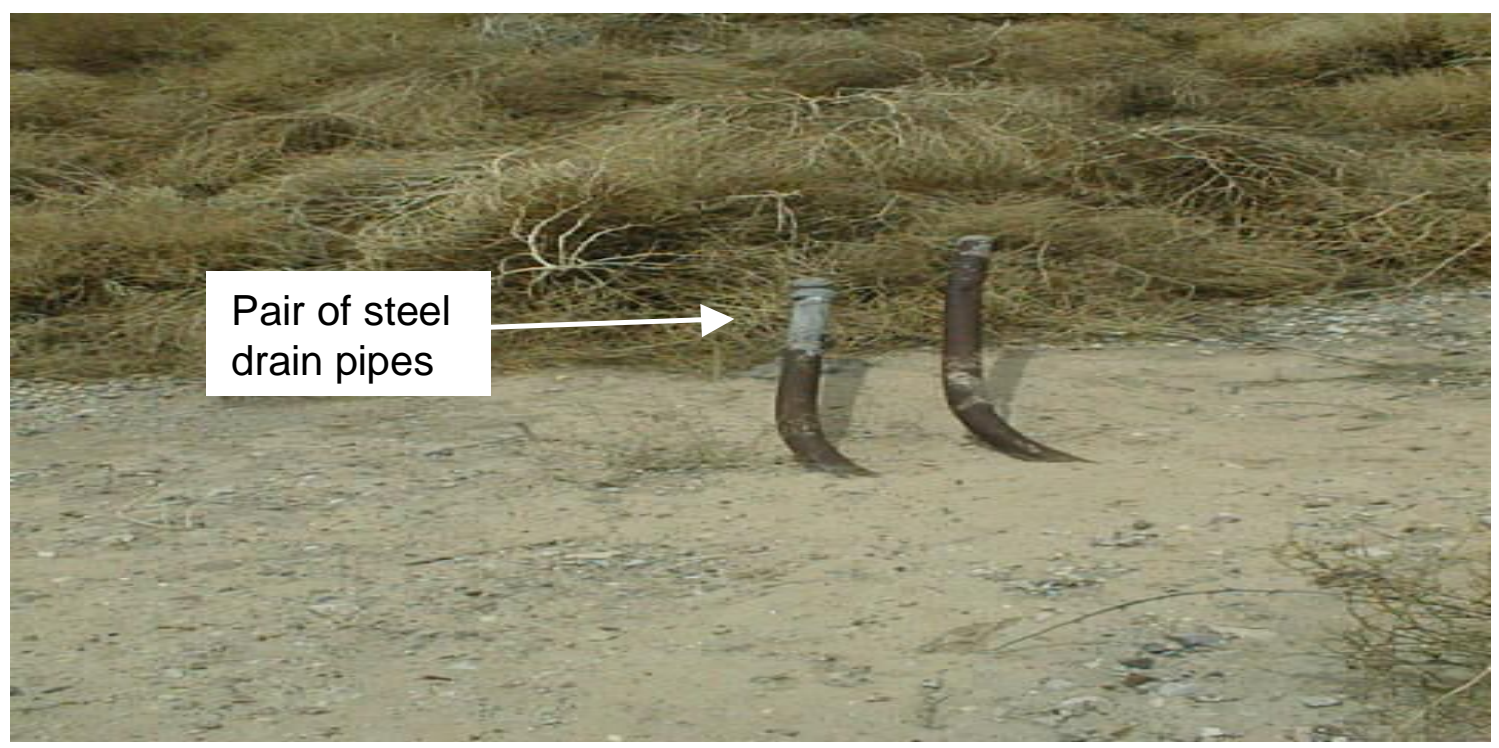

View of pair of steel drain pipes; photo taken from edge of drain pit looking down, taken on July 8, 1999 (IT, 1999)

Figure 2-4

Photograph of Drain Pipes in CAS 06-23-03, Drain Pit, taken on July 21, 1998 and July 8, 1999 
revealed the presence of certain VOCs, semivolatile organic compounds (SVOCs), and Resource Conservation and Recovery Act (RCRA) metals (REECo, 1990) (see Section 2.5.1 for more details). All detected analytes were below action and regulatory levels in place at that time; therefore, the waste was characterized as nonhazardous (Haworth, 1990). The drums were staged around the Cased Hole, and in July of 1991, they were removed to the Area 5 HWAS. The disposition of the drums after this date is unknown.

\subsubsection{CAS 06-20-02, 20-inch Cased Hole}

This CAS was used for the disposal of used motor oil, wastewater, and solid debris. Most of the waste was removed and containerized, as described in Section 2.3.1. The casing was excavated on July 25, 1991. On August 1, 1991, two soil samples from the site were collected and sent for laboratory analysis. Analytical results for these soil samples are discussed in Section 2.5.2.

\subsubsection{CAS 06-23-03, Drain Pit}

The Drain Pit received effluent from truck washing activities conducted in the Well 3 Yard. The effluent may have contained radionuclides, vehicle lubricants, and fuels (gasoline and diesel) (Sanders, 1995). In addition, a cleaning additive known as "Dayton Heavy Duty Vehicle Cleaner" was used in at least one of the steam cleaners. This additive contained sodium tripoly phosphate, ethoxylated alcohols, ethylene glycol monobutyl ether, sodium metasilicate, and sodium dodecylbenzene sulfonate (Hotsy Corporation, 1993). Of these, ethylene glycol monobutyl ether was identified as a COPC during the DQO process based on the fact that this compound has an industrial soils integrated preliminary remediation goal (PRG) of 5,000 milligrams per kilogram (mg/kg) (EPA, 1999). Ethylene glycol monobutyl ether comprised 1 to $5 \%$ by volume of the cleaning additive (Hotsy Corporation, 1993), though it is unknown how much cleaning additive was added to the wash water.

\subsection{Release Information}

Exact quantities of contaminants released at each CAS are unknown. Exposure pathways associated with this CAU, as identified during the DQO process (see Section A.2.0) include oral ingestion, inhalation, and dermal contact (absorption) of COPCs due to inadvertent exposure during sampling and/or remediation activities. Soil is the affected media at this CAU; groundwater impacts are not 
expected due to a groundwater depth of 1,500 ft bgs at this site (IT, 1993). Site-specific release information is discussed in the following sections.

\subsubsection{CAS 06-20-01, Drums; Oil Waste; Spill}

There is no documentation that any material containerized in the drums was released to surface soils surrounding the Cased Hole. The drums were staged around the Cased Hole from October 1990 to July 1991, when they were removed to the Area 5 HWAS. Shortly after that date, surface soil around the Cased Hole was excavated and segregated when the well casing was pulled from the ground. In the event that hazardous contaminants were spilled or released from the drums, any remaining surface soil contamination will be characterized as part of the investigation of CAS 06-20-02, 20-inch Cased Hole.

\subsubsection{CAS 06-20-02, 20-inch Cased Hole}

Discarded motor oil may have contaminated surface soil when the oil was disposed in the Cased Hole. During excavation, it was noted that surface soil surrounding the Cased Hole was contaminated with hydrocarbons (Madsen, 1991). A surface soil sample was described as black with a strong hydrocarbon odor and analytical results of this sample detected TPH as waste oil at 17,000 parts per million (ppm). It is possible that oil and wastewater leaked from the well casing and contaminated subsurface soils. The TPH as waste oil was detected at $130 \mathrm{ppm}$ in a subsurface soil sample, collected near the bottom of the casing (Clark, 1991). However, this concentration is just slightly above the $100 \mathrm{ppm}$ action level (NAC, 2000a), and the noted integrity of the casing and the presence of a welded base suggest it is unlikely that subsurface soils are significantly contaminated.

\subsubsection{CAS 06-23-03, Drain Pit}

Effluent was discharged into the Drain Pit from two steam-cleaning units. Assuming a 30-year operational life of the Drain Pit and that both units were used at full capacity, it is possible that a maximum of 956,400 gal of effluent were discharged. The effluent contained water, cement grout, and possibly vehicle lubricants, oil, and fuels. In addition, the cleaning additive "Dayton Heavy Duty Vehicle Cleaner" was added to at least one of the steam-cleaners (Bingham, 1992). A component of the additive, ethylene glycol monobutyl ether, was identified during the DQO process as a COPC. 
This component comprised 1 to $5 \%$ by volume of the cleaning additive, though it is unknown how much was used during the operational history of the site.

\section{$2.5 \quad$ Investigative Background}

Past investigations at these CASs include liquid and soil sampling (CAS 06-20-01 and CAS 06-20-02), and a magnetic survey conducted at CAS 06-23-03 to locate the source of the steel drain pipes associated with the Drain Pit.

\subsubsection{CAS 06-20-01, Drums; Oil Waste; Spill}

This CAS was first identified in a document entitled Nevada Test Site, Inventory of Inactive and Abandoned Facilities and Waste Sites, which contains a photograph of four drums surrounding a well casing, dated October 22, 1990 (REECo, 1991). An oil and a water sample were collected from the drums on October 8, 1990. Both samples were analyzed for VOCs, SVOCs, polychlorinated biphenyls (PCBs), and RCRA metals. In addition, the oil sample was analyzed for flammability and the water sample was analyzed for total metals. The oil sample tested negative for PCBs and flammability. The water sample tested negative for PCBs and toxic metals (REECo, 1990). Table 2-2 summarizes these analytical results.

\subsubsection{CAS 06-20-02, 20-inch Cased Hole}

This CAS was first identified as "an accumulation of oil in a steel casing" during a REECo site investigation on October 2, 1990. This investigation and subsequent actions are documented in a letter from O. Haworth (REECo) to R. Keller (DOE/NV), dated December 13, 1990 (Haworth, 1990). On July 25, 1991, REECo personnel collected three soil samples during excavation of the casing. One sample was collected at the surface, one at $3 \mathrm{ft}$ bgs, and one near the bottom of the casing at $8 \mathrm{ft}$ bgs. The surface soil sample was black and had a strong hydrocarbon odor; the remaining samples appeared unstained with no odor. These three soil samples were discarded because of a storage refrigerator malfunction and the site was resampled on August 1, 1991. This time, only two soil samples were collected: one from the surface and one at $8 \mathrm{ft}$ bgs. The samples were analyzed for VOCs, SVOCs, and TPH as waste oil. SVOCs were not detected in the samples. Methylene chloride was the only VOC detected. However, this compound was also detected in the trip blank and the laboratory method blank associated with the sampling event (Clark, 1991). The TPH as waste oil was 
Table 2-2

Sampling Results CAS 06-20-01

\begin{tabular}{|c|c|c|}
\hline Analyte & $\begin{array}{l}\text { Oil Sample Results } \\
\qquad(\mu \mathrm{g} / \mathrm{L})\end{array}$ & $\begin{array}{l}\text { Water Sample } \\
\text { Results }(\mu \mathrm{g} / \mathrm{L})\end{array}$ \\
\hline \multicolumn{3}{|c|}{ Organics } \\
\hline acetone & 1,608 & 321 \\
\hline 1,1-dichloroethane & 649 & 127 \\
\hline 1,1,1-trichloroethane & 285 & ND \\
\hline 2-butanone & ND & 119 \\
\hline benzene & 106 & 15 \\
\hline toluene & 1,693 & 90 \\
\hline ethylbenzene & 1,946 & 42 \\
\hline total xylenes & 12,624 & 291 \\
\hline phenol & 23 & 806 \\
\hline benzyl alcohol & ND & 102 \\
\hline 2-methylphenol & ND & 73 \\
\hline 4-methylphenol & ND & 210 \\
\hline naphthalene & ND & 82 \\
\hline 2-methylnaphthalene & ND & 134 \\
\hline \multicolumn{3}{|c|}{ Inorganics } \\
\hline barium & 1,500 & ND \\
\hline lead & 700 & ND \\
\hline
\end{tabular}

Source: Laboratory Analytical Results, Chain-of-Custody Documents, Sample Requests, and Logbook Entries for ER SITES within Areas 1-30 (REECo, 1990).

$\mu \mathrm{g} / \mathrm{L}=$ Micrograms per liter

ND $=$ Not detected 
detected in both soil samples at concentrations of $17,000 \mathrm{mg} / \mathrm{kg}$ in the surface sample and $130 \mathrm{mg} / \mathrm{kg}$ in the subsurface sample. These concentrations exceed the $100 \mathrm{mg} / \mathrm{kg}$ action level (NAC, 2000a). Table 2-3 summarizes these analytical results. There is no historical information on the use of radioactive material at this site and no radiological analytical results have been identified.

Table 2-3

Sampling Results CAS 06-20-02

\begin{tabular}{|c|c|c|c|c||}
\hline Analyte & $\begin{array}{c}\text { Surface Sample } \\
\text { Results (mg/kg) }\end{array}$ & $\begin{array}{c}\text { Subsurface Sample } \\
\text { Results (mg/kg) }\end{array}$ & $\begin{array}{c}\text { Trip Blank Results } \\
(\mathbf{m g} / \mathbf{k g})^{\mathrm{a}}\end{array}$ & $\begin{array}{c}\text { Method Blank } \\
\text { Results (mg/L) }\end{array}$ \\
\hline \hline VOCs & $\mathrm{ND}^{\mathrm{b}}$ & $\mathrm{ND}^{\mathrm{b}}$ & $\mathrm{ND}^{\mathrm{b}}$ & $\mathrm{ND}^{\mathrm{b}}$ \\
\hline SVOCs & $\mathrm{ND}$ & $\mathrm{ND}$ & $\mathrm{NA}$ & $\mathrm{ND}$ \\
\hline $\mathrm{TPH}$ (waste oil) & 17,000 & 130 & $\mathrm{NA}$ & $\mathrm{NA}$ \\
\hline $\begin{array}{c}\text { Methylene } \\
\text { chloride }\end{array}$ & 0.032 & 0.024 & 0.008 & 0.014 \\
\hline
\end{tabular}

${ }^{a}$ Trip blank results originally reported in solid matrix units (kilogram) and not liquid matrix units (liter)

${ }^{\mathrm{b}}$ All except methylene chloride

$\mathrm{mg} / \mathrm{kg}=$ Milligrams per kilogram

$\mathrm{mg} / \mathrm{L}=$ Milligrams per liter

VOCs $=$ Volatile organic compounds

SVOCs = Semivolatile organic compounds

$\mathrm{TPH}=$ Total petroleum hydrocarbons

ND $=$ Not detected

$\mathrm{NA}=$ Not analyzed

\subsubsection{CAS 06-23-03, Drain Pit}

The Environmental Survey Preliminary Report, Nevada Test Site, Mercury, Nevada, dated April 1988, states that due to resource reallocations, the site was eliminated from NTS survey-related sampling and analysis (DOE, 1988). However, the Environmental Survey Action Plan, Nevada Test Site, Mercury, Nevada, dated March 1990 (DOE/NV, 1990), states that the Drain Pit was scheduled for a series of compliance actions, including corrective action, to be completed from December 31, 1988, through December 31, 1991. The action plan states that sampling of the Drain Pit was scheduled for March 1989 to determine if hazardous wastes had been discharged (DOE/NV, 1990). No historical soil sampling has been identified for this CAS.

On June 13, 2000, ITLV field crews attempted to trace the steel drain pipes that protrude from the Drain Pit. A Schondstedt Model GA-52CX Magnetic Locator was used. Results were inconclusive 
and it is believed that the pipes are buried at a depth below the detection capabilities of the instrument. 


\subsection{Objectives}

The DQOs are qualitative and quantitative statements that specify the quality of the data required to support potential corrective action(s) for CAU 335. The DQOs were developed to clearly define the purposes for which environmental data will be used and to design a data collection program that will satisfy these purposes. The formulation of a conceptual site model is an aid to the development of DQOs for the site.

\subsection{Conceptual Site Model}

The conceptual site model defines the expected nature and extent of contamination within CAU 335. The conceptual site model for this CAU is based on assumptions formulated from information presented in Section 2.0 and discussed during the DQO process. The conceptual site model for CAU 335 is presented in Appendix A and is summarized as follows:

- The COPCs, if present, are associated with the disposal of used motor oil and wastewater in the Cased Hole, and effluent discharge from truck washing activities into the Drain Pit.

- Contamination, if present, will be confined laterally within the historical boundaries of the Cased Hole and Drain Pit.

- Contamination, if present, will be confined vertically to $15 \mathrm{ft}$ bgs at the Cased Hole and $10 \mathrm{ft}$ below the bottom of the Drain Pit.

- Radionuclides are not anticipated in the Cased Hole. Radionuclides may be present in the Drain Pit from washing geophysical logging equipment and subsequent effluent discharge.

- The construction, geometry, and source(s) of the drain pipes associated with the Drain Pit are not fully known.

- Exposure pathways are ingestion, inhalation, and dermal contact.

- Groundwater impact is unlikely because the depth to groundwater is extensive (approximately 1,500 ft bgs at Water Well 3, located about 1,250 ft northwest of the site [IT, 1993]) and the environmental conditions at the site (i.e., arid climate, high evaporation) are not conducive to downward migration of COPCs.

- Floodplain studies have not been identified for this CAU. 


\subsection{Contaminants of Potential Concern}

During the DQO process, COPCs for each CAS were identified through process knowledge and site history. The COPCs vary slightly for each CAS included in CAU 335. The following is a listing of the site-specific analytes to be measured to determine the nature and extent of potential contamination at each CAS:

\section{CAS 06-20-02, 20-inch Cased Hole:}

- Total VOCs

- Total SVOCs

- TPH (diesel-range organics)

- Total RCRA metals

\section{CAS 06-23-03, Drain Pit:}

- Total VOCs

- Total SVOCs

- TPH (gasoline- and diesel-range organics)

- Ethylene glycol monobutyl ether

- PCBs

- Total RCRA metals

- Radionuclides (Cesium [Cs]-137; Europium [Eu]-152, Eu-154, Eu-155; Cobalt [Co]-60, isotopic plutonium [Pu]; isotopic uranium [U]; Strontium [Sr]-90)

Tables A.3-1 and A.3-2 in Appendix A list the COPCs to be analyzed for each of these CASs, including field-screening levels (FSLs) and preliminary action levels (PALs). Appendix C provides the analytical requirements which include the minimum reporting limits, analytical methods, precision, and accuracy for all analytes. Specific analyses required for disposal of investigation-derived waste (IDW) are identified in Section 5.0 of this CAIP, Waste Management.

\subsection{Preliminary Action Levels}

The following sections describe the FSLs and PALs for CAU 335. FSLs will be used to determine the presence of contamination and guide the investigation. Laboratory analytical results will be compared to PALs and will guide remediation efforts. FSLs and PALs are provided in Tables A.3-1 and A.3-2 in Appendix A. 


\subsubsection{Field-Screening Levels}

The following FSLs will be used for on-site field-screening methods:

- The VOC headspace screening levels are established at 20 ppm or 2.5 times background, whichever is greater, using a photoionization detector.

- The TPH screening level is defined as $100 \mathrm{ppm}$.

- The radiation (alpha/beta) screening level is defined as the mean surficial-background activity level plus two times the standard deviation of the mean surficial-background activity level.

Concentrations exceeding FSLs will indicate potential contamination at that particular sample location. This information will be documented, and the investigation will continue to delineate the extent of the contamination as necessary. Additionally, these field-screening data will be used to select discretionary samples for laboratory analyses.

\subsubsection{Chemical Preliminary Action Levels}

Off-site laboratory analytical results will be compared to the following PALs to evaluate the need for possible corrective actions:

- NDEP Corrective Action Regulations 445A.2272 (NAC, 2000a); for purposes of this CAIP, Region 9 PRGs for industrial soils are the PALs (EPA, 1999)

- $\quad$ TPH concentrations above the TPH limit of 100 ppm per the Nevada Administrative Code (NAC) 445A.2272 (NAC, 2000a)

Laboratory results and the PALs will be discussed in the Corrective Action Decision Document (CADD). Laboratory results above PALs indicate the presence of COPCs at levels that may require corrective action. Laboratory results below PALs indicate that corrective action is not necessary. Based on the results of this field investigation, the evaluation of potential corrective actions and the justification for a preferred action will be included in the CADD.

\subsubsection{Radiological Preliminary Action Levels}

The PALs for radionuclides are isotope-specific and defined as the maximum concentration for that isotope found in environmental samples taken from undisturbed background locations in the vicinity of the NTS, as presented in McArthur and Miller (1989) and U.S. Ecology and Atlan-Tech (1991). 
The PAL for each isotope will be the maximum concentration of that isotope found in any of the samples taken from the undisturbed background locations described above.

\subsection{DQO Process Discussion}

Details of the DQO process are presented in Appendix A. During the DQO discussions for this CAU, the need for a biased sampling approach was identified which generated a number of sampling locations in potential "worst-case" areas. Due to the potential for surface and subsurface soil contamination, an investigation consisting of surface and subsurface sampling was identified. In addition, the need for visual, video, and/or electromagnetic surveys of the drain pipes associated with the Drain Pit was identified. The COPCs, analytical methods, and reporting limits prescribed through the DQO process are included in Appendix C, along with the precision and accuracy requirements stated in the latest revision of the individual EPA SW-846 methods (EPA, 1996). Resulting data will be evaluated to confirm or refute the conceptual model. 


\subsection{Field Investigation}

This section of the CAIP contains the sampling approach for investigating CAU 335. All sampling activities will be conducted in compliance with the Industrial Sites QAPP (DOE/NV, 1996b) and other applicable, approved procedures and instructions. Quality assurance and quality control requirements for field and laboratory environmental sampling are also contained in the Industrial Sites QAPP and within Appendix C. Data will be collected during field investigations to confirm or refute the conceptual model by determining if COPCs are present in concentrations exceeding the PALs. Field screening will assist the investigation in determining if COPCs are present. Laboratory analyses will be conducted for confirmation and verification of the field-screening results (FSRs).

Field activities will be performed in accordance with the current version of the HASP (IT, 2000) and an approved SSHASP prepared prior to the field effort. As required by the DOE ISMS

(DOE/NV, 2000), these documents outline the requirements for protecting the health and safety of the workers and the public, and the procedures for protecting the environment. The ISMS program requires that site personnel will take every reasonable step to reduce or eliminate the possibility of injury, illness, or accidents, and to protect the environment during all project activities. The following safety issues will be taken into consideration when evaluating the hazards and associated control procedures for field activities discussed in the SSHASP:

- Potential hazards to site personnel and the public including, but not limited to: radionuclides, chemicals (e.g., heavy metals, VOCs, SVOCs, and PCBs), adverse and rapidly changing weather, remote location, and motor vehicle and heavy equipment operations.

- Proper training of all site personnel to recognize and mitigate the anticipated hazards.

- Work controls to reduce or eliminate the hazards including engineering controls, substitution of less hazardous materials, and personal protective equipment (PPE).

- Occupational exposure monitoring to prevent overexposures to hazards such as radionuclides, chemicals, and physical agents (e.g., heat, cold, and high wind).

- Radiological surveying for alpha/beta and gamma emitters to minimize and/or control personnel exposures. Use of the "as low as reasonably achievable" principle when dealing with radiological hazards. 
- Emergency and contingency planning and communications to include medical care and evacuation, decontamination and spill control measures, and appropriate notification of project management.

\subsection{Technical Approach}

Biased surface and subsurface soil sampling will be conducted during the field investigation to determine the presence and the extent of COPCs and whether concentrations exceed PALs for the site. Additional samples may be collected for waste management purposes. Drilling will be the primary investigation technique for this CAU. Visual inspection, video surveys and electromagnetic surveys will be conducted to investigate the drain pipes associated with CAS 06-23-03, Drain Pit. The following activities will be conducted during the site investigation:

- Collect surface and subsurface environmental soil samples from biased locations below and around the Cased Hole and within the Drain Pit.

- Conduct visual, video, and electromagnetic surveys of the drain pipes associated with the Drain Pit. Collect sediment/sludge samples, if possible from within the pipes.

- $\quad$ Field screen soil samples for VOCs, TPH, and radioactivity.

- Collect quality control samples.

- Conduct laboratory analysis for COPCs listed in Section 3.0, discussed in Appendix A, and included in Appendix C.

\subsection{Field Screening}

Field screening provides semiquantitative measurements of soil conditions. Results will be used to guide the investigation and aid in the selection of samples to be submitted for laboratory analysis. Field screening for VOCs and alpha/beta-emitting radionuclides will be conducted at all sampling locations. In addition, all samples collected at the Cased Hole will be field screened for TPH. Field screening for TPH will be conducted at the Drain Pit, if a test kit using nonhazardous extraction solvents can be identified. This approach will minimize the potential for generating mixed waste at the Drain Pit, which is a possible radioactive site.

Field screening for VOCs will utilize the headspace method (photoionization detector and water bath). An Electra alpha/beta scintillator will be used to field screen for alpha/beta-emitting 
radionuclides. Field screening for TPH will use ultraviolet fluorescence (UVF) or other appropriate methods. The FSLs for each method are detailed in Section 3.3.1.

\subsection{Sampling Criteria}

Samples will be selected from each boring for laboratory analysis. The sample collected from the surface interval and the sample with the highest FSR will be sent for analysis. In addition, the sample collected from the first of two consecutive "clean" intervals (i.e., FSRs are lower than FSLs) will be submitted for analysis. Field-screening methods and FSLs are presented in Tables A.3-1 and A.3-2 of Appendix A. The COPCs identified in Section 3.0 of the CAIP will be analyzed in accordance with the requirements in Appendix C.

\subsection{CAS-Specific Investigation Strategy}

The following sections describe investigation strategies specific to the CASs included in CAU 335.

\subsubsection{CAS 06-20-02, 20-inch Cased Hole}

A minimum of four borings will be drilled to investigate the vertical and lateral extent of contamination in the Cased Hole, as shown by Figure 4-1. Additional holes may be drilled at the discretion of the Site Supervisor, based on FSRs.

To investigate the vertical extent of contamination, one boring will be located to penetrate the former location of the Cased Hole. Soil samples will be collected from this boring at the surface and at 5-ft intervals. This boring will be advanced to a minimum depth of $15 \mathrm{ft}$ bgs and continue until FSRs at two consecutive intervals are below FSLs.

To investigate the lateral extent of contamination, three borings will be located in a triangular-pattern around the first boring on approximate 10-ft centers, or at the discretion of the Site Supervisor based on visual observation and FSRs. Samples will be collected at the surface and at 5-ft intervals from these borings. These borings will be advanced to a minimum depth of $15 \mathrm{ft}$ bgs and continue until FSRs at two consecutive intervals are below FSLs. 


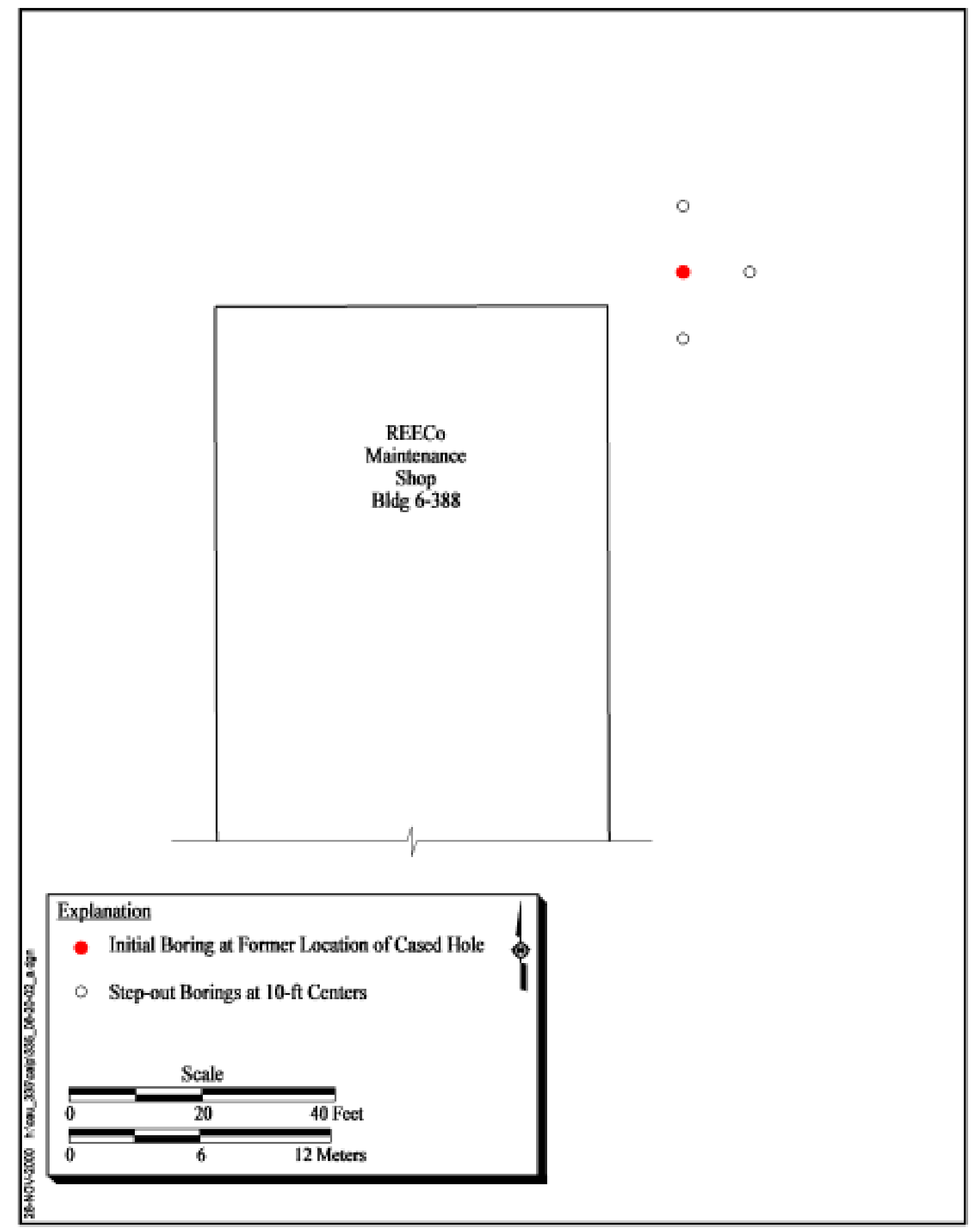

Figure 4-1

Proposed Sample Location Map CAS 06-20-02 


\subsubsection{CAS 06-23-03, Drain Pit}

A minimum of nine borings will be drilled inside and around the Drain Pit, as shown by Figure 4-2. One boring will be located in the low spot in the Drain Pit, based on visual observation. If no low spot is observed, this boring will be located along the southeast wall. A second boring will be centered in the drainage ditch. A third boring will be located under the pair of steel drain pipes and a fourth boring will be located under the plastic pipe.

The remaining five borings will be spaced equidistant along the southern boundary of the Drain Pit, and located approximately $10 \mathrm{ft}$ from the edge of the pit. Additional borings may be drilled at the discretion of the Site Supervisor to adequately characterize the nature and extent of contamination.

Soil samples will be collected from each boring in the Drain Pit at the surface, at $3 \mathrm{ft}$ bgs, then at each 5-ft interval to total depth. The borings will be advanced until FSRs at two consecutive intervals are below FSLs.

\subsubsection{Drain Pipe Investigation}

The drain pipes associated with CAS 06-23-03 Drain Pit will be investigated using a combination of visual inspection, video surveys, EM-31 (or equivalent) surveys, and sediment sampling (if present). The locations of the drain pipes are shown in Figure 4-3.

\section{Plastic Pipe}

The geometry, extent, and contents of the black plastic pipe will be inspected using visual inspection and a video survey:

- The open end of the pipe protruding from the wall of the Drain Pit will be visually inspected for the presence of sediment.

- A video survey will be conducted to locate the upstream end (source) of the pipe and to determine the presence or absence of sediment.

- If visual inspection and/or the video survey locate sufficient quantities of sediment, samples will be collected. If results are inconclusive, the pipe will be breached at a nominal midpoint, and an attempt will be made to collect a sediment sample at that location. Any samples 
(5)

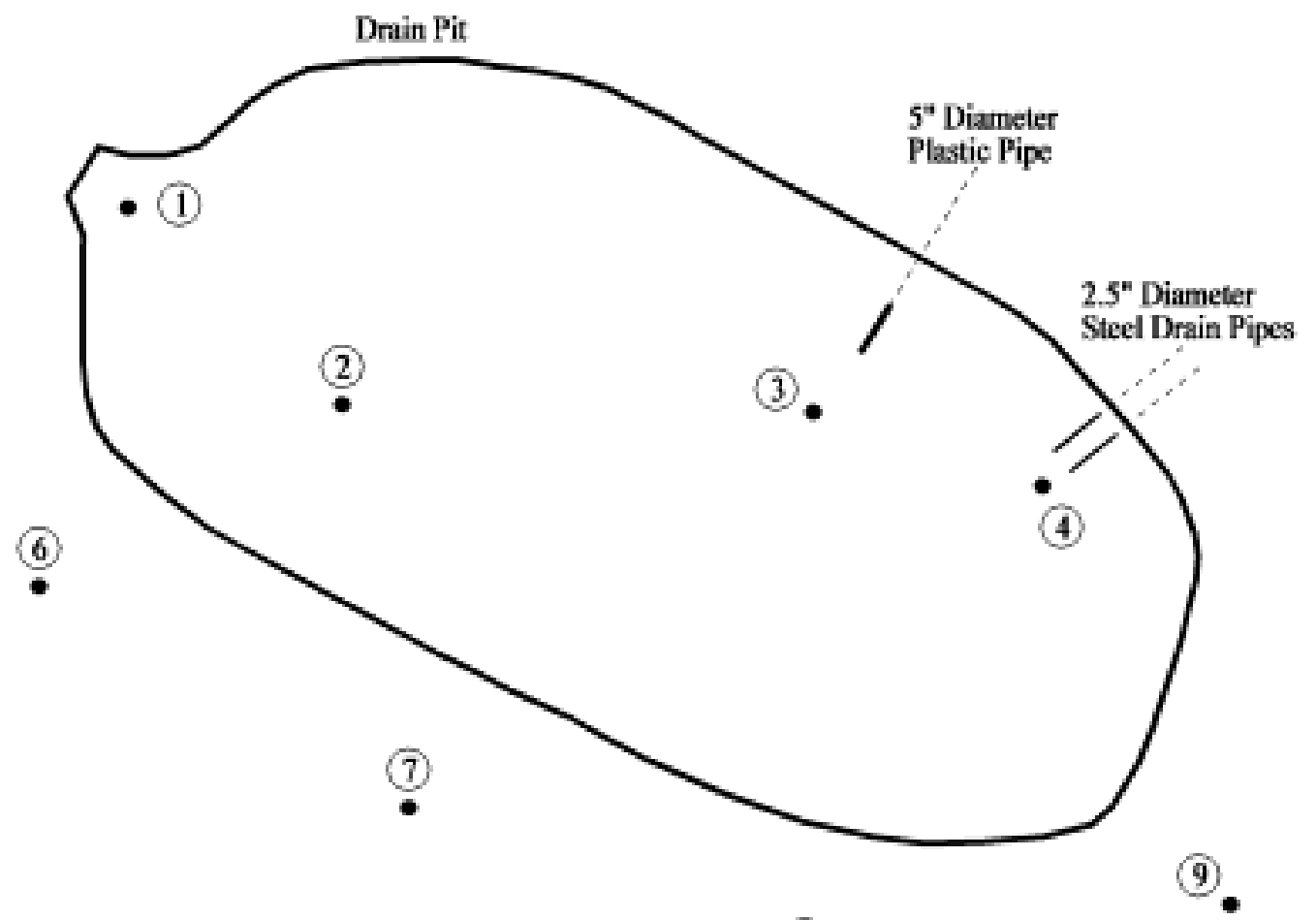

(8)

Figure 4-2

Proposed Sample Location Map CAS 06-23-03

Explanation

(1) Drainage Ditch

(2) Low Point

(3) Under Plastic Pipe

(4) Under Steel Drain Pipes

(5) ... (9) Along Southem Edge

Note of Drain Pit

Sampling Locations are Estimated; Actual Locations will be Field-Verified
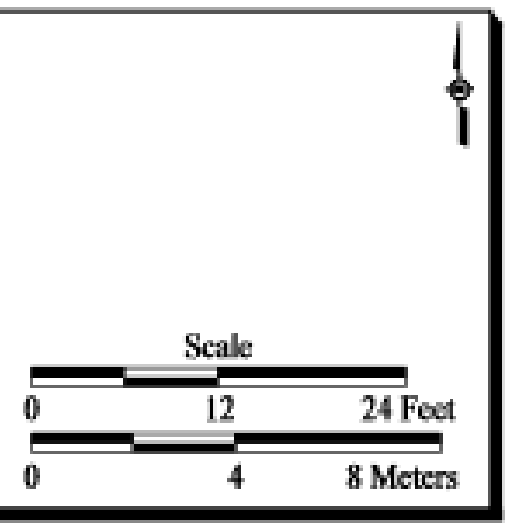

$\frac{6}{2}$ 


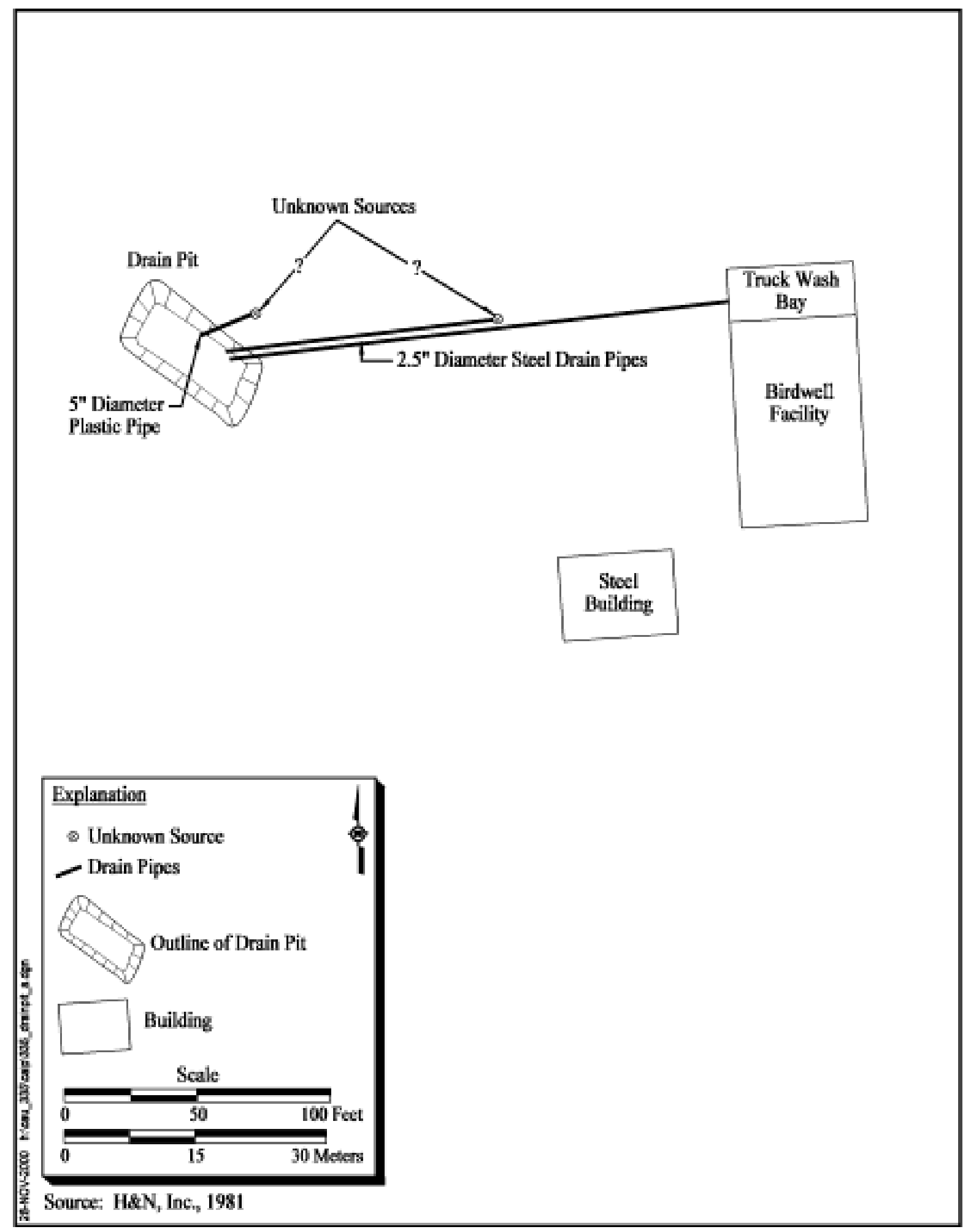

Figure 4-3 Location of Drain Pit Drain Pipes 
collected will be analyzed for the chemical and radiological parameters provided in Section A.3.0.

\section{Steel Drain Pipes}

The geometry, extent, and contents of the steel drain pipes will be inspected using visual inspection, a video survey, and/or an EM-31 (or equivalent) survey.

- The cement plugs will be cut off the ends of the pipes protruding from the wall of the Drain Pit. The ends will be visually inspected for the presence of sediment. In addition, the drain in the truck wash bay in the Birdwell Facility will be inspected for the presence of sediment.

- A video survey will be conducted to locate the upstream ends (sources) of the pipes and determine the presence or absence of sediment.

- An EM-31 survey will be conducted to identify the upstream ends (sources) of the pipes.

- If visual inspection or the video survey locate sufficient quantities of sediment, samples will be collected. If the results are inconclusive, the pipe will be breached at a nominal midpoint, and an attempt will be made to collect a sediment sample at that location. Any samples collected will be analyzed for the chemical and radiological parameters provided in Section A.3.0. 


\subsection{Waste Management}

Management of IDW will be based on regulatory requirements, field observations, process knowledge, and the results of laboratory analysis of the CAU 335 investigation samples. Decontamination activities will be performed according to approved contractor procedures specified in the contractor field sampling instructions and as appropriate for the COPCs identified for CAU 335.

Waste other than soil, such as disposable sampling equipment, PPE, and rinsate, is considered potentially contaminated waste only by virtue of contact with potentially contaminated media. Therefore, sampling and analysis of the IDW, separate from analyses of site investigation samples, may not be necessary. However, rinsate samples will be taken to support waste management activities. The data generated as a result of the site investigation and process knowledge will be used whenever possible to assign the appropriate waste type (i.e., nonhazardous, hazardous, low-level radioactive waste [LLW], or mixed) to the IDW. If generated, IDW will be managed and disposed of in accordance with DOE Orders, U.S. Department of Transportation (DOT) regulations, RCRA regulations, State of Nevada requirements, and agreements and permits between DOE and NDEP.

No process knowledge has been identified to indicate that any release or disposal of any listed hazardous waste occurred. Therefore, if contaminants are identified, they will be considered to be characteristic rather than listed hazardous wastes.

\subsection{Waste Minimization}

Corrective action investigation activities have been planned to minimize IDW generation. To minimize the amount of rinsate generated, decontamination activities will only use the volume of water necessary to decontaminate equipment and personnel. Waste, such as disposable sampling equipment, decontamination rinsate, and PPE will be segregated to the greatest extent possible to minimize the generation of hazardous, radioactive, and/or mixed waste. 


\subsection{Potential Waste Streams}

Potentially contaminated waste generated during the investigation activities will be managed as three waste streams that include:

- Debris and associated trace amounts of soil

- $\quad$ PPE; disposable sampling equipment such as plastic and aluminum foil; and plastic linings from site operations such as decontamination areas, HWAAs, soil staging areas, sample preparation areas, and from beneath drill rigs

- Decontamination rinsate

Waste will be traceable to its source and to individual samples; this information will be recorded in the waste management logbook.

\subsection{Investigation-Derived Waste Management}

Management requirements for nonhazardous (solid/sanitary), hydrocarbon, hazardous, LLW, and mixed waste are discussed in the following sections. The IDW generated will be managed as potentially hazardous waste and potentially radioactive waste until laboratory results indicate either the presence or absence of RCRA regulated constituents and/or radioactive constituents, respectively. Applicable waste management regulations and requirements are listed in Table 5-1.

\subsubsection{Nonhazardous Waste (Solid/Sanitary)}

Sanitary waste not directly associated with sampling activities typically consists of plastic, food, and paper products. This waste will be contained in plastic bags and will be transported to an approved solid waste management unit.

\subsubsection{Hydrocarbon Waste}

The action level for soil contaminated with hydrocarbons is $100 \mathrm{mg} / \mathrm{kg}$ in the State of Nevada (NAC, 2000a). Soils and associated IDW with TPH levels above $100 \mathrm{mg} / \mathrm{kg}$ and containing RCRA-regulated constituents below regulatory limits shall be managed as hydrocarbon waste and disposed of in accordance with all applicable regulations. 
Table 5-1

Waste Management Regulations and Requirements

\begin{tabular}{|c|c|c|}
\hline Waste Type & $\begin{array}{c}\text { Federal } \\
\text { Regulation }\end{array}$ & Additional Requirements \\
\hline Nonhazardous (solid/sanitary) & NA & $\begin{array}{l}\text { NRS } 444.440-444.620^{\mathrm{a}} \\
\text { NAC } 444.570-444.7499^{\mathrm{b}}\end{array}$ \\
\hline Hydrocarbon & NA & NAC 445A.2272 \\
\hline Hazardous & RCRA & $\begin{array}{c}\text { NRS } 459.400-459.600^{d} \\
\text { NAC } 444.850-444.8746^{e} \\
\text { POC }^{f}\end{array}$ \\
\hline Low-Level Radioactive & NA & DOE Orders and NTSWAC \\
\hline Mixed & RCRA & $\begin{array}{l}\text { NTSWAC }^{g} \\
\text { POC }^{f}\end{array}$ \\
\hline
\end{tabular}

${ }^{a}$ Nevada Revised Statutes (NRS, 1998a)

${ }^{\mathrm{b}}$ Nevada Administrative Code (NAC, 2000b)

${ }^{c}$ Nevada Administrative Code (NAC, 2000a)

${ }^{\mathrm{N} N e v a d a}$ Revised Statutes (NRS, 1998b)

${ }^{\mathrm{e}}$ Nevada Administrative Code (NAC, 2000c)

'Performance Objective for the Certification of Nonradioactive Hazardous Waste (BN, 1995)

'Nevada Test Site Waste Acceptance Criteria, Rev. 2 (DOE/NV, 1999)

NA $=$ Not Applicable

\subsubsection{Hazardous Waste}

Suspected hazardous waste will be managed in accordance with RCRA and State of Nevada hazardous waste management regulations and interpreted as follows. Suspected hazardous waste will be placed in 55-gal drums that meet DOT specifications in accordance with 49 Code of Federal Regulations (CFR) 172 (CFR, 1999). Container markings and field records will allow wastes to be traceable back to the source. Additionally, waste may be directly sampled for characterization purposes. The type of container used will be appropriate for the particular waste in storage as specified in 40 CFR 265.172 (CFR, 2000a). No incompatible waste is expected to be generated; however, if incompatible waste is encountered in the field, it will be managed in accordance with 40 CFR 265.177 (CFR, 2000b).

Hazardous waste will be characterized in accordance with the requirements of 40 CFR 261 (CFR, 2000c). Characterization will be based on analytical data, FSRs, process knowledge, or a 
combination thereof. Containers containing wastes pending characterization will be identified with "Hazardous Waste Pending Analysis" markings until their regulatory status can be determined. Depending on the nature and amount of waste generated, waste management control areas may be established, such as a Satellite Accumulation Area (SAA) or a Hazardous Waste Accumulation Area (HWAA).

Suspected hazardous waste will be accumulated as applicable in a HWAA at or near the site of generation for up to 90 days in accordance with 40 CFR 262.34 (CFR, 2000d). Hazardous waste will be shipped to a permitted hazardous waste treatment, storage, or disposal facility before the expiration of the 90 -day storage limit. The waste will be transported by a licensed hazardous waste hauler and accompanied by a Uniform Hazardous Waste Manifest in accordance with DOT shipping requirements. A copy of the manifest will be provided to the NDEP in accordance with State regulatory requirements.

At a minimum, the characterization of hazardous waste (which may contain rinsate) generated during this investigation will comply with the NTS Performance Objective for Certification of Nonradioactive Hazardous Waste (BN, 1995).

\subsubsection{Low-Level Radioactive Waste}

Low-level radioactive waste, if generated, will be managed and characterized in accordance with DOE Orders and the requirements of the Nevada Test Site Waste Acceptance Criteria (NTSWAC) (DOE/NV, 1999). Characterization will be based on analytical data, FSRs, process knowledge, or a combination thereof. Potentially contaminated IDW, such as PPE and disposable sampling equipment, will be placed in clear plastic bags marked with the date and an associated sample location and/or sample number. The plastic bags and any other LLW, such as containerized soil, will be placed in marked packages meeting DOT specifications and locked or fitted with tamper-indicating devices, as specified in 49 CFR 172 (CFR, 1999). The waste will be staged at a designated HWAA/Radioactive Controlled Area (RCA) or a HWAA/Radioactive Materials Area (RMA) pending disposal in accordance with NTSWAC requirements (DOE/NV, 1999). Drums will be marked "Radioactive Material Pending Analysis" until a final waste characterization can be made. 
Rinsate from decontamination activities may be analyzed to determine final disposition. Gross alpha and gross beta analysis may be performed on rinsate samples and the results will be used to determine final disposition. Additionally, the soil characterization results may be applied to the rinsate as part of the determination of final disposition. If rinsate is categorized as LLW on the basis of container-specific sampling or other methods, it will be solidified prior to NTSWAC certification activities.

Any waste to be disposed of in LLW landfills at the NTS will be characterized in accordance with the requirements of the NTSWAC and the contractor-specific waste certification program plan and implementing procedures.

\subsubsection{Mixed Waste}

Mixed waste is a combination of hazardous and radioactive waste. If generated, this waste will be managed in accordance with RCRA (CFR, 2000c) and NAC regulations (NAC, 2000d), as well as DOE requirements for radioactive waste. Where there is a conflict in regulations or requirements, the most stringent shall apply. For example, the 90-day accumulation time limit and weekly inspections per RCRA regulations will be applied to mixed waste even though it is not required for radioactive waste. Conversely, while RCRA does not require documented traceability, the NTSWAC for LLW does; therefore, traceability shall be documented.

In general, mixed waste will be managed in the same manner as hazardous waste, with added mandatory radioactive waste management program requirements. Suspected mixed waste will be managed in accordance with applicable regulations and requirements and marked with the words "Hazardous Waste Pending Analysis," pending characterization and confirmation of its regulatory status. However, once the waste determination is made, or the RCRA 90-day time requirement draws to an end, mixed waste shall be transported via a permitted hazardous waste hauler to the NTS transuranic waste storage pad for storage pending treatment or disposal. Mixed waste with hazardous waste constituents below land disposal restrictions may be disposed of at the Area 5 Radioactive Waste Management Site. Mixed waste not meeting land disposal restrictions will require development of a treatment plan under the requirements of the Mutual Consent Order between DOE and the State of Nevada (NDEP, 1995). 


\subsection{Analysis Required for the Disposal of IDW}

Additional analytical data may be required to characterize the IDW. These analyses will support waste classification to meet the waste acceptance criteria prior to the disposal at on-site NTS and off-site locations. Each of the CASs have been reviewed to ensure that sufficient analyses to support IDW disposal have been planned.

In addition to site characterization analytical data, the following analyses may be requested for waste management decisions:

- At least one sample from each boring at the Cased Hole will be analyzed for gamma spectrometry.

- At least one sample from each CAS will be selected by the Site Supervisor (based on FSRs and/or visual observation) for TCLP VOC, TCLP SVOC, and TCLP RCRA metals analysis.

- Rinsate generated during the investigation may be analyzed for any or all COPCs, based on site characterization analytical data.

- TCLP metals analysis may be requested from any soil sample collected during the investigation. 


\subsection{Duration and Records Availability}

\subsection{Duration}

After submittal of the Final CAIP for CAU 335 to NDEP (FFACO milestone deadline of April 2, 2001), the following is a tentative schedule of activities (in calendar days):

- Day 0: Preparation for field investigation will begin.

- Day 45: The field investigation, including field screening and sampling, will commence. Samples will be shipped to meet laboratory holding times.

- Day 90: The field investigation will be completed. Unvalidated analytical data will be returned from the laboratory.

- Day 120: The quality-assured, analytical sample data will be available for NDEP review.

- The FFACO deadline for the CADD is proposed for December 31, 2001.

\subsection{Records Availability}

This document is available in the DOE public reading rooms located in Las Vegas and Carson City, Nevada, or by contacting the DOE/NV Project Manager. The NDEP maintains the official Administrative Record for all activities conducted under the auspices of the FFACO. 


\subsection{References}

BN, see Bechtel Nevada.

Bechtel Nevada. 1995. Nevada Test Site Performance Objective for Certification of Nonradioactive Hazardous Waste, G-E11/96.01, Rev. 0. Las Vegas, NV.

Bechtel Nevada. 1999. Base map of Nevada Test Site. Las Vegas, NV.

Bingham, F.E., Reynolds Electrical \& Engineering Co., Inc. 1992. Letter to J.D. Stewart (DOE/NV) regarding Additional Information on Steam-Cleaning Operations on the Nevada Test Site (NTS), 28 August. Las Vegas, NV.

CFR, see Code of Federal Regulations.

Clark, G.A., Reynolds Electrical \& Engineering Co., Inc. 1991. Memorandum to D. Madsen (REECo) regarding Sample Analyses Results, 29 August. Las Vegas, NV.

Code of Federal Regulations. 1999. 49 CFR 172, "Hazardous Materials Table, Special Provisions, Hazardous Materials Communications, Emergency Response Information, and Training Requirements." Washington, DC: U.S. Government Printing Office.

Code of Federal Regulations. 2000a. 40 CFR 265.172, "Compatibility of Waste with Containers." Washington, DC: U.S. Government Printing Office.

Code of Federal Regulations. 2000b. 40 CFR 265.177, "Special Requirements for Incompatible Waste." Washington, DC: U.S. Government Printing Office.

Code of Federal Regulations. 2000c. 40 CFR Part 261, "Identification and Listing of Hazardous

Waste." Washington, DC: U.S. Government Printing Office.

Code of Federal Regulations. 2000d. 40 CFR 262.34, "Accumulation Time." Washington, DC:

U.S. Government Printing Office.

DOE, see U.S. Department of Energy.

DOE/NV, see U.S. Department of Energy, Nevada Operations Office.

DRI, see Desert Research Institute.

Desert Research Institute. 1996. Nevada Test Site Water-Supply Wells, DOE/NV/10845--86, Publication No. 45138. Prepared by D. Gillespie, D. Donithan, and P. Seaber. Reno, NV: Water Resources Center. 
EPA, see U.S. Environmental Protection Agency.

FFACO, see Federal Facility Agreement and Consent Order.

Federal Facility Agreement and Consent Order. 1996 (as amended). Agreed to by the State of Nevada, the U.S. Department of Energy, and the U.S. Department of Defense. Las Vegas, NV.

Haworth, O.L., Reynolds Electrical \& Engineering Co., Inc. 1990. Letter to R.C. Keller (DOE/NV) regarding Oil Sump, Building 6-388 (Old Drilling Support Building), Area 6, 13 December. Las Vegas, NV.

H\&N, Inc., see Holmes \& Narver, Inc.

Holmes \& Narver, Inc. 1981. Engineering drawing JS-006-094-C1 titled "Birdwell \& National Cement Facilities Water \& Sewer System Plot Plan, Section \& Detail," 29 April. Las Vegas, NV.

Hotsy Corporation. 1993. Material Safety Data Sheet for "Dayton 5W730 Heavy Duty Vehicle Cleaner," 15 June. Estherville, IA.

IT, see IT Corporation.

IT Corporation. 1993. Recompletion Report for Groundwater Characterization Project (GCP) Water Well 3, DOE/NV/10972-32. Prepared for the U.S. Department of Energy, Nevada Operations Office. Las Vegas, NV.

IT Corporation. 1997. Digital photograph “062002p3” of former location of 20-inch Cased Hole at northeast corner of Building 6-388, NTS Area 6 Well 3 Yard, 22 September. Las Vegas, NV: IT Digital Photograph Database.

IT Corporation. 1998a. Digital photograph “062303p1” of Drain Pit, NTS Area 6 Well 3 Yard, 21 July. Las Vegas, NV: IT Digital Photograph Database.

IT Corporation. 1998b. Digital photograph “062303p2” of piping in Drain Pit, NTS Area 6 Well 3 Yard, NTS, 21 July. Las Vegas, NV: IT Digital Photograph Database.

IT Corporation. 1999. Digital photograph “062303p3” of pair of steel drain pipes in Drain Pit, Area 6 Well 3 Yard, NTS, 8 July. Las Vegas, NV: IT Digital Photograph Database.

IT Corporation. 2000. ITLV Health and Safety Plan, Rev. 0, ITLV 13052--105. Las Vegas, NV.

Madsen, D., Bechtel Nevada. 1991. Field notes entitled “7/25/91 - Well 3 Yard,” 25 July. Mercury, NV. 
McArthur, R.D., and F.L. Miller. 1989. Off-Site Radiation Exposure Review Project (ORERP), Phase II Soil Program, DOE/NV/10384-23, Publication No. 45064. Las Vegas, NV: Desert Research Institute.

NAC, see Nevada Administrative Code.

Nevada Administrative Code. 2000a. NAC 445A.2272, "Contamination of Soil: Establishment of Action Levels." Carson City, NV.

Nevada Administrative Code. 2000b. NAC 444.570 - 444.7499, "Solid Waste Disposal." Carson City, NV.

Nevada Administrative Code. 2000c. NAC 444.850 - 444.8746, "Disposal of Hazardous Waste." Carson City, NV.

Nevada Administrative Code. 2000d. NAC 444, "Sanitation." Carson City, NV: Nevada Division of Environmental Protection.

Nevada Division of Environmental Protection. 1995. "Mutual Consent Agreement Between the State of Nevada and the U.S. Department of Energy for the Storage of Low-Level Land Disposal Restricted Mixed Waste," transmittal from P. Liebendorfer (NDEP) to D. Elle (DOE/NV), 7 June. Carson City, NV.

NRS, see Nevada Revised Statutes.

Nevada Revised Statutes. 1998a. NRS 444.440 - 444.620, "Collection and Disposal of Solid Waste." Carson City, NV.

Nevada Revised Statutes. 1998b. NRS 459.400 - 459.600, "Disposal of Hazardous Waste." Carson City, NV.

Raytheon Services Nevada. 1991. Engineering drawing JS-006-002-C8.1, titled "Nevada Test Site Area 6 Well 3 Yard Map," 13 February. Las Vegas, NV.

REECo, see Reynolds Electrical \& Engineering Co., Inc.

Reynolds Electrical \& Engineering Co., Inc. 1990. Laboratory Analytical Results, Chain-of-Custody Documents, Sample Requests, and Logbook Entries for ER SITES within Areas 1-30, Volume 4. Las Vegas, NV.

Reynolds Electrical \& Engineering Co., Inc. 1991. Nevada Test Site, Inventory of Inactive and Abandoned Facilities and Waste Sites, DOE/NV/10630-18, Volume 2. Prepared for the U.S. Department of Energy, Nevada Operations Office. Las Vegas, NV. 
Reynolds Electrical \& Engineering Co., Inc. 1992. Detailed Site Activity Summary NTS Cleanup and Restoration, 14 May (updated). Prepared for the U.S. Department of Energy, Nevada Operations Office. Las Vegas, NV.

Sanders, P. 1995. Preliminary Ranking and Prioritization-DOE Defense Programs Sites at NTS, Revision 1, 24 January.

U.S. Department of Energy. 1988. Environmental Survey Preliminary Report, Nevada Test Site, Mercury, Nevada, DOE/EH/OEV-15-P. Washington, DC: Environment, Safety and Health, Office of Environmental Audit.

U.S. Department of Energy, Nevada Operations Office. 1990. Environmental Survey Action Plan, Nevada Test Site, Mercury, Nevada. Las Vegas, NV.

U.S. Department of Energy, Nevada Operations Office. 1994. Project Management Plan, Rev. 0. Las Vegas, NV.

U.S. Department of Energy, Nevada Operations Office. 1996a. Final Environmental Impact Statement for the Nevada Test Site and Off-Site Locations in the State of Nevada, DOE/EIS 0243. Las Vegas, NV.

U.S. Department of Energy, Nevada Operations Office. 1996b. Industrial Sites Quality Assurance Project Plan, Nevada Test Site, Nevada, Rev. 1, DOE/NV--372. Las Vegas, NV.

U.S. Department of Energy, Nevada Operations Office. 2000. Safety Management Policy, DOE Order NV P 450.4B. Las Vegas, NV.

U.S. Department of Energy, Nevada Operations Office. 1999. Nevada Test Site Waste Acceptance Criteria (NTSWAC), Rev. 2. Las Vegas, NV.

U.S. Environmental Protection Agency. 1994. Guidance for the Data Quality Objectives Process, EPA QA/G-4. Washington, DC.

U.S. Environmental Protection Agency. 1996. Test Methods for Evaluating Solid Waste, Physical/Chemical Methods, SW-846, Third Edition, CD ROM, PB97-501928GEI (CD-ROM includes revisions to 1986, 1992, and 1994). Washington, DC.

U.S. Environmental Protection Agency. 1999. Memorandum from S.J. Smucker to PRG table mailing list regarding Region 9 Preliminary Remediation Goals (PRGs), 1 October. San Francisco, CA.

U.S. Ecology and Atlan-Tech. 1991. Environmental Monitoring Report for the Proposed Ward Valley, California Low-Level Radioactive Waste (LLRW) Facility. Rosewall, GA. 
Winograd, I.J., and W. Thordarson. 1975. Hydrogeologic and Hydrochemical Framework, South-Central Great Basin, Nevada-California, with Special Reference to the Nevada Test Site, USGS-PP-712-C. Denver, CO: U.S. Geological Survey. 


\section{Appendix A}

\section{Data Quality Objectives Worksheets}




\section{A.1.0 Introduction}

\section{A.1.1 Problem Statement}

Potentially hazardous and/or radiological constituents may have been discharged into two of the three CASs that comprise CAU 335, Area 6 Injection Well and Drain Pit. Used motor oil, potentially contaminated wastewater of unknown origin, and solid debris were disposed into CAS 06-20-02, 20-inch Cased Hole (Haworth, 1990). The TPH as waste oil was detected at 17,000 ppm in a surface soil sample and at $130 \mathrm{ppm}$ in a soil sample collected from the bottom of the Cased Hole at $8 \mathrm{ft}$ bgs (Clark, 1991). Both of these concentrations exceed the TPH action level of 100 ppm (NAC, 2000). Effluent from truck-washing operations was discharged into CAS 06-23-03, Drain Pit. The effluent contained fuels (diesel and gasoline), motor oil, grease, cleaning additives, and possibly radionuclides (DOE, 1988; Sanders, 1995). The Drain Pit has not been sampled so analytical data are not available.

The third CAS in this CAU is CAS 06-20-01, Drums; Oil Waste; Spill. This CAS consisted of four 55-gallon drums containing material pumped from CAS 06-20-02, 20-inch Cased Hole. Historical documents show that the drums were transported to the Area 5 Hazardous Waste Accumulation Site in July 1991 (REECo, 1992). Since the drums are no longer on site, the CAS will be closed with no further action required as detailed in the forthcoming Closure Report for this CAU. Any spills that may have been associated with this CAS will be investigated under CAS 06-20-02, 20-inch Cased Hole.

Existing information about the nature and extent of contamination at the Cased Hole and Drain Pit is insufficient to evaluate and select preferred corrective actions. The CAU 335 investigation will be based on the DQOs developed by representatives of the NDEP and DOE/NV. This investigation will determine if COPCs are present in concentrations exceeding regulatory levels in the soils around the Cased Hole and Drain Pit. If COPCs are detected, the lateral and vertical extent of contamination will be delineated. Data adequate to close the site under State of Nevada regulations, RCRA, and DOE requirements will be collected.

\section{A.1.2 DQO Kickoff Meeting}

Table A.1-1 lists the participants present at the FFACO-required DQO Kickoff Meeting. The goal of the DQO process is to establish the quantity and quality of environmental data required to support 
Table A.1-1

DQO Kickoff Meeting Participants

\begin{tabular}{|l|l|c|}
\hline \multirow{2}{*}{ Participant } & \multirow{2}{*}{ Affiliation } & Meeting Date \\
\cline { 3 - 3 } & & $\begin{array}{c}\text { Kickoff Meeting } \\
07 / 13 / 00\end{array}$ \\
\hline \hline Stacey Alderson & ITLV & $\mathrm{X}$ \\
\hline Clayton Barrow & DOE/NV & $\mathrm{X}$ \\
\hline John Davis & ITLV & $\mathrm{X}$ \\
\hline Cynthia Dutro & ITLV & $\mathrm{X}$ \\
\hline Sylvan Hersh & ITLV & $\mathrm{X}$ \\
\hline Curtis Obi & BN & $\mathrm{X}$ \\
\hline Charles Orchard & ITLV & $\mathrm{X}$ \\
\hline Shannon Parsons-DePry & BN & $\mathrm{X}$ \\
\hline Carrye Putz & ITLV & $\mathrm{X}$ \\
\hline Greg Raab & NDEP & $\mathrm{X}$ \\
\hline Trenton Richards & ITLV & $\mathrm{X}$ \\
\hline Milinka Watson-Garrett & ITLV & $\mathrm{X}$ \\
\hline Jeanne Wightman & ITLV & $\mathrm{X}$ \\
\hline
\end{tabular}

BN - Bechtel Nevada

DOE/NV - U.S. Department of Energy, Nevada Operations Office

ITLV - IT Corporation, Las Vegas

NDEP - Nevada Division of Environmental Protection

corrective action decisions for CAU 335. The process ensures that the information collected will provide sufficient and reliable information to identify, evaluate, and technically defend the chosen corrective action. Unless otherwise required by the results of this DQO and stated in the CAIP, this investigation will adhere to the Industrial Sites QAPP (DOE/NV, 1996). 


\section{A.2.0 Conceptual Model}

Unknown concentrations and volumes of hydrocarbons, chemical constituents, and radionuclides may have been released in surface and subsurface soils at two of the three CASs within CAU 335. These releases resulted from the disposal of used motor oil, potentially contaminated wastewater, and solid debris in a vertically emplaced well casing, CAS 06-20-02, 20-inch Cased Hole. The motor oil and wastewater may have contaminated surface and subsurface soils either during disposal practices or as a result of leaks in the casing. In addition, effluent from truck-washing operations was discharged into an unpermitted and unlined drain pit, CAS 06-23-03. This effluent may have contained hazardous and/or radiological constituents that may have contaminated surface and subsurface soils in the vicinity of the Drain Pit. Piping associated with the Drain Pit may also be contaminated.

Spills may have been associated with four 55-gallon drums (CAS 06-20-01, Drums; Oil Waste; Spill) that were staged around the Cased Hole for approximately nine months. Since the drums were removed to the Area 5 Hazardous Waste Accumulation Site in July 1991, any potential spills associated with the drums will be investigated under CAS 06-20-02, 20-inch Cased Hole. Section 2.0 of the CAIP provides additional information regarding the site, such as the operational history, waste inventories, release information, and investigative backgrounds.

Diagrammatic sketches of CAS 06-20-02, 20-inch Cased Hole, and CAS 06-23-03, Drain Pit, are provided in Figures A.2-1 and A.2-2, respectively. The conceptual model for CAU 335 is provided in Table A.2-1. 


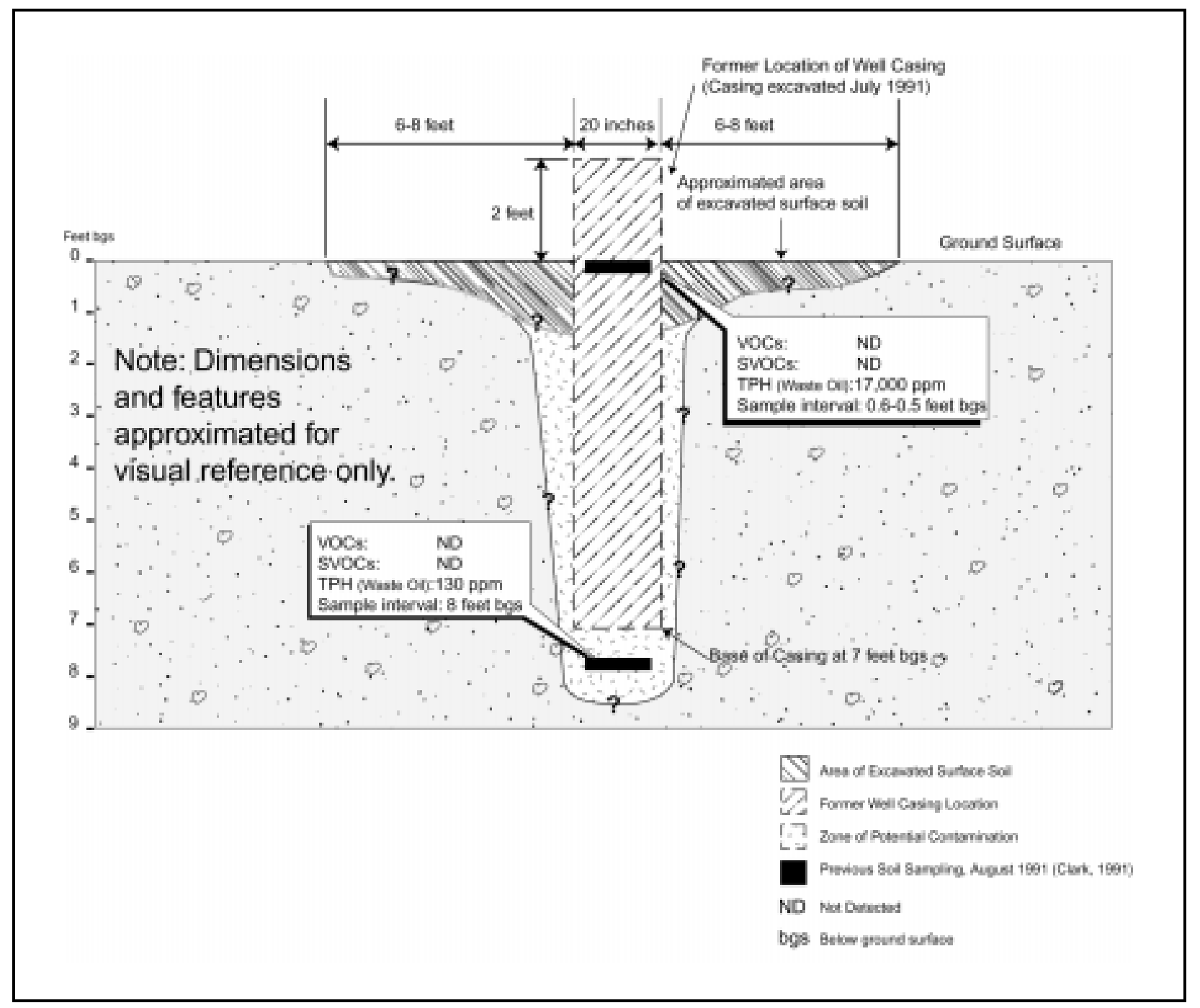

Figure A.2-1

Diagrammatic Sketch of CAS 06-20-02, 20-inch Cased Hole 


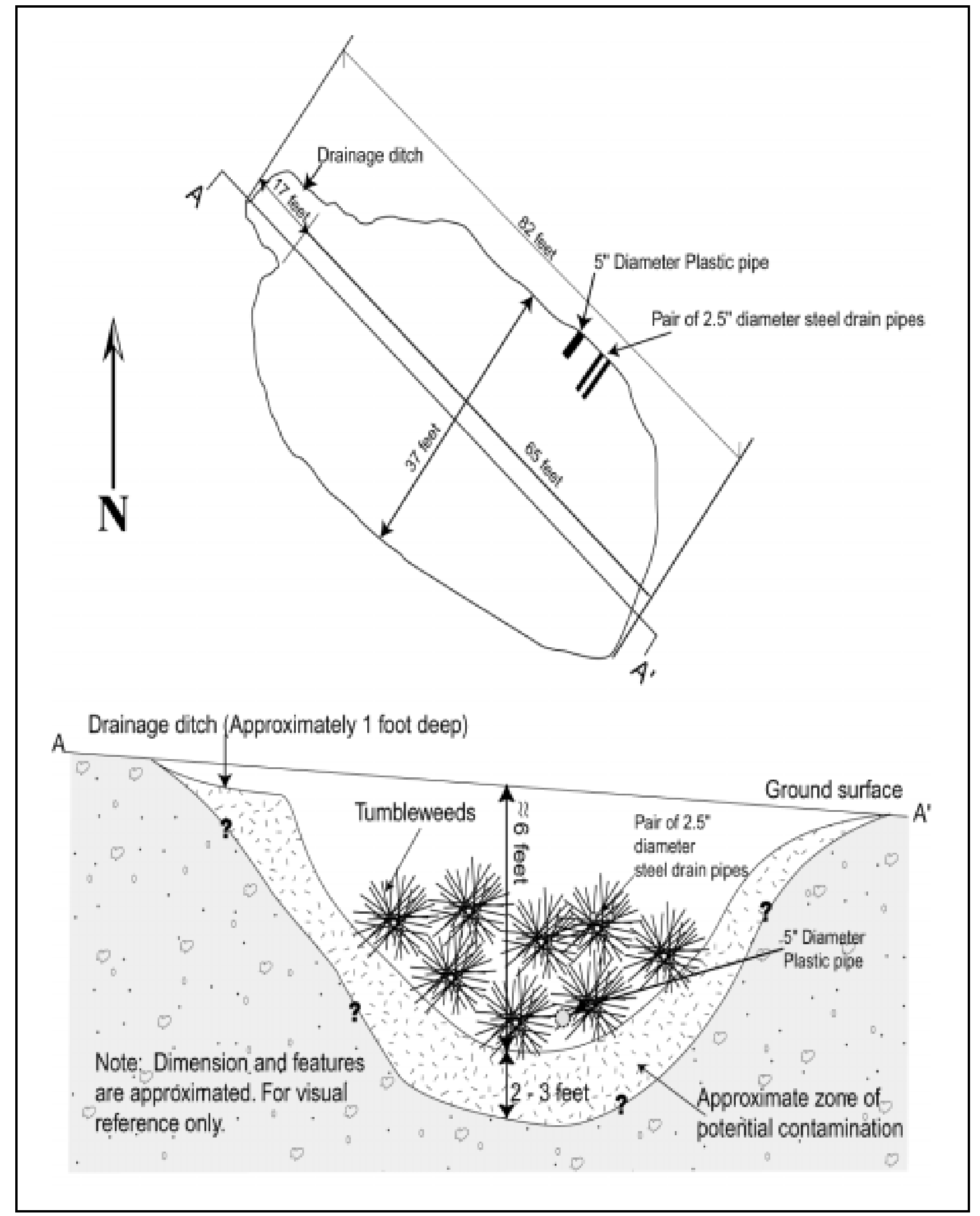

Figure A.2-2

Diagrammatic Sketch of CAS 06-23-03, Drain Pit 
Table A.2-1

Conceptual Model for CAU 335, Area 6 Injection Well and Drain Pit (Page 1 of 4 )

\begin{tabular}{|c|c|c|}
\hline $\begin{array}{l}\text { Conceptual Model } \\
\text { Element }\end{array}$ & Descriptions/Assumptions & Source \\
\hline \multirow{5}{*}{$\begin{array}{l}\text { Drums; Oil Waste; Spill } \\
\qquad(06-20-01)\end{array}$} & $\begin{array}{l}\text { This CAS was located in the Well } 3 \text { Yard, south of } \\
\text { Road 6-06 in Area } 6 \text { of the NTS. It was located } \\
\text { approximately } 10 \mathrm{ft} \text { from the northeast corner of Building } \\
6-388 \text {, occupying the same location as CAS } 06-20-02 \text {. }\end{array}$ & Site investigation \\
\hline & $\begin{array}{l}\text { In October 1990, REECo investigated this location and } \\
\text { found a well casing containing oil, water, and debris } \\
\text { (associated CAS 06-20-02). The contents of the casing } \\
\text { were pumped out and containerized. Approximately } \\
100 \text { gal of water were removed and placed in two 55-gal } \\
\text { drums. Twenty gal of used motor oil were removed and } \\
\text { placed in one 55-gal drum. Assorted solid debris was } \\
\text { removed and placed in one 55-gal drum. }\end{array}$ & Haworth, 1990 \\
\hline & $\begin{array}{l}\text { One oil sample and one water sample were collected. } \\
\text { Laboratory analysis found concentrations of VOCS, } \\
\text { SVOCs, and RCRA metals, all below PALs. }\end{array}$ & $\begin{array}{l}\text { Haworth, } 1990 \\
\text { REECo, } 1990\end{array}$ \\
\hline & $\begin{array}{l}\text { The four drums were removed to the Area } 5 \text { HWAS in } \\
\text { July } 1991 . \text { The drums are not on site. }\end{array}$ & $\begin{array}{l}\text { REECo, } 1992 \\
\text { Site investigation }\end{array}$ \\
\hline & $\begin{array}{l}\text { This CAS will be closed in the Closure Report for this } \\
\text { CAU and will require no further action. }\end{array}$ & NA \\
\hline \multirow{4}{*}{$\begin{array}{l}\text { 20-inch Cased Hole } \\
(06-20-02)\end{array}$} & $\begin{array}{l}\text { This CAS is located in the Well } 3 \text { Yard, south of } \\
\text { Road 6-06 in Area } 6 \text { of the NTS. It is located } \\
\text { approximately } 10 \mathrm{ft} \text { from the northeast corner of Building } \\
6-388 .\end{array}$ & Site investigation \\
\hline & $\begin{array}{l}\text { The Cased Hole was used to dispose used motor oil, } \\
\text { possibly contaminated wastewater, and various solid } \\
\text { debris. The origin of this waste is unknown. It is } \\
\text { unknown when the well casing was installed. }\end{array}$ & Process knowledge \\
\hline & $\begin{array}{l}\text { The Cased Hole was excavated in July } 1991 \text {. It was } \\
\text { described as a } 9 \text {-ft long, } 20 \text {-in. diameter steel casing } \\
\text { with a welded and sealed bottom. When excavated, it } \\
\text { was noted to be in good condition with no evidence of } \\
\text { degradation. Currently, the site is described as a } 5 \text {-ft } \\
\text { diameter, 3-in. high mound of soil with no surface } \\
\text { staining or odor. }\end{array}$ & $\begin{array}{l}\text { Process knowledge } \\
\text { REECo, } 1992 \\
\text { Site investigation }\end{array}$ \\
\hline & $\begin{array}{l}\text { Two soil samples were collected during excavation. } \\
\text { One sample was collected from the surface and was } \\
\text { noted to be black with a strong hydrocarbon odor. The } \\
\text { second sample was collected at } 8 \mathrm{ft} \text { bgs and appeared } \\
\text { clean. Laboratory analysis of these samples found TPH } \\
\text { concentrations of } 17,000 \text { ppm from the surface sample } \\
\text { and } 130 \text { ppm from the subsurface sample. }\end{array}$ & $\begin{array}{l}\text { Process knowledge } \\
\text { Clark, } 1991\end{array}$ \\
\hline
\end{tabular}


Table A.2-1

Conceptual Model for CAU 335, Area 6 Injection Well and Drain Pit (Page 2 of 4 )

\begin{tabular}{|c|c|c|}
\hline $\begin{array}{l}\text { Conceptual Model } \\
\text { Element }\end{array}$ & Descriptions/Assumptions & Source \\
\hline \multirow{6}{*}{$\begin{array}{l}\text { Drain Pit } \\
(06-23-03)\end{array}$} & $\begin{array}{l}\text { This CAS is located in the Well } 3 \text { Yard, north of } \\
\text { Road 6-06 in Area } 6 \text { of the NTS. }\end{array}$ & Site investigation \\
\hline & $\begin{array}{l}\text { The Drain Pit measures } 65 \mathrm{ft} \times 37 \mathrm{ft} \text { and is estimated to } \\
\text { be } 4-6 \mathrm{ft} \text { deep. There is a } 17-\mathrm{ft} \text { long, shallow ditch that } \\
\text { empties into the northwest edge of the pit. }\end{array}$ & Site investigation \\
\hline & $\begin{array}{l}\text { Two } 2.5 \text {-in. diameter steel pipes and a } 5 \text {-in. diameter } \\
\text { plastic pipe extrude from the northeastern wall of the pit. } \\
\text { The source and use of the plastic pipe are unknown. }\end{array}$ & Site investigation \\
\hline & $\begin{array}{l}\text { Liquid effluent from truck washing operations in the Well } \\
3 \text { Yard was discharged into the pit over a } 30 \text {-year period } \\
\text { (approximately early } 1960 \text { s through early } 1990 \text { s). Two } \\
\text { portable steam-cleaners were used to wash the trucks } \\
\text { by two different operators. }\end{array}$ & $\begin{array}{l}\text { Process knowledge } \\
\text { Bingham, } 1992\end{array}$ \\
\hline & $\begin{array}{l}\text { Cement Services (Halliburton and B.J. Titan) washed } \\
\text { cement pumper trucks on a concrete pad adjacent to } \\
\text { and west of the pit. Effluent discharged into the pit via } \\
\text { the shallow drainage ditch. Effluent contained fuels } \\
\text { (diesel and gasoline), grease, oil, and cement grout. }\end{array}$ & DOE/NV, 1990 \\
\hline & $\begin{array}{l}\text { Geophysical Loggers (Birdwell and Atlas Wireline) } \\
\text { washed geophysical logging trucks and geophysical } \\
\text { tools at two different locations. Prior to 1985, it is } \\
\text { believed that washing occurred at an unidentified } \\
\text { outside location east of the pit. Effluent discharged into } \\
\text { the pit through a gravity-fed steel drain pipe, believed to } \\
\text { be one of the steel drain pipes observed in the pit. } \\
\text { After } 1985 \text {, washing occurred at the truck wash bay in } \\
\text { the Birdwell Facility, located approximately } 175 \mathrm{ft} \text { east of } \\
\text { the pit. Effluent discharged into the pit through a } \\
\text { gravity-fed steel drain pipe, believed to be the other } \\
\text { steel drain pipe observed in the pit. } \\
\text { Effluent from these two locations contained fuels (diesel } \\
\text { and gasoline), grease, oil, a cleaning additive containing } \\
\text { solvents and detergents, and possibly radioactive } \\
\text { particles. }\end{array}$ & $\begin{array}{l}\text { la } \\
\text { Engineering drawings } \\
\text { (H\&N, 1981; Stoddard } \\
\text { Building Co., date unknown) } \\
\text { Sanders, 1995 } \\
\text { Hotsy Corporation, } 1993\end{array}$ \\
\hline
\end{tabular}


Table A.2-1

Conceptual Model for CAU 335, Area 6 Injection Well and Drain Pit (Page 3 of 4 )

\begin{tabular}{|c|c|c|}
\hline $\begin{array}{c}\text { Conceptual Model } \\
\text { Element }\end{array}$ & Descriptions/Assumptions & Source \\
\hline \multirow{4}{*}{$\begin{array}{l}\text { Lateral extent of } \\
\text { potential contaminants }\end{array}$} & $\begin{array}{l}\text { Lateral extent of potential contaminants is unknown; } \\
\text { however, subsurface effects are limited by relatively low } \\
\text { contamination concentrations and low volume and/or } \\
\text { low mobility of constituents. }\end{array}$ & Process knowledge \\
\hline & $\begin{array}{l}\text { COPCs may have been redistributed across the surface } \\
\text { of the Well } 3 \text { Yard in the vicinity of the Drain Pit and the } \\
\text { Cased Hole through regrading, vehicle traffic, or } \\
\text { possible remediation activities (i.e., excavation of the } \\
\text { Cased Hole). However, lateral contamination is not } \\
\text { expected to significantly extend past historical } \\
\text { boundaries of each site. }\end{array}$ & Process knowledge \\
\hline & $\begin{array}{l}\text { The radius of lateral contamination is not expected to } \\
\text { extend beyond the borders of the Drain Pit and } \\
\text { connected drainage ditch as no overflow of the pit has } \\
\text { been identified. }\end{array}$ & Process knowledge \\
\hline & $\begin{array}{l}\text { The radius of lateral contamination is not expected to } \\
\text { exceed more than } 10 \mathrm{ft} \text { past the presumed location of } \\
\text { the center of the Cased Hole. }\end{array}$ & $\begin{array}{l}\text { Process knowledge } \\
\text { Site investigation }\end{array}$ \\
\hline \multirow{3}{*}{$\begin{array}{l}\text { Vertical extent of } \\
\text { potential contaminants }\end{array}$} & $\begin{array}{l}\text { The vertical extent of potential contamination is } \\
\text { unknown. Vertical extent will be controlled by surface } \\
\text { and subsurface soil geotechnical parameters, driving } \\
\text { forces, and volume and mobility of contaminants. }\end{array}$ & Process knowledge \\
\hline & $\begin{array}{l}\text { The Drain Pit is unlined, creating the potential for vertical } \\
\text { migration of contaminants. The vertical extent of } \\
\text { contamination is not expected to exceed } 10 \mathrm{ft} \text {. }\end{array}$ & Site investigation \\
\hline & $\begin{array}{l}\text { The well casing was sealed at the bottom and it is } \\
\text { considered unlikely that waste leaked from the casing } \\
\text { and contaminated soil below the bottom of the casing } \\
\text { (approximately } 7 \text { to } 9 \mathrm{ft} \text { ). However, TPH as waste oil } \\
\text { was detected at } 130 \mathrm{ppm} \text { in a subsurface soil sample } \\
\text { collected from } 8 \mathrm{ft} \text { bgs. }\end{array}$ & $\begin{array}{l}\text { REECo, } 1992 \\
\text { Process knowledge } \\
\text { Clark, } 1991\end{array}$ \\
\hline Depth to groundwater & $\begin{array}{l}\text { Groundwater impacts are not expected. The CASs in } \\
\text { this CAU are about } 1,250 \mathrm{ft} \text { southeast of Water Well } 3 \text {. } \\
\text { The depth to groundwater in this well was measured at } \\
\text { approximately } 1,533 \text { feet below the surface in } 1993 . \\
\text { Overburden in the well consists of Tertiary alluvium. }\end{array}$ & IT, 1993 \\
\hline $\begin{array}{l}\text { Physical and practical } \\
\text { constraints }\end{array}$ & $\begin{array}{l}\text { NTS controlled activities may affect ability to } \\
\text { characterize this site. Underground utilities are } \\
\text { expected to exist at the Well } 3 \text { Yard. Adverse weather } \\
\text { conditions and health and safety concerns may affect } \\
\text { this site. Certain health hazards may exist as a result of } \\
\text { cement outwash in the Drain Pit. The site is relatively } \\
\text { remote which may create logistical constraints. }\end{array}$ & $\begin{array}{l}\text { Process knowledge } \\
\text { Site investigation }\end{array}$ \\
\hline
\end{tabular}


Table A.2-1

Conceptual Model for CAU 335, Area 6 Injection Well and Drain Pit (Page 4 of 4 )

\begin{tabular}{|c|l|l|}
\hline $\begin{array}{c}\text { Conceptual Model } \\
\text { Element }\end{array}$ & \multicolumn{1}{|c|}{ Descriptions/Assumptions } & Source \\
\hline \hline Future use & $\begin{array}{l}\text { Future use for the Area 6 Well 3 Yard is restricted to } \\
\text { industrial use. }\end{array}$ & DOE/NV, 2000 \\
\hline Potential exposures & $\begin{array}{l}\text { Oral ingestion, inhalation, or dermal contact (absorption) } \\
\text { of COPCs due to inadvertent exposure during sampling } \\
\text { activities. }\end{array}$ & Process knowledge \\
\hline Waste management & $\begin{array}{l}\text { Waste will be considered characteristic unless contrary } \\
\text { information is discovered during the investigation. }\end{array}$ & Process knowledge \\
\hline
\end{tabular}




\section{A.3.0 Potential Contaminants}

Section 3.0 of the CAIP provides additional information on the COPCs for CAU 335, including PALs and QA/QC requirements. Section 5.0 of the CAIP identifies specific laboratory analyses required for the disposal of IDW. The COPCs vary slightly for each CAS included in CAU 335.

\section{A.3.1 CAS 06-20-02, 20-inch Cased Hole}

The COPCs at CAS 06-20-02, 20-inch Cased Hole, include VOCs, SVOCs, TPH (diesel-range organics), and total RCRA metals that may have been disposed in the Cased Hole. Any contaminants associated with hydrocarbon spills from CAS 06-20-01, Drums; Oil Waste; Spill will be addressed during investigation of the Cased Hole. Some VOCS, SVOCs, and RCRA metals were detected below PALs in oil and water samples collected from the drums (REECo, 1990). Since these liquids may have contributed to soil contamination at the site, VOCS, SVOCs, and RCRA metals will be considered as COPCs associated with CAS 06-20-02.

Process knowledge and previous sampling data identifies the following COPCs for this CAS:

- Total VOCs, total SVOCs, RCRA metals, TPH (diesel-range organics), based upon:

- Some VOCS and SVOCs were detected in oil and water samples collected from associated CAS 06-20-01. However, concentrations did not exceed PALs for these constituents.

- RCRA metals (barium, chromium, and lead) were detected in oil and water samples collected from associated CAS 06-20-01. However, concentrations did not exceed PALs for these constituents.

- $\mathrm{TPH}$ as waste oil was detected at $17,000 \mathrm{mg} / \mathrm{kg}$ in a surface soil sample and at $130 \mathrm{mg} / \mathrm{kg}$ in a subsurface soil sample collected during excavation of the well casing. These concentrations exceed the PRG level of $100 \mathrm{mg} / \mathrm{kg}$ (Clark, 1991).

\section{A.3.2 CAS 06-23-03, Drain Pit}

The COPCs at CAS 06-23-03, Drain Pit, include VOCs, SVOCs, TPH (gasoline- and diesel-range organics), ethylene glycol monobutyl ether, PCBs, total RCRA metals, and radionuclides that may have been discharged into the Drain Pit during truck washing activities. Process knowledge identifies the following COPCs for this CAS: 
- Total VOCs, total SVOCs, total TPH (gasoline- and diesel-range organics), ethylene glycol monobutyl ether, PCBs, RCRA metals, gamma emitters (Cs-137, Eu-152, Eu-154, Eu-155, $\mathrm{Co}-60)$, isotopic $\mathrm{Pu}$, isotopic $\mathrm{U}$, and $\mathrm{Sr}-90$ based upon:

- Potential VOC, SVOC, TPH, PCBs, and RCRA metals contamination from washing trucks. Fuels, grease, motor oil, and hydraulic fluids are compounds that may have leaked from trucks and discharged into the pit in the effluent stream.

- Potential chemical contamination from ethylene glycol monobutyl ether, a compound in the cleaning additive "Dayton Heavy Duty Vehicle Cleaner," that was added to the wash stream.

- Potential radioactive contamination from washing geophysical trucks and downhole geophysical logging tools that were used to log post-test holes. Note: It is assumed that decontamination procedures were followed and the equipment was sufficiently decontaminated prior to washing; therefore, radionuclides in excess of background concentrations are not anticipated.

- Potential contamination associated with truck maintenance in the Well 3 Yard. Specific operations, housekeeping practices, duration of disposal practices, and materials used are unknown.

The presence of contaminants at this CAU will be evaluated through both field screening and laboratory analyses. Samples submitted for laboratory analysis (as defined in Tables A.3-1 and A.3-2) will be analyzed according to the requirements in Appendix $\mathrm{C}$ for the following COPCs:

- Total VOCs

- Total SVOCs

- $\quad$ TPH (gasoline- and diesel-range organics)

- Ethylene glycol monobutyl ether

- $\quad \mathrm{PCBs}$

- Total RCRA metals

- Radionuclides - gamma spectrometry, isotopic $\mathrm{Pu}$, isotopic $\mathrm{U}$, and $\mathrm{Sr}-90$ for samples collected from the Drain Pit. Gamma spectrometry from one sample per boring at the Cased Hole.

Tables A.3-1 and A.3-2 identify the COPCs for each individual CAS. 
Table A.3-1

COPCs for CAS 06-20-02, 20-inch Cased Hole

\begin{tabular}{|c|c|c|c|c|}
\hline cOPCs & Comments & $\begin{array}{l}\text { Field-Screening } \\
\text { Methods }\end{array}$ & $\begin{array}{c}\text { Field-Screening } \\
\text { Levels }\end{array}$ & $\begin{array}{l}\text { Preliminary } \\
\text { Action } \\
\text { Levels }\end{array}$ \\
\hline Total VOCs & $\begin{array}{l}\text { Some VOCs detected in oil and water } \\
\text { samples collected from associated } \\
\text { CAS } 06-20-01 \text {. However, } \\
\text { concentrations were below PALs. }\end{array}$ & Headspace & $\begin{array}{c}20 \mathrm{ppm} \text { or } 2.5 \mathrm{X} \\
\text { background (use } \\
\text { greater value) }\end{array}$ & $\begin{array}{c}\text { PRGs }^{a} \\
\text { NAC } 445 A^{b}\end{array}$ \\
\hline Total SVOCs & $\begin{array}{l}\text { Some SVOCs detected in oil and } \\
\text { water samples collected from } \\
\text { associated CAS } 06-20-01 \text {. However, } \\
\text { concentrations were below PALs. }\end{array}$ & NA & NA & $\begin{array}{c}\text { PRGs }{ }^{a} \\
\text { NAC } 445 A^{b}\end{array}$ \\
\hline $\begin{array}{l}\text { Total RCRA } \\
\text { Metals }\end{array}$ & $\begin{array}{l}\text { Barium, chromium, and lead detected } \\
\text { in oil and water samples collected from } \\
\text { associated CAS } 06-20-01 \text {. However, } \\
\text { concentrations were below PALs. }\end{array}$ & NA & NA & $\begin{array}{c}\text { PRGs }{ }^{a} \\
\text { NAC } 445 A^{b}\end{array}$ \\
\hline $\begin{array}{l}\text { TPH } \\
\text { (diesel-range } \\
\text { organics) }\end{array}$ & $\begin{array}{l}\text { TPH as waste oil was detected at } \\
17,000 \mathrm{ppm} \text { in a surface soil sample } \\
\text { and at } 130 \mathrm{ppm} \text { in a subsurface soil } \\
\text { sample collected during excavation of } \\
\text { the well casing. }\end{array}$ & $\begin{array}{l}\text { Ultraviolet } \\
\text { fluorescence or } \\
\text { equivalent }\end{array}$ & 100 ppm & $\begin{array}{c}100 \text { ppm } \\
\text { NAC } 445 A^{b}\end{array}$ \\
\hline
\end{tabular}

${ }^{a}$ EPA Region 9 Preliminary Remediation Goals (PRGs) (EPA, 1999)

${ }^{\mathrm{b}}$ Nevada Administrative Code (NAC, 1999)

$\mathrm{NA}=$ Not Applicable 
Table A.3-2

COPCs for CAS 06-23-03, Drain Pit

\begin{tabular}{|c|c|c|c|c|}
\hline COPCs & Comments & $\begin{array}{l}\text { Field-Screening } \\
\text { Methods }\end{array}$ & $\begin{array}{l}\text { Field-Screening } \\
\text { Levels }\end{array}$ & Preliminary Action Levels \\
\hline Total VOCs & $\begin{array}{l}\text { Possible occurrence. VOCs as possible } \\
\text { constituents discharged in effluent. }\end{array}$ & Headspace & $\begin{array}{l}20 \text { ppm or } 2.5 X \\
\text { background (use } \\
\text { greater value) }\end{array}$ & $\begin{array}{l}\text { PRGs }{ }^{\mathrm{a}} \\
\mathrm{NAC} 445^{\mathrm{b}}\end{array}$ \\
\hline Total SVOCs & $\begin{array}{l}\text { Possible occurrence. SVOCs as possible } \\
\text { constituents discharged in effluent. }\end{array}$ & NA & NA & $\begin{array}{c}\text { PRGs }{ }^{a} \\
\text { NAC } 445 A^{b}\end{array}$ \\
\hline Total PCBs & $\begin{array}{l}\text { Possible occurrence. SVOCs as possible } \\
\text { constituents discharged in effluent. }\end{array}$ & NA & NA & $\begin{array}{c}\text { PRGs }{ }^{a} \\
\text { NAC } 445 A^{b}\end{array}$ \\
\hline $\begin{array}{l}\text { Ethylene glycol } \\
\text { monobutyl ether }\end{array}$ & $\begin{array}{l}\text { Possible occurrence. This compound is a } \\
\text { constituent of the cleaning additive "Dayton } \\
\text { Heavy Duty Vehicle Cleaner," which was added } \\
\text { to the wash stream. }\end{array}$ & NA & NA & $\begin{array}{l}5,000 \mathrm{ppm}^{\mathrm{a}} \\
\mathrm{NAC} 445 \mathrm{~A}^{\mathrm{b}}\end{array}$ \\
\hline Total RCRA Metals & $\begin{array}{l}\text { Possible occurrence. Total RCRA metals as } \\
\text { possible constituents discharged in effluent. }\end{array}$ & NA & NA & $\begin{array}{c}\text { PRGs }{ }^{a} \\
\text { NAC } 445 A^{b}\end{array}$ \\
\hline $\begin{array}{l}\text { TPH (gasoline- and } \\
\text { diesel-range } \\
\text { organics) }\end{array}$ & $\begin{array}{l}\text { Possible occurrence. TPH as possible } \\
\text { constituents discharged in effluent. }\end{array}$ & NA & NA & $\begin{array}{c}100 \mathrm{ppm} \\
\text { NAC } 445 A^{\mathrm{b}}\end{array}$ \\
\hline $\begin{array}{l}\text { Radionuclides } \\
\text { (Cs-137, Eu-152, } \\
\text { Eu-154, Eu-155, } \\
\text { Co-60, isotopic Pu, } \\
\text { isotopic U, Sr-90) }\end{array}$ & $\begin{array}{l}\text { Not expected since process knowledge } \\
\text { indicates that geophysical logging equipment } \\
\text { was decontaminated to levels below screening } \\
\text { levels before washing. }\end{array}$ & $\begin{array}{l}\text { Electra Alpha/Beta } \\
\text { scintillator }\end{array}$ & $\begin{array}{l}\text { Mean background } \\
\text { activity plus } 2 x \\
\text { standard deviations } \\
\text { for } 20 \text { background } \\
\text { sample readings }\end{array}$ & $\begin{array}{l}\text { The PAL is the maximum } \\
\text { radionuclide concentration of } \\
\text { environmental samples taken from } \\
\text { undisturbed background locations. }\end{array}$ \\
\hline
\end{tabular}

${ }^{a}$ EPA Region 9 Preliminary Remediation Goals (PRGs) (EPA, 1999)

Nevada Administrative Code (NAC, 2000)

NA $=$ Not Applicable 


\section{A.4.0 Decisions and Inputs}

\section{A.4.1 Decisions}

Decisions to be resolved by the investigation include:

- $\quad$ Determine the presence or absence of COPCs.

- If COPCs are present, determine whether COPC concentrations exceed FSLs.

- If COPCs exceed FSLs, determine whether COPC concentrations exceed PALs.

- If COPCs exceed PALs, determine the nature and extent of contamination with enough certainty to develop and evaluate a range of potential corrective actions, including closure in place and clean closure.

\section{A.4.2 Inputs and Strategy}

Inputs are those elements of information used to support the decisions in addressing the identified problem. The strategy provides either the rationale to support the decision or the methodology for collecting data to arrive at the decision. A list of information inputs, existing data, data gaps, and brief strategies are discussed in Table A.4-1. 
Table A.4-1

Decisions, Inputs, and General Strategies

(Page 1 of 2)

\begin{tabular}{|c|c|c|c|c|}
\hline Decision & Input & Existing Data & Data Gap & Strategy \\
\hline \multirow[b]{3}{*}{$\begin{array}{l}\text { Are COPCs present above } \\
\text { PALs at site? }\end{array}$} & $\begin{array}{l}\text { Potential contaminant } \\
\text { identification }\end{array}$ & $\begin{array}{l}\text { Process knowledge of discharge and } \\
\text { disposal practices at Cased Hole and } \\
\text { Drain Pit. } \\
\text { Existing sample data from } 1990 \text { and } \\
1991 \text { (CAS 06-20-01, CAS 06-20-02). }\end{array}$ & Exact COPCs & $\begin{array}{l}\text { Collect soil samples and analyze for } \\
\text { COPCs. }\end{array}$ \\
\hline & $\begin{array}{l}\text { Potential contaminant } \\
\text { concentration }\end{array}$ & $\begin{array}{l}\text { Existing sample data from } 1990 \text { and } \\
1991 \text { (CAS 06-20-01, CAS 06-20-02). }\end{array}$ & $\begin{array}{l}\text { Concentrations of identified } \\
\text { COPCs. }\end{array}$ & $\begin{array}{l}\text { Field-screen soil samples. Compare } \\
\text { FSRs to FSLs. Perform laboratory } \\
\text { analysis of soil samples. Compare results } \\
\text { to PALs. }\end{array}$ \\
\hline & $\begin{array}{l}\text { Potential contaminant } \\
\text { distribution }\end{array}$ & $\begin{array}{l}\text { The vertical extent of COPCs is assumed } \\
\text { to extend no more than } 15 \mathrm{ft} \text { bgs at the } \\
\text { Cased Hole and } 10 \mathrm{ft} \text { bgs at the Drain } \\
\text { Pit. } \\
\text { The lateral extent of COPCs is assumed } \\
\text { to be limited to historical boundaries of } \\
\text { the Cased Hole and Drain Pit. } \\
\text { Cased Hole: Location surmised. } \\
\text { Well casing unperforated and sealed at } \\
\text { base; potential for vertical contamination } \\
\text { unlikely. Assume most or all } \\
\text { contaminated surface soil was removed } \\
\text { during excavation. } \\
\text { Drain Pit: Location known. Assume } \\
\text { homogenous spread of effluent within the } \\
\text { Drain Pit. Possible concentrations of } \\
\text { contaminants in drainage ditch, at low } \\
\text { point, and below discharge pipes. No } \\
\text { record of effluent overflow. } \\
\text { Drain Pit piping: Source and use of steel } \\
\text { drain pipes known or surmised. }\end{array}$ & $\begin{array}{l}\text { Vertical and lateral extent of } \\
\text { COPCs at Cased Hole and Drain } \\
\text { Pit. } \\
\text { Exact source of one of the steel } \\
\text { drain pipes is unknown. Source } \\
\text { and use of plastic pipe is unknown. } \\
\text { Contents of pipes are unknown. }\end{array}$ & $\begin{array}{l}\text { Collect soil samples from biased locations } \\
\text { to characterize lateral and vertical extent } \\
\text { of contamination. Submit soil samples for } \\
\text { analysis from surface interval, interval with } \\
\text { the highest FSR, and the first two } \\
\text { consecutive clean intervals (FSRs < } \\
\text { FSLs). } \\
\text { Add step-out sampling locations, based on } \\
\text { FSRs and laboratory results, to } \\
\text { characterize lateral extent of } \\
\text { contamination. } \\
\text { Collect additional samples from planned } \\
\text { locations, based on FSRs, to characterize } \\
\text { vertical extent of contamination. } \\
\text { Conduct visual, video, and } \\
\text { electromagnetic surveys of drain pipes to } \\
\text { establish geometry and contents. Collect } \\
\text { sediment samples, if present, and analyze } \\
\text { for same COPC suite as Drain Pit } \\
\text { samples. }\end{array}$ \\
\hline
\end{tabular}


Table A.4-1

Decisions, Inputs, and General Strategies

(Page 2 of 2)

\begin{tabular}{|c|c|c|c|c|}
\hline Decision & Input & Existing Data & Data Gap & Strategy \\
\hline \multirow{2}{*}{$\begin{array}{l}\text { Are potential } \\
\text { contaminants migrating? }\end{array}$} & Meteorologic data & $\begin{array}{l}\text { The NTS and Yucca Mountain Site } \\
\text { Characterization Project data on annual } \\
\text { precipitation, evapotranspiration, and } \\
\text { weather. (Meyers and Nordenson, 1962) }\end{array}$ & $\begin{array}{l}\text { None. Sufficient information } \\
\text { available. }\end{array}$ & $\begin{array}{l}\text { No site-specific meteorological data will be } \\
\text { collected; general weather conditions are } \\
\text { noted on daily field notes. }\end{array}$ \\
\hline & Geologic/hydrologic data & $\begin{array}{l}\text { Specific geologic/hydrologic } \\
\text { characteristics of the site. }\end{array}$ & $\begin{array}{l}\text { Existence and characteristics of } \\
\text { differing permeability zones. }\end{array}$ & $\begin{array}{l}\text { Assume mainly near-surface (to } 15 \mathrm{ft} \text { bgs) } \\
\text { investigation. General soil and alluvial } \\
\text { characteristics will be noted on sample } \\
\text { collection log. }\end{array}$ \\
\hline \multirow{3}{*}{$\begin{array}{l}\text { Are data sufficient to } \\
\text { support closure options? }\end{array}$} & No further action & $\begin{array}{l}\text { Historical evidence and current site } \\
\text { conditions show that the drums of CAS } \\
06-20-01 \text { are no longer present. Any } \\
\text { spills associated with this CAS will be } \\
\text { investigated under CAS } 06-20-02 \text {. } \\
\text { Historical evidence that contaminants } \\
\text { were released to environment at } \\
\text { remaining CASs. }\end{array}$ & $\begin{array}{l}\text { NA for CAS 06-20-01 } \\
\text { Insufficient evidence from } \\
\text { remaining CASs to proceed without } \\
\text { investigation. } \\
\text { Presence, concentration, and } \\
\text { extent of COPCs at remaining } \\
\text { CASs. }\end{array}$ & $\begin{array}{l}\text { Include CAS 06-20-01 in the Closure } \\
\text { Report for this CAU. } \\
\text { Collect field and laboratory samples at } \\
\text { remaining CASs and compare results to } \\
\text { FSLs and PALs, respectively. If no } \\
\text { COPCs are above PALs, prepare } \\
\text { CADD/Closure Report. }\end{array}$ \\
\hline & Closure in place & $\begin{array}{l}\text { Assume industrial soil PRG per NAC } \\
445 \mathrm{~A} \text { (NAC, 2000); assume } 100 \mathrm{ppm} \text { for } \\
\text { TPH per NAC 445A; assume } \\
\text { radionuclide concentrations are in the } \\
\text { range of background concentrations. }\end{array}$ & $\begin{array}{l}\text { Presence of regulated COPCs. } \\
\text { Concentrations above PALs. }\end{array}$ & \multirow{2}{*}{$\begin{array}{l}\text { Collect field and laboratory samples and } \\
\text { compare results to FSLs and PALs, } \\
\text { respectively. If no COPCs are above } \\
\text { PALs, prepare CADD/Closure Report; } \\
\text { otherwise prepare CADD. }\end{array}$} \\
\hline & $\begin{array}{l}\text { Clean closure by } \\
\text { contaminant removal }\end{array}$ & $\begin{array}{l}\text { Assume industrial soil PRG per NAC } \\
\text { 445A (NAC, 2000); assume } 100 \mathrm{ppm} \text { for } \\
\text { TPH per NAC 445A; assume } \\
\text { radionuclide concentrations are in the } \\
\text { range of background concentrations. }\end{array}$ & $\begin{array}{l}\text { Presence, concentration, and } \\
\text { extent of COPCs. } \\
\text { Volume of contaminated material } \\
\text { above PALs. }\end{array}$ & \\
\hline
\end{tabular}




\section{A.5.0 Investigation Strategy}

Biased surface and subsurface soil sampling will be conducted during the field investigation to determine the presence and the extent of COPCs and whether concentrations exceed PALs for the site. Additional samples may be collected for waste management purposes. Drilling will be the primary investigation technique for this CAU. Visual inspection, video surveys, and electromagnetic surveys will be conducted to investigate the drain pipes associated with CAS 06-23-03, Drain Pit.

Samples will be selected from each boring for laboratory analysis. The sample collected from the surface interval and the sample with the highest FSR will be sent for analysis. In addition, the sample collected from the first of two consecutive "clean" intervals (i.e., FSRs are lower than FSLs) will be submitted for analysis. Field-screening methods and field-screening levels are presented in Tables A.3-1 and A.3-2. Samples will be analyzed for COPCs identified in Section 3.0 of the CAIP in accordance with the requirements in Appendix C.

Environmental soil samples will be field-screened to guide additional drilling or sampling, as appropriate, to guide sample selection for laboratory analysis, to assist in waste management decisions, and to provide health and safety measures. All samples will be field screened for VOCs using a photoionization detector, and radioactivity using an Electra alpha/beta scintillator or equivalent. In addition, samples collected from the Cased Hole will be field screened for TPH using ultraviolet fluorescence or other appropriate methods. Field screening for TPH will be conducted at the Drain Pit, if a test kit using nonhazardous extraction solvents can be identified. This approach will minimize the potential for generating mixed waste at the Drain Pit, which is a possible radioactive site.

\section{A.5.1 CAS 06-20-02, 20-inch Cased Hole}

A minimum of four borings will be drilled to investigate the vertical and lateral extent of contamination in the Cased Hole. Additional holes may be drilled at the discretion of the Site Supervisor, based on FSRs.

To investigate the vertical extent of contamination, one boring will be located to penetrate the former location of the Cased Hole. Soil samples will be collected from this boring at the surface and at 5-ft 
intervals. These borings will be advanced to a minimum depth of $15 \mathrm{ft}$ bgs and continue until FSRs at two consecutive intervals are below FSLs.

To investigate the lateral extent of contamination, three borings will be located in a triangular pattern around the first boring on approximate 10-ft centers, or at the discretion of the Site Supervisor, based on visual observation and FSRs. Samples will be collected at the surface and at 5-ft intervals. These borings will be advanced to a minimum depth of $15 \mathrm{ft}$ bgs and continue until FSRs at two consecutive intervals are below FSLs.

\section{A.5.2 CAS 06-23-03, Drain Pit}

A minimum of nine borings will be drilled inside and around the Drain Pit. The first boring will be located in the low spot in the Drain Pit, based on visual observation. If no low spot is observed, this boring will be located along the southeast wall. A second boring will be centered in the drainage ditch. A third boring will be located under the pair of steel drain pipes and a fourth boring will be located under the plastic pipe.

The remaining five borings will be spaced equidistant along the southern boundary of the Drain Pit, and located approximately $10 \mathrm{ft}$ from the edge of the pit. Additional borings may be drilled at the discretion of the Site Supervisor to adequately characterize the nature and extent of contamination.

Soil samples will be collected from each Drain Pit boring at the surface, at $3 \mathrm{ft}$ bgs, then at each 5 - $\mathrm{ft}$ interval to total depth. These borings will be advanced until FSRs at two consecutive intervals are below FSLs.

\section{A.5.3 Drain Pipe Investigation}

The drain pipes associated with CAS 06-23-03, Drain Pit, will be investigated using a combination of visual inspection, video surveys, EM-31 (or equivalent) surveys, and sediment sampling, if possible.

\section{A.5.3.1 Plastic Pipe}

The geometry, extent, and contents of the black plastic pipe will be inspected using visual inspection and a video survey:

- The open end of the pipe protruding from the wall of the drain pit will be visually inspected for the presence of sediment. 
- A video survey will be conducted to locate the upstream end of the pipe and to determine the presence or absence of sediment.

- If visual inspection and/or the video survey locate sufficient quantities of sediment, samples will be collected. If results are inconclusive, the pipe will be breached at a nominal midpoint, and an attempt will be made to collect a sediment sample at that location. Any samples collected will be analyzed for the chemical and radiological parameters provided in Section A.3.0.

\section{A.5.3.2 Steel Drain Pipes}

The geometry, extent, and contents of the steel drain pipes will be inspected using visual inspection, a video survey, and/or an EM-31 (or equivalent) survey:

- The cement plugs will be cut off the ends of the pipes protruding from the wall of the drain pit. The ends will be visually inspected for the presence of sediment. In addition, the drain in the truck wash bay in the Birdwell Facility will be inspected for the presence of sediment.

- A video survey will be conducted to locate the upstream ends of the pipes and determine the presence or absence of sediment in the steel drain pipe(s).

- An EM-31 survey will be conducted to identify the upstream end(s) of the pipe(s).

- If visual inspection and/or the video survey locate sufficient quantities of sediment, samples will be collected. If the results are inconclusive, the pipe will be breached at a nominal midpoint, and an attempt will be made to collect a sediment sample at that location. Any samples collected will be analyzed for the chemical and radiological parameters provided in Section A.3.0. 


\section{A.6.0 Decision Rules}

The following decision rules are applicable to this investigation and will be used to guide the investigation and subsequent data evaluation:

- If, in the course of the investigation, either of the following occur, the investigation will be halted and rescoped as necessary:

- The conceptual model fails to such a degree that rescoping is required.

- Sufficient data are collected to support evaluation of corrective actions.

- If field screening indicates no COPCs above FSLs at a prescribed sampling location, a soil sample at the next prescribed sampling location will be field screened. If no COPCs are indicated, a confirmatory laboratory sample will be submitted from the upper interval.

- If field screening indicates the presence of COPCs above FSLs, the investigation will continue to determine the vertical and lateral extent of COPCs until FSRs are below FSLs; whereupon, a sample will be submitted for laboratory analysis to verify FSRs. Samples will be submitted for laboratory analysis from the subsurface interval that represents the highest FSR and at the discretion of the Site Supervisor. Additional samples may be required for waste management purposes.

- If laboratory results indicate the presence of contaminants of concern above PALs, a CADD will be prepared.

- If no COPCs are identified above PALs, a CADD/Closure Report will be prepared according to the outline agreed upon by NDEP and DOE/NV. This type of CADD incorporates the elements of the CADD and closure report and serves as the closure report for the site.

- If analytical results are not adequate for preparation of a CADD, additional step-out sampling may be conducted as a Stage II investigation.

\section{Additional Decision Rules for the Drain Pit Drain Pipe Investigation}

- If sediment/sludge is identified in the drain pipes in sufficient quantity for sample collection, a sample will be collected and submitted for laboratory analysis. The pipe(s) may be breached, as necessary, at the discretion of the Site Supervisor in an attempt to collect a sufficient quantity of sample material. If necessary, at the discretion of the Site Supervisor, samples from an individual pipe may be composited to obtain a sufficient amount of material for laboratory analysis. 
- If no sediment/sludge is identified in the drain pipes in sufficient quantity for sample collection or the investigative techniques prove inconclusive, the pipe(s) will be breached at a nominal midpoint and an attempt will be made to collect a sediment/sludge sample at that point. 


\section{A.7.0 Decision Error}

Biased sampling will be conducted at CAU 335 as identified in Sections A.4.0, A.5.0, and A.6.0. Biased sampling is appropriate because the CASs are well defined and process knowledge indicates that contamination, if any, is confined to the historical boundaries of the sites.

The biased sampling strategy targets worst-case contamination by sampling the Cased Hole and Drain Pit at locations with the highest potential for contamination. This sampling strategy will ensure that the extent of the contamination has been adequately located, identified, and quantified. Planned sample intervals may be substituted with intervals that exhibit the highest contamination levels for that sample location based on visual observation or other field-screening techniques. At least one sample with FSRs below FSLs will be obtained from each boring to define the lower limit of soil contamination (if any). FSRs will be confirmed by off-site laboratory analysis for these samples.

All soil samples will be field screened for VOCs and radionuclides. In addition, soil samples collected from the Cased Hole will be field screened for TPH. Field screening for TPH will be conducted at the Drain Pit, if a test kit using nonhazardous extraction solvents can be identified. This approach will minimize the potential for generating mixed waste at the Drain Pit, which is a possible radioactive site. Selected samples from each boring, as described in Sections A.5.1, A.5.2, and A.5.3, will be sent for off-site laboratory analysis for the appropriate COPCs listed in Tables A.3-1 and A.3-2. 


\section{A.8.0 References}

Bingham, F.E., Reynolds Electrical \& Engineering Co., Inc. 1992. Letter to J.D. Stewart (DOE/NV), entitled "Additional Information on Steam-Cleaning Operations on the Nevada Test Site (NTS),” 28 August. Las Vegas, NV.

Clark, G.A., Reynolds Electrical \& Engineering Co., Inc. 1991. Memorandum to D. Madsen (REECo), regarding Sample Analyses Results, 29 August. Las Vegas, NV.

DOE, see U.S. Department of Energy.

DOE/NV, see U.S. Department of Energy, Nevada Operations Office.

EPA, see U.S. Environmental Protection Agency.

Haworth, O.L., Reynolds Electrical \& Engineering Co., Inc. 1990. Letter to R.C. Keller (DOE/NV), regarding Oil Sump, Building 6-388 (Old Drilling Support Building), Area 6, 13 December. Las Vegas, NV.

H\&N, see Holmes \& Narver, Inc.

Holmes \& Narver, Inc. 1981. Engineering drawing JS-006-094-C1, titled "Birdwell \& National Cement Facilities Water \& Sewer System Plot Plan, Section \& Detail,” 29 April. Las Vegas, NV.

Hotsy Corporation. 1993. Material Safety Data Sheet for "Dayton 5W730 Heavy Duty Vehicle Cleaner," 15 June. Estherville, IA.

IT, see IT Corporation.

IT Corporation. 1993. Recompletion Report for Groundwater Characterization Project (GCP) Water Well 3, DOE/NV/10972-32. Prepared for the U.S. Department of Energy, Nevada Operations Office. Las Vegas, NV.

Meyers, J.S., and T.J. Nordenson. 1962. Evaporation from the 17 Western States With a Section on Evaporation Rates, USGS-PP-272-D. Denver, CO: U.S. Geological Survey.

NAC, see Nevada Administrative Code.

Nevada Administrative Code. 2000. NAC 445A.2272, "Contamination of Soil: Establishment of Action Levels." Carson City, NV: Nevada Division of Environmental Protection.

REECo, see Reynolds Electrical \& Engineering Co., Inc. 
Reynolds Electrical \& Engineering Co., Inc. 1990. Laboratory Analytical Results, Chain-of-Custody Documents, Sample Requests, and Logbook Entries for ER SITES within Areas 1-30, Vol. 4. Las Vegas, NV.

Reynolds Electrical \& Engineering Co., Inc. 1992. Detailed Site Activity Summary NTS Cleanup and Restoration, 14 May (updated). Prepared for the U.S. Department of Energy, Nevada Operations Office. Las Vegas, NV.

Sanders, P. 1995. Preliminary Ranking and Prioritization-DOE Defense Programs Sites at NTS, Rev. 1, 24 January.

Stoddard Building Company, Inc. Date Unknown. Engineering drawing titled "Birdwell Facility, Floor Plan." Las Vegas, NV.

U.S. Department of Energy. 1988. Environmental Survey Preliminary Report, Nevada Test Site, Mercury, Nevada, DOE/EH/OEV-15-P. Washington, DC: Environment, Safety and Health, Office of Environmental Audit.

U.S. Department of Energy, Nevada Operations Office. 1990. Environmental Survey Action Plan, Nevada Test Site, Mercury, Nevada. Las Vegas, NV.

U.S. Department of Energy, Nevada Operations Office. 1996. Industrial Sites Quality Assurance Project Plan, Nevada Test Site, Nevada, DOE/NV--372, Rev. 1. Las Vegas, NV.

U.S. Department of Energy, Nevada Operations Office. 2000. Nevada Test Site Resource Management Plan Annual Summary, January 2000, DOE/NV--604. Las Vegas, NV.

U.S. Environmental Protection Agency. 1999. Memorandum from S.J. Smucker to PRG table mailing list regarding Region 9 Preliminary Remediation Goals, 1 October. San Francisco, CA. 
Appendix B

\section{Project Organization}




\section{B.1.0 Project Organization}

The DOE/NV Industrial Sites Project Manager is Janet Appenzeller-Wing and her telephone number is (702) 295-0461.

The names of the project Health and Safety Officer and the Quality Assurance Officer can be found in the appropriate DOE/NV plan. However, personnel are subject to change, and it is suggested that the DOE/NV Industrial Sites Project Manager be contacted for further information. The DOE/NV Task Manager will be identified in the FFACO Biweekly Activity Report prior to the start of field activities. 


\section{Appendix C}

Laboratory Chemical, Toxicity Characteristic Leaching Procedure, and Radiochemistry Analytical Requirements for Industrial Sites 
Table C.1-1

\section{Laboratory Chemical, Toxicity Characteristic Leaching Procedure, and Radiochemistry Analytical Requirements for Industrial Sites}

(Page 1 of 6 )

\begin{tabular}{|c|c|c|c|c|c|c|}
\hline $\begin{array}{c}\text { Parameter or } \\
\text { Analyte }\end{array}$ & $\begin{array}{l}\text { Medium or } \\
\text { Matrix }\end{array}$ & $\begin{array}{l}\text { Analytical } \\
\text { Method }\end{array}$ & $\begin{array}{l}\text { Minimum } \\
\text { Reporting Limit }\end{array}$ & $\begin{array}{l}\text { Regulatory } \\
\text { Limit }\end{array}$ & $\begin{array}{c}\text { Relative } \\
\text { Percent } \\
\text { Difference } \\
\text { (RPD) }^{\mathrm{a}} \\
\end{array}$ & $\begin{array}{c}\text { Percent } \\
\text { Recovery } \\
(\% R)^{b}\end{array}$ \\
\hline \multicolumn{7}{|c|}{ ORGANICS } \\
\hline \multirow{2}{*}{$\begin{array}{c}\text { Total Volatile } \\
\text { Organic Compounds } \\
\text { (VOCs) }\end{array}$} & Water & \multirow{2}{*}{$8260 \mathrm{~B}^{\mathrm{c}}$} & \multirow{2}{*}{$\begin{array}{c}\text { Analyte-specific } \\
\text { estimated } \\
\text { quantitation limits }^{d}\end{array}$} & \multirow{2}{*}{$\begin{array}{c}\text { Not Applicable } \\
\text { (NA) }\end{array}$} & $14^{\mathrm{e}}$ & $61-145^{\mathrm{e}}$ \\
\hline & Soil & & & & $24^{e}$ & $59-172^{e}$ \\
\hline \multicolumn{7}{|l|}{$\begin{array}{c}\text { Toxicity } \\
\text { Characteristic } \\
\text { Leaching Procedure } \\
\text { (TCLP) VOCs }\end{array}$} \\
\hline Benzene & \multirow{10}{*}{ Aqueous } & \multirow{10}{*}{$1311 / 8260 \mathrm{~B}^{\mathrm{c}}$} & $0.050 \mathrm{mg} / \mathrm{L}^{d}$ & $0.5 \mathrm{mg} / \mathrm{L}^{\mathrm{d}}$ & \multirow{10}{*}{$14^{\mathrm{e}}$} & \multirow{10}{*}{$61-145^{\mathrm{e}}$} \\
\hline $\begin{array}{c}\text { Carbon } \\
\text { Tetrachloride }\end{array}$ & & & $0.050 \mathrm{mg} / \mathrm{L}^{\mathrm{d}}$ & $0.5 \mathrm{mg} / \mathrm{L}^{d}$ & & \\
\hline Chlorobenzene & & & $0.050 \mathrm{mg} / \mathrm{L}^{\mathrm{d}}$ & $100 \mathrm{mg} / \mathrm{L}^{\mathrm{d}}$ & & \\
\hline Chloroform & & & $0.050 \mathrm{mg} / \mathrm{L}^{d}$ & $6 \mathrm{mg} / \mathrm{L}^{d}$ & & \\
\hline 1,2-Dichloroethane & & & $0.050 \mathrm{mg} / \mathrm{L}^{\mathrm{d}}$ & $0.5 \mathrm{mg} / \mathrm{L}^{\mathrm{d}}$ & & \\
\hline 1,1-Dichloroethene & & & $0.050 \mathrm{mg} / \mathrm{L}^{d}$ & $0.7 \mathrm{mg} / \mathrm{L}^{\mathrm{d}}$ & & \\
\hline Methyl Ethyl Ketone & & & $0.050 \mathrm{mg} / \mathrm{L}^{\mathrm{d}}$ & $200 \mathrm{mg} / \mathrm{L}^{\mathrm{d}}$ & & \\
\hline Tetrachloroethene & & & $0.050 \mathrm{mg} / \mathrm{L}^{\mathrm{d}}$ & $0.7 \mathrm{mg} / \mathrm{L}^{\mathrm{d}}$ & & \\
\hline Trichloroethene & & & $0.050 \mathrm{mg} / \mathrm{L}^{d}$ & $0.5 \mathrm{mg} / \mathrm{L}^{\mathrm{d}}$ & & \\
\hline Vinyl Chloride & & & $0.050 \mathrm{mg} / \mathrm{L}^{\mathrm{d}}$ & $0.2 \mathrm{mg} / \mathrm{L}^{\mathrm{d}}$ & & \\
\hline \multirow{2}{*}{$\begin{array}{c}\text { Total Semivolatile } \\
\text { Organic Compounds } \\
\text { (SVOCs) }\end{array}$} & Water & \multirow{2}{*}{$8270 C^{c}$} & \multirow{2}{*}{$\begin{array}{c}\text { Analyte-specific } \\
\text { estimated } \\
\text { quantitation limits }^{d}\end{array}$} & \multirow{2}{*}{ NA } & $50^{\mathrm{e}}$ & $9-127^{e}$ \\
\hline & Soil & & & & $50^{e}$ & $11-142^{\mathrm{e}}$ \\
\hline \multicolumn{7}{|l|}{ TCLP SVOCs } \\
\hline o-Cresol & \multirow{6}{*}{ Aqueous } & \multirow{6}{*}{$1311 / 8270 C^{c}$} & $0.10 \mathrm{mg} / \mathrm{L}^{\mathrm{d}}$ & $200 \mathrm{mg} / \mathrm{L}^{\mathrm{d}}$ & \multirow{6}{*}{$50^{\mathrm{e}}$} & \multirow{6}{*}{$9-127^{e}$} \\
\hline m-Cresol & & & $0.10 \mathrm{mg} / \mathrm{L}^{\mathrm{d}}$ & $200 \mathrm{mg} / \mathrm{L}^{\mathrm{d}}$ & & \\
\hline p-Cresol & & & $0.10 \mathrm{mg} / \mathrm{L}^{\mathrm{d}}$ & $200 \mathrm{mg} / \mathrm{L}^{\mathrm{d}}$ & & \\
\hline Cresol (total) & & & $0.30 \mathrm{mg} / \mathrm{L}^{\mathrm{d}}$ & $200 \mathrm{mg} / \mathrm{L}^{d}$ & & \\
\hline $\begin{array}{l}\text { 1,4-Dichloro- } \\
\text { benzene }\end{array}$ & & & $0.10 \mathrm{mg} / \mathrm{L}^{\mathrm{d}}$ & $7.5 \mathrm{mg} / \mathrm{L}^{\mathrm{d}}$ & & \\
\hline 2,4-Dinitrotoluene & & & $0.10 \mathrm{mg} / \mathrm{L}^{\mathrm{d}}$ & $0.13 \mathrm{mg} / \mathrm{L}^{\mathrm{d}}$ & & \\
\hline
\end{tabular}


Table C.1-1

Laboratory Chemical, Toxicity Characteristic Leaching Procedure, and Radiochemistry Analytical Requirements for Industrial Sites

(Page 2 of 6 )

\begin{tabular}{|c|c|c|c|c|c|c|}
\hline $\begin{array}{l}\text { Parameter or } \\
\text { Analyte }\end{array}$ & $\begin{array}{l}\text { Medium or } \\
\text { Matrix }\end{array}$ & $\begin{array}{l}\text { Analytical } \\
\text { Method }\end{array}$ & $\begin{array}{c}\text { Minimum } \\
\text { Reporting Limit }\end{array}$ & $\begin{array}{l}\text { Regulatory } \\
\text { Limit }\end{array}$ & $\begin{array}{c}\text { Relative } \\
\text { Percent } \\
\text { Difference } \\
\text { (RPD) }^{\mathrm{a}} \\
\end{array}$ & $\begin{array}{c}\text { Percent } \\
\text { Recovery } \\
(\% R)^{b}\end{array}$ \\
\hline $\begin{array}{l}\text { Hexachloro- } \\
\text { benzene }\end{array}$ & \multirow{8}{*}{ Aqueous } & \multirow{8}{*}{$1311 / 8270 C^{c}$} & $0.10 \mathrm{mg} / \mathrm{L}^{\mathrm{d}}$ & $0.13 \mathrm{mg} / \mathrm{L}^{\mathrm{d}}$ & \multirow{8}{*}{$50^{\mathrm{e}}$} & \multirow{8}{*}{$9-127^{e}$} \\
\hline $\begin{array}{l}\text { Hexachloro- } \\
\text { butadiene }\end{array}$ & & & $0.10 \mathrm{mg} / \mathrm{L}^{\mathrm{d}}$ & $0.5 \mathrm{mg} / \mathrm{L}^{\mathrm{d}}$ & & \\
\hline $\begin{array}{l}\text { Hexachloro- } \\
\text { ethane }\end{array}$ & & & $0.10 \mathrm{mg} / \mathrm{L}^{\mathrm{d}}$ & $3 \mathrm{mg} / \mathrm{L}^{\mathrm{d}}$ & & \\
\hline Nitrobenzene & & & $0.10 \mathrm{mg} / \mathrm{L}^{\mathrm{d}}$ & $2 \mathrm{mg} / \mathrm{L}^{\mathrm{d}}$ & & \\
\hline $\begin{array}{l}\text { Pentachloro- } \\
\text { phenol }\end{array}$ & & & $0.50 \mathrm{mg} / \mathrm{L}^{\mathrm{d}}$ & $100 \mathrm{mg} / \mathrm{L}^{\mathrm{d}}$ & & \\
\hline Pyridine & & & $0.10 \mathrm{mg} / \mathrm{L}^{\mathrm{d}}$ & $5 \mathrm{mg} / \mathrm{L}^{\mathrm{d}}$ & & \\
\hline $\begin{array}{l}\text { 2,4,5-Trichloro- } \\
\text { phenol }\end{array}$ & & & $0.10 \mathrm{mg} / \mathrm{L}^{\mathrm{d}}$ & $400 \mathrm{mg} / \mathrm{L}^{\mathrm{d}}$ & & \\
\hline $\begin{array}{c}\text { 2,4,6-Trichloro- } \\
\text { phenol }\end{array}$ & & & $0.10 \mathrm{mg} / \mathrm{L}^{d}$ & $2 \mathrm{mg} / \mathrm{L}^{\mathrm{d}}$ & & \\
\hline \multirow{2}{*}{$\begin{array}{c}\text { Total } \\
\text { Pesticides }\end{array}$} & Water & \multirow{2}{*}{$8081 A^{c}$} & \multirow{2}{*}{$\begin{array}{l}\text { Analyte-specific } \\
\quad(C R Q L)^{e}\end{array}$} & \multirow{2}{*}{ NA } & $27^{e}$ & $38-131^{e}$ \\
\hline & Soil & & & & $50^{\circ}$ & $23-139^{e}$ \\
\hline \multicolumn{7}{|l|}{$\begin{array}{c}\text { TCLP } \\
\text { Pesticides }\end{array}$} \\
\hline Chlordane & \multirow{7}{*}{ Aqueous } & \multirow{7}{*}{$1311 / 8081 A^{c}$} & $0.0005 \mathrm{mg} / \mathrm{L}^{\mathrm{e}}$ & $0.03 \mathrm{mg} / \mathrm{L}^{\mathrm{d}}$ & \multirow{7}{*}{$27^{e}$} & \multirow{7}{*}{$38-131^{e}$} \\
\hline Endrin & & & $0.001 \mathrm{mg} / \mathrm{L}^{\mathrm{e}}$ & $0.02 \mathrm{mg} / \mathrm{L}^{\mathrm{d}}$ & & \\
\hline Heptachlor & & & $0.0005 \mathrm{mg} / \mathrm{L}^{\mathrm{e}}$ & $0.008 \mathrm{mg} / \mathrm{L}^{\mathrm{d}}$ & & \\
\hline $\begin{array}{l}\text { Heptachlor } \\
\text { Epoxide }\end{array}$ & & & $0.0005 \mathrm{mg} / \mathrm{L}^{\mathrm{e}}$ & $0.008 \mathrm{mg} / \mathrm{L}^{\mathrm{d}}$ & & \\
\hline $\begin{array}{c}\text { gamma-BHC } \\
\text { (Lindane) }\end{array}$ & & & $0.0005 \mathrm{mg} / \mathrm{L}^{\mathrm{e}}$ & $0.4 \mathrm{mg} / \mathrm{L}^{\mathrm{d}}$ & & \\
\hline Methoxychlor & & & $0.005 \mathrm{mg} / \mathrm{L}^{\mathrm{e}}$ & $10 \mathrm{mg} / \mathrm{L}^{\mathrm{d}}$ & & \\
\hline Toxaphene & & & $0.05 \mathrm{mg} / \mathrm{L}^{\mathrm{e}}$ & $0.5 \mathrm{mg} / \mathrm{L}^{\mathrm{d}}$ & & \\
\hline \multirow[b]{2}{*}{$\begin{array}{c}\text { Polychlorinated } \\
\text { Biphenyls (PCBs) }\end{array}$} & Water & \multirow[b]{2}{*}{$8082^{c}$} & \multirow{2}{*}{$\begin{array}{c}\text { Analyte-specific } \\
\text { contract-required } \\
\text { quantitation limits } \\
(\mathrm{CRQL})^{\mathrm{e}}\end{array}$} & \multirow[b]{2}{*}{ NA } & \multirow[b]{2}{*}{ Lab-specific ${ }^{\dagger}$} & \multirow[b]{2}{*}{ Lab-specific $^{\dagger}$} \\
\hline & Soil & & & & & \\
\hline \multirow{2}{*}{$\begin{array}{c}\text { Total } \\
\text { Herbicides }\end{array}$} & Water & \multirow{2}{*}{$8151 A^{c}$} & $1.3 \mu \mathrm{g} / \mathrm{L}^{\mathrm{c}}$ & \multirow{2}{*}{ NA } & \multirow{2}{*}{ Lab-specific ${ }^{\dagger}$} & \multirow{2}{*}{ Lab-specific $^{\dagger}$} \\
\hline & Soil & & $66 \mu \mathrm{g} / \mathrm{kg}^{\mathrm{c}}$ & & & \\
\hline \multicolumn{7}{|l|}{$\begin{array}{c}\text { TCLP } \\
\text { Herbicides }\end{array}$} \\
\hline $2,4-D$ & \multirow{2}{*}{ Aqueous } & \multirow{2}{*}{$1311 / 8151 A^{c}$} & $0.002 \mathrm{mg} / \mathrm{L}^{\mathrm{d}}$ & $10 \mathrm{mg} / \mathrm{L}^{\mathrm{d}}$ & \multirow{2}{*}{ Lab-specific $^{\dagger}$} & \multirow{2}{*}{ Lab-specific } \\
\hline $2,4,5-\mathrm{TP}$ & & & $0.00075 \mathrm{mg} / \mathrm{L}^{\mathrm{d}}$ & $1 \mathrm{mg} / \mathrm{L}^{\mathrm{d}}$ & & \\
\hline
\end{tabular}


Table C.1-1

Laboratory Chemical, Toxicity Characteristic Leaching Procedure, and Radiochemistry Analytical Requirements for Industrial Sites

(Page 3 of 6 )

\begin{tabular}{|c|c|c|c|c|c|c|}
\hline $\begin{array}{l}\text { Parameter or } \\
\text { Analyte }\end{array}$ & $\begin{array}{l}\text { Medium or } \\
\text { Matrix }\end{array}$ & $\begin{array}{l}\text { Analytical } \\
\text { Method }\end{array}$ & $\begin{array}{c}\text { Minimum } \\
\text { Reporting Limit }\end{array}$ & $\begin{array}{l}\text { Regulatory } \\
\text { Limit }\end{array}$ & $\begin{array}{l}\text { Relative } \\
\text { Percent } \\
\text { Difference } \\
\text { (RPD) }^{\mathrm{a}} \\
\end{array}$ & $\begin{array}{c}\text { Percent } \\
\text { Recovery } \\
(\% R)^{b}\end{array}$ \\
\hline \multirow{4}{*}{$\begin{array}{c}\text { Total Petroleum } \\
\text { Hydrocarbons (TPH) }\end{array}$} & $\begin{array}{c}\text { Water } \\
\text { Gasoline }\end{array}$ & \multirow{4}{*}{ 8015B modified ${ }^{c}$} & $0.1 \mathrm{mg} / \mathrm{L}^{\mathrm{g}}$ & \multirow{4}{*}{ NA } & \multirow{4}{*}{ Lab-specific $^{\dagger}$} & \multirow{4}{*}{ Lab-specific $^{\dagger}$} \\
\hline & Soil Gasoline & & $0.5 \mathrm{mg} / \mathrm{kg}^{\mathrm{g}}$ & & & \\
\hline & Water Diesel & & $0.5 \mathrm{mg} / \mathrm{L}^{\mathrm{g}}$ & & & \\
\hline & Soil Diesel & & $25 \mathrm{mg} / \mathrm{kg}^{\mathrm{g}}$ & & & \\
\hline \multirow{2}{*}{ Explosives } & Water & \multirow{2}{*}{$8330^{c}$} & $14 \mu \mathrm{g} / \mathrm{L}^{\mathrm{c}}$ & \multirow{2}{*}{ NA } & \multirow{2}{*}{ Lab-specific $^{\dagger}$} & \multirow{2}{*}{ Lab-specific $^{\dagger}$} \\
\hline & Soil & & $2.2 \mathrm{mg} / \mathrm{kg}^{\mathrm{c}}$ & & & \\
\hline \multirow{2}{*}{$\begin{array}{l}\text { Polychlorinated } \\
\text { Dioxins and Furans }\end{array}$} & Water & \multirow{2}{*}{$8280 \mathrm{~A} / 8290^{c}$} & $0.05 \mu \mathrm{g} / \mathrm{L}^{\mathrm{c}}$ & \multirow{2}{*}{ NA } & \multirow{2}{*}{ Lab-specific $^{\dagger}$} & \multirow{2}{*}{ Lab-specific $^{\dagger}$} \\
\hline & Soil & & $5 \mu \mathrm{g} / \mathrm{kg}^{\mathrm{c}}$ & & & \\
\hline \multicolumn{7}{|c|}{ INORGANICS } \\
\hline \multicolumn{7}{|l|}{$\begin{array}{c}\text { Total Resource } \\
\text { Conservation and } \\
\text { Recovery Act } \\
\text { (RCRA) Metals }\end{array}$} \\
\hline \multirow{2}{*}{ Arsenic } & Water & $6010 B^{c}$ & $10 \mu \mathrm{g} / \mathrm{L}^{\mathrm{g}, \mathrm{h}}$ & \multirow{16}{*}{ NA } & \multirow{16}{*}{$20^{h}$} & \multirow{16}{*}{$75-125^{\mathrm{h}}$} \\
\hline & Soil & $6010 B^{c}$ & $1 \mathrm{mg} / \mathrm{kg}^{\mathrm{g}, \mathrm{h}}$ & & & \\
\hline \multirow{2}{*}{ Barium } & Water & $6010 B^{c}$ & $200 \mu \mathrm{g} / \mathrm{L}^{\mathrm{g}, \mathrm{h}}$ & & & \\
\hline & Soil & $6010 \mathrm{~B}^{\mathrm{c}}$ & $20 \mathrm{mg} / \mathrm{kg}^{\mathrm{g}, \mathrm{h}}$ & & & \\
\hline \multirow{2}{*}{ Cadmium } & Water & $6010 B^{c}$ & $5 \mu \mathrm{g} / \mathrm{L}^{\mathrm{g}, \mathrm{h}}$ & & & \\
\hline & Soil & $6010 B^{c}$ & $0.5 \mathrm{mg} / \mathrm{kg}^{\mathrm{g}, \mathrm{h}}$ & & & \\
\hline \multirow{2}{*}{ Chromium } & Water & $6010 B^{c}$ & $10 \mu \mathrm{g} / \mathrm{L}^{\mathrm{g}, \mathrm{h}}$ & & & \\
\hline & Soil & $6010 B^{c}$ & $1 \mathrm{mg} / \mathrm{kg}^{\mathrm{g}, \mathrm{h}}$ & & & \\
\hline \multirow{2}{*}{ Lead } & Water & $6010 B^{c}$ & $3 \mu \mathrm{g} / \mathrm{L}^{\mathrm{g}, \mathrm{h}}$ & & & \\
\hline & Soil & $6010 B^{c}$ & $0.3 \mathrm{mg} / \mathrm{kg}^{\mathrm{g}, \mathrm{h}}$ & & & \\
\hline \multirow{2}{*}{ Mercury } & Water & $7470 A^{c}$ & $0.2 \mu \mathrm{g} / \mathrm{L}^{\mathrm{g}, \mathrm{h}}$ & & & \\
\hline & Soil & $7471 \mathrm{~A}^{\mathrm{c}}$ & $0.1 \mathrm{mg} / \mathrm{kg}^{\mathrm{g}, \mathrm{h}}$ & & & \\
\hline \multirow{2}{*}{ Selenium } & Water & $6010 B^{c}$ & $5 \mu \mathrm{g} / \mathrm{L}^{\mathrm{g}, \mathrm{h}}$ & & & \\
\hline & Soil & $6010 B^{c}$ & $0.5 \mathrm{mg} / \mathrm{kg}^{\mathrm{g}, \mathrm{h}}$ & & & \\
\hline \multirow{2}{*}{ Silver } & Water & $6010 \mathrm{~B}^{\mathrm{c}}$ & $10 \mu \mathrm{g} / \mathrm{L}^{\mathrm{g}, \mathrm{h}}$ & & & \\
\hline & Soil & $6010 \mathrm{~B}^{\mathrm{c}}$ & $1 \mathrm{mg} / \mathrm{kg}^{\mathrm{g}, \mathrm{h}}$ & & & \\
\hline
\end{tabular}


Table C.1-1

Laboratory Chemical, Toxicity Characteristic Leaching Procedure, and Radiochemistry Analytical Requirements for Industrial Sites

(Page 4 of 6 )

\begin{tabular}{|c|c|c|c|c|c|c|}
\hline $\begin{array}{c}\text { Parameter or } \\
\text { Analyte }\end{array}$ & $\begin{array}{l}\text { Medium or } \\
\text { Matrix }\end{array}$ & $\begin{array}{l}\text { Analytical } \\
\text { Method }\end{array}$ & $\begin{array}{c}\text { Minimum } \\
\text { Reporting Limit }\end{array}$ & $\begin{array}{l}\text { Regulatory } \\
\text { Limit }\end{array}$ & $\begin{array}{c}\text { Relative } \\
\text { Percent } \\
\text { Difference } \\
\text { (RPD) }{ }^{\mathrm{a}}\end{array}$ & $\begin{array}{c}\text { Percent } \\
\text { Recovery } \\
(\% R)^{b}\end{array}$ \\
\hline $\begin{array}{c}\text { TCLP RCRA } \\
\text { Metals }\end{array}$ & & & & & & \\
\hline Arsenic & \multirow{8}{*}{ Aqueous } & \multirow{8}{*}{$\begin{array}{l}1311 / 6010 B^{c} \\
1311 / 7470 A^{c}\end{array}$} & $0.10 \mathrm{mg} / \mathrm{L}^{\mathrm{g}, \mathrm{h}}$ & $5 \mathrm{mg} / \mathrm{L}^{\mathrm{d}}$ & \multirow{8}{*}{$20^{h}$} & \multirow{8}{*}{$75-125^{h}$} \\
\hline Barium & & & $2 \mathrm{mg} / \mathrm{L}^{\mathrm{g}, \mathrm{h}}$ & $100 \mathrm{mg} / \mathrm{L}^{\mathrm{d}}$ & & \\
\hline Cadmium & & & $0.05 \mathrm{mg} / \mathrm{L}^{\mathrm{g}, \mathrm{h}}$ & $1 \mathrm{mg} / \mathrm{L}^{\mathrm{d}}$ & & \\
\hline Chromium & & & $0.10 \mathrm{mg} / \mathrm{L}^{\mathrm{g}, \mathrm{h}}$ & $5 \mathrm{mg} / \mathrm{L}^{\mathrm{d}}$ & & \\
\hline Lead & & & $0.03 \mathrm{mg} / \mathrm{L}^{\mathrm{g}, \mathrm{h}}$ & $5 \mathrm{mg} / \mathrm{L}^{d}$ & & \\
\hline Mercury & & & $0.002 \mathrm{mg} / \mathrm{L}^{\mathrm{g}, \mathrm{h}}$ & $0.2 \mathrm{mg} / \mathrm{L}^{d}$ & & \\
\hline Selenium & & & $0.05 \mathrm{mg} / \mathrm{L}^{\mathrm{g}, \mathrm{h}}$ & $1 \mathrm{mg} / \mathrm{L}^{\mathrm{d}}$ & & \\
\hline Silver & & & $0.10 \mathrm{mg} / \mathrm{L}^{\mathrm{g}, \mathrm{h}}$ & $5 \mathrm{mg} / \mathrm{L}^{d}$ & & \\
\hline \multirow{2}{*}{ Cyanide } & Water & \multirow{2}{*}{$9010 \mathrm{~B}^{\mathrm{c}}$} & $0.01 \mathrm{mg} / \mathrm{L}^{\mathrm{h}}$ & \multirow{2}{*}{ NA } & \multirow{2}{*}{$20^{\mathrm{h}}$} & \multirow{2}{*}{$75-125^{h}$} \\
\hline & Soil & & $1.0 \mathrm{mg} / \mathrm{kg}^{\mathrm{h}}$ & & & \\
\hline \multirow[b]{2}{*}{ Sulfide } & Water & \multirow[b]{2}{*}{$9030 \mathrm{~B} / 9034^{\mathrm{C}}$} & $0.4 \mathrm{mg} / \mathrm{L}^{\mathrm{c}}$ & \multirow[b]{2}{*}{ NA } & \multirow[b]{2}{*}{ Lab-specific ${ }^{\dagger}$} & \multirow[b]{2}{*}{ Lab-specific } \\
\hline & $\begin{array}{c}\text { Soil or } \\
\text { Sediment }\end{array}$ & & $10 \mathrm{mg} / \mathrm{kg}^{\mathrm{g}}$ & & & \\
\hline \multirow{2}{*}{$\mathrm{pH} /$ Corrosivity } & Water & $9040 \mathrm{~B}^{\mathrm{c}}$ & \multirow{2}{*}{ NA } & $\mathrm{pH}>2^{\mathrm{i}}$ & \multirow{2}{*}{ Lab-specific ${ }^{\dagger}$} & \multirow{2}{*}{ Lab-specific } \\
\hline & Soil & $9045 C^{c}$ & & $\mathrm{pH}<12.5^{\mathrm{i}}$ & & \\
\hline \multirow[b]{2}{*}{ Ignitability } & Water & $1010^{c}$ & \multirow[b]{2}{*}{ NA } & $\begin{array}{c}\text { Flash Point } \\
<140^{\circ} \mathrm{F}^{\mathrm{d}}\end{array}$ & \multirow[b]{2}{*}{ NA } & \multirow[b]{2}{*}{ NA } \\
\hline & Soil & $1030^{c}$ & & $\begin{array}{c}\text { Burn Rate } \\
>2.2 \mathrm{~mm} / \mathrm{sec} \\
\text { nonmetals; } \\
>0.17 \mathrm{~mm} / \mathrm{sec} \\
\text { metals }\end{array}$ & & \\
\hline \multicolumn{7}{|c|}{ RADIOCHEMISTRY } \\
\hline \multirow{2}{*}{ Europium-152 } & Water & EPA $901.1^{\mathrm{j}}$ & $10.0 \mathrm{pCi} / \mathrm{L}^{\mathrm{k}}$ & \multirow{2}{*}{ NA } & 20 & \multirow{2}{*}{$80 \%-120 \%$} \\
\hline & Soil/Sediment & HASL 300' & $0.5 \mathrm{pCi} / \mathrm{g}$ & & 35 & \\
\hline \multirow{2}{*}{ Europium-154 } & Water & EPA $901.1^{\mathrm{j}}$ & $10.0 \mathrm{pCi} / \mathrm{L}^{\mathrm{k}}$ & \multirow{2}{*}{ NA } & 20 & \multirow{2}{*}{$80 \%-120 \%$} \\
\hline & Soil/Sediment & HASL 300' & $2.17 \mathrm{pCi} / \mathrm{g}$ & & 35 & \\
\hline \multirow{2}{*}{ Europium-155 } & Water & EPA $901.1^{j}$ & $10.0 \mathrm{pCi} / \mathrm{L}^{\mathrm{k}}$ & \multirow{2}{*}{ NA } & 20 & $80 \%$ \\
\hline & Soil/Sediment & HASL 300' & $0.5 \mathrm{pCi} / \mathrm{g}$ & & 35 & $00 \%-1<0 \%$ \\
\hline Colbolton & Water & EPA $901.1^{\mathrm{j}}$ & $10.0 \mathrm{pCi} / \mathrm{L}^{\mathrm{k}}$ & $\mathrm{NA}$ & 20 & ००० 1000 \\
\hline cobalt-bu & Soil/Sediment & HASL 300' & $0.66 \mathrm{pCi} / \mathrm{g}$ & NA & 35 & $80 \%-120 \%$ \\
\hline Cosium 127 & Water & EPA $901.1^{j}$ & $10.0 \mathrm{pCi} / \mathrm{L}^{\mathrm{k}}$ & NA & 20 & $80 \%-120 \%$ \\
\hline 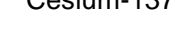 & Soil/Sediment & HASL 300' & $2.14 \mathrm{pCi} / \mathrm{g}$ & INA & 35 & \\
\hline
\end{tabular}


Table C.1-1

Laboratory Chemical, Toxicity Characteristic Leaching Procedure, and Radiochemistry Analytical Requirements for Industrial Sites

(Page 5 of 6 )

\begin{tabular}{|c|c|c|c|c|c|c|}
\hline $\begin{array}{c}\text { Parameter or } \\
\text { Analyte }\end{array}$ & $\begin{array}{l}\text { Medium or } \\
\text { Matrix }\end{array}$ & $\begin{array}{l}\text { Analytical } \\
\text { Method }\end{array}$ & $\begin{array}{c}\text { Minimum } \\
\text { Reporting Limit }\end{array}$ & $\begin{array}{l}\text { Regulatory } \\
\text { Limit }\end{array}$ & $\begin{array}{c}\text { Relative } \\
\text { Percent } \\
\text { Difference } \\
\text { (RPD) }{ }^{\mathrm{a}}\end{array}$ & $\begin{array}{c}\text { Percent } \\
\text { Recovery } \\
(\% R)^{b}\end{array}$ \\
\hline \multicolumn{7}{|c|}{ RADIOCHEMISTRY } \\
\hline \multirow{2}{*}{ Uranium-234 } & Water & $\begin{array}{c}\text { HASL } 300^{\prime} \text { or } \\
\text { ASTM D3972-97m }\end{array}$ & $0.37 \mathrm{pCi} / \mathrm{L}$ & \multirow{2}{*}{ NA } & 20 & \multirow{2}{*}{$80 \%-120 \%$} \\
\hline & Soil/Sediment & $\begin{array}{c}\text { HASL } 300^{\prime} \text { or } \\
\text { ASTM C1000-90m }\end{array}$ & $0.38 \mathrm{pCi} / \mathrm{g}$ & & 35 & \\
\hline \multirow{2}{*}{ Uranium-235 } & Water & $\begin{array}{c}\text { HASL } 300^{\prime} \text { or } \\
\text { ASTM D3972-97m }\end{array}$ & $0.32 \mathrm{pCi} / \mathrm{L}$ & \multirow{2}{*}{ NA } & 20 & \multirow{2}{*}{$80 \%-120 \%$} \\
\hline & Soil/Sediment & $\begin{array}{c}\text { HASL } 300^{\prime} \text { or } \\
\text { ASTM C1000-90m }\end{array}$ & $0.27 \mathrm{pCi} / \mathrm{g}$ & & 35 & \\
\hline \multirow{2}{*}{ Uranium-238 } & Water & $\begin{array}{c}\text { HASL } 300^{\prime} \text { or } \\
\text { ASTM D3972-97m }\end{array}$ & $0.33 \mathrm{pCi} / \mathrm{L}$ & \multirow{2}{*}{ NA } & 20 & \multirow{2}{*}{$80 \%-120 \%$} \\
\hline & Soil/Sediment & $\begin{array}{c}\text { HASL } 300^{\prime} \text { or } \\
\text { ASTM C } 1000-90^{m}\end{array}$ & $0.29 \mathrm{pCi} / \mathrm{g}$ & & 35 & \\
\hline \multirow{2}{*}{ Plutonium-238 } & Water & $\begin{array}{c}\text { HASL } 300^{\prime} \text { or } \\
\text { ASTM D3865-97m }\end{array}$ & $0.1 \mathrm{pCi} / \mathrm{L}$ & \multirow{2}{*}{ NA } & 20 & \multirow{2}{*}{$80 \%-120 \%$} \\
\hline & Soil/Sediment & $\begin{array}{c}\text { HASL } 300^{\prime} \text { or } \\
\text { ASTM C1001-90m }\end{array}$ & $0.05 \mathrm{pCi} / \mathrm{g}$ & & 35 & \\
\hline \multirow{2}{*}{ Plutonium-239/240 } & Water & $\begin{array}{c}\text { HASL } 300^{\prime} \text { or } \\
\text { ASTM D3865-97 }\end{array}$ & $0.1 \mathrm{pCi} / \mathrm{L}$ & \multirow{2}{*}{ NA } & 20 & \multirow{2}{*}{$80 \%-120 \%$} \\
\hline & Soil/Sediment & $\begin{array}{c}\text { HASL } 300^{\prime} \text { or } \\
\text { ASTM C1001-90 }\end{array}$ & $0.05 \mathrm{pCi} / \mathrm{g}$ & & 35 & \\
\hline \multirow{2}{*}{ Strontium - 90} & Water & ASTM D5811-95 & $1.0 \mathrm{pCi} / \mathrm{L}$ & \multirow{2}{*}{ NA } & 20 & \multirow{2}{*}{$80 \%-120 \%$} \\
\hline & Soil/Sediment & ASTM D5811-95 & $0.5 \mathrm{pCi} / \mathrm{g}$ & & 35 & \\
\hline \multirow{2}{*}{$\begin{array}{c}\text { Gross Alpha and } \\
\text { Gross Beta }\end{array}$} & Water & EPA $900.0^{j}$ & $4.0 \mathrm{pCi} / \mathrm{L}$ & \multirow{2}{*}{ NA } & 20 & \multirow{2}{*}{$80 \%-120 \%$} \\
\hline & Soil/Sediment & Lab-Specific $^{\circ}$ & $4.0 \mathrm{pCi} / \mathrm{g}$ & & 35 & \\
\hline Tritium & Water & EPA 906.0 & $400.0 \mathrm{pCi} / \mathrm{L}$ & NA & 20 & $80 \%-120 \%$ \\
\hline Isotope-Specific ${ }^{n}$ & Soil/Water & Lab-Specific $^{\circ}$ & $\begin{array}{l}\text { Isotope- and } \\
\text { method-specific }\end{array}$ & NA & $\begin{array}{c}35 \text { soil } \\
20 \text { water }\end{array}$ & $80 \%-120 \%$ \\
\hline
\end{tabular}




\section{Table C.1-1 \\ Laboratory Chemical, Toxicity Characteristic Leaching Procedure, and Radiochemistry Analytical Requirements for Industrial Sites (Page 6 of 6 )}

${ }^{\text {aRPD }}$ is used to calculate precision.

Precision is estimated from the relative percent difference of the concentrations measured for the matrix spike and matrix spike duplicate analyses of unspiked field samples, or field duplicates of unspiked samples. It is calculated by:

$R P D=100 \times\left\{\left(\left|C_{1}-C_{2}\right|\right) /\left[\left(C_{1}+C_{2}\right) / 2\right]\right\}$, where $C_{1}=$ Concentration of the analyte in the first sample aliquot, $C_{2}=$ Concentration of the analyte in the second sample aliquot.

b\%R is used to calculate accuracy.

Accuracy is assessed from the recovery of analytes spiked into a blank or sample matrix of interest, or from the recovery of surrogate compounds spiked into each sample. The recovery of each spiked analyte is calculated by: $\% R=100 \times\left(C_{s}-C_{u} / C_{n}\right)$, where $C_{s}=$ Concentration of the analyte in the spiked sample, $C_{u}=$ Concentration of the analyte in the unspiked sample, $\mathrm{C}_{\mathrm{n}}=$ Concentration increase that should result from spiking the sample

'U.S. Environmental Protection Agency (EPA), Test Methods for Evaluating Solid Waste, 3rd Edition, Parts 1-4, SW-846

(EPA, 1996)

'Estimated Quantitation Limit as given in SW-846 (EPA, 1996)

EEPA Contract Laboratory Program Statement of Work for Organic Analysis (EPA, 1988b; 1991; and 1994b)

${ }^{\dagger}$ In-House Generated RPD and \%R Performance Criteria

It is necessary for laboratories to develop in-house performance criteria and compare them to those in the methods. The laboratory begins by analyzing 15-20 samples of each matrix and calculating the mean \%R for each analyte. The standard deviation (SD) of each \%R is then calculated, and the warning and control limits for each analyte are established at \pm 2 SD and \pm 3 SD from the mean, respectively. If the warning limit is exceeded during the analysis of any sample delivery group (SDG), the laboratory institutes corrective action to bring the analytical system back into control. If the control limit is exceeded, the sample results for that SDG are considered unacceptable. These limits are reviewed after every 20-30 field samples of the same matrix and are updated at least semiannually. The laboratory tracks trends in both performance and control limits by the use of control charts. The laboratory's compliance with these requirements is confirmed as part of an annual laboratory audit. Similar procedures are followed in order to generate acceptance criteria for precision measurements.

IIndustrial Sites Quality Assurance Project Plan (DOE/NV, 1996)

hEPA Contract Laboratory Program Statement of Work for Inorganic Analysis (EPA, 1988a; 1994a; and 1995)

'RCRA Regulations and Keyword Index, 1998 Edition

'Prescribed Procedures for Measurements of Radioactivity in Drinking Water (EPA, 1980) or equivalent method

${ }^{\mathrm{k}}$ Detection limit is based upon method and isotope; the detection limit for special requests will be pre-approved

'Environmental Measurements Laboratory Procedures Manual, 28th Edition (DOE, 1997) or equivalent method

${ }^{m}$ American Society for Testing and Materials

n'Special request isotopes

'Laboratory-specific method is to be pre-approved prior to analysis.

Definitions:

$\mu \mathrm{g} / \mathrm{kg}=$ Microgram(s) per kilogram

$\mathrm{mg} / \mathrm{kg}=$ Milligram(s) per kilogram

$\mathrm{pCi} / \mathrm{L}=$ Picocurie(s) per liter $\mathrm{mg} / \mathrm{L}=$ Milligram $(\mathrm{s})$ per liter $\mathrm{pCi} / \mathrm{g}=$ Picocurie $(\mathrm{s})$ per gram $\mu \mathrm{g} / \mathrm{L}=$ Microgram(s) per liter 


\section{C.1.0 References}

RCRA Regulations and Keyword Index. 1998. ISSN 1074-1364. New York, NY: Elsevier Science, Inc.

U.S. Department of Energy. 1997. Environmental Measurements Laboratory Procedures Manual, HASL-300, 28th Edition, Vol. 1. New York, NY.

U.S. Department of Energy, Nevada Operations Office. 1996. Industrial Sites Quality Assurance Project Plan, Nevada Test Site, Nevada, DOE/NV--372. Las Vegas, NV.

U.S. Environmental Protection Agency. 1980. Prescribed Procedures for Measurements of Radioactivity in Drinking Water, EPA-600/4-79-020. Washington, DC.

U.S. Environmental Protection Agency. 1988a. Contract Laboratory Program Statement of Work for Inorganic Analysis, SOW No. 788, EPA/540/R-94/093. Washington, DC.

U.S. Environmental Protection Agency. 1988b. Contract Laboratory Program Statement of Work for Organic Analysis, SOW No. 2/88, EPA/540/R-94//096. Washington, DC.

U.S. Environmental Protection Agency. 1991. Contract Laboratory Program Statement of Work for Organic Analysis, OLMO 1.8, EPA/540/R-94/078. Washington, DC.

U.S. Environmental Protection Agency. 1994a. Contract Laboratory Program Statement of Work for Inorganic Analysis, ILMO 3.0, EPA/540/R-94/076. Washington, DC.

U.S. Environmental Protection Agency. 1994b. Contract Laboratory Program Statement of Work for Organic Analysis, OLMO 3.1, EPA/540/R-94/073. Washington, DC.

U.S. Environmental Protection Agency. 1995. Contract Laboratory Program Statement of Work for Inorganic Analysis, ILMO 4.0, EPA/540/R-95/121. Washington, DC.

U.S. Environmental Protection Agency. 1996. Test Methods for Evaluating Solid Waste, Physical/Chemical Methods, SW-846, $3^{\text {rd }}$ Edition (CD ROM, PB97-501928 GEI includes revisions to 1986, 1992, and 1994). Washington, DC. 


\section{Appendix D}

\section{NDEP Comments}




\section{NEVADA ENVIRONMENTAL RESTORATION PROJECT}

\section{DOCUMENT REVIEW SHEET}

\begin{tabular}{|c|c|c|c|c|c|}
\hline \multicolumn{4}{|c|}{$\begin{array}{l}\text { 1. Document Title/Number: Draft Corrective Action Investigation Plan for Corrective Action Unit 335: Area } 6 \\
\text { Injection Well and Drain Pit, Nevada Test Site, Nevada }\end{array}$} & \multicolumn{2}{|l|}{ 2. Document Date: September 2000} \\
\hline \multicolumn{4}{|c|}{ 3. Revision Number: 0} & \multicolumn{2}{|c|}{ 4. Originator/Organization: IT Corporation } \\
\hline \multicolumn{4}{|c|}{ 5. Responsible DOE/NV ERP Project Mgr.: Janet Appenzeller-Wing } & \multicolumn{2}{|c|}{ 6. Date Comments Due: October 19, 2000} \\
\hline \multicolumn{6}{|c|}{ 7. Review Criteria: Full } \\
\hline \multicolumn{4}{|c|}{ 8. Reviewer/Organization/Phone No.: Greg Raab, NDEP, 486-2867 } & \multicolumn{2}{|l|}{ 9. Reviewer's Signature: } \\
\hline $\begin{array}{l}\text { 10. Comment } \\
\text { Number/ } \\
\text { Location }\end{array}$ & 11. Type ${ }^{a}$ & 12. Comment & \multicolumn{2}{|c|}{ 13. Comment Response } & 14. Accept \\
\hline $\begin{array}{l}\text { 1. Page } 14 \text { of } 44 \\
\text { 1st Paragraph, } \\
\text { Last Sentence }\end{array}$ & & $\begin{array}{l}\text { Italicized portion of the following is the comment: } \\
\text { "...Since the hydrocarbon staining is no longer present, this area of } \\
\text { the Drain Pit will not be sampled...". DOE must provide a more } \\
\text { substantial proof that there are no TPHs present other than the } \\
\text { absence of staining. A biased sampling approach for the Drain Pit } \\
\text { would provide data to demonstrate the presence/absence of TPHs. }\end{array}$ & \multicolumn{2}{|c|}{$\begin{array}{l}\text { Sentence deleted. Sections } 4.4 .2 \text { and A.5.2 modified to } \\
\text { show that five borings will be located equidistant along the } \\
\text { southern edge of the Drain Pit to characterize the possible } \\
\text { hydrocarbon staining noted during a site visit. }\end{array}$} & Yes \\
\hline
\end{tabular}

${ }^{\text {a }}$ Comment Types: $M=$ Mandatory, $S=$ Suggested .

Return Document Review Sheets to DOE/NV Environmental Restoration Division, Attn: QAC, M/S 505. 


\section{Distribution}

*Provide copy in distribution of Rev. 0 and subsequent revisions if applicable. Copies of only the NDEP-approved document will be distributed to others.

Paul J. Liebendorfer

State of Nevada

Bureau of Federal Facilities

Division of Environmental Protection

333 W. Nye Lane, Room 138

Carson City, NV 89706-0851

Michael McKinnon

State of Nevada

Bureau of Federal Facilities

Division of Environmental Protection

555 E. Washington, Suite 4300

Las Vegas, NV 89101

Sabrina Lawrence

Environmental Restoration Division

DOE/Nevada Operations Office

P.O. Box 98518, M/S 505

Las Vegas, NV 89193-8518

Janet Appenzeller-Wing

Environmental Restoration Division

DOE/Nevada Operations Office

P.O. Box 98518, M/S 505

Las Vegas, NV 89193-8518

Sabine Curtis

Environmental Restoration Division

DOE/Nevada Operations Office

P.O. Box 98518, M/S 505

Las Vegas, NV 89193-8518

Wayne Johnson

Bechtel Nevada

P.O. Box 98521, M/S NTS306

Las Vegas, NV 89193-8521
2 (Controlled)*

1 (Controlled)*

1 (Controlled)*

1 (Uncontrolled)*

1 (Uncontrolled)*

1 (Uncontrolled)* 
Tom Fitemaurice

Bechtel Nevada

P.O. Box 98521, M/S NTS306

Las Vegas, NV 89193-8521

Jerel Nelson

Bechtel Nevada

P.O. Box 98521, M/S NTS306

Las Vegas, NV 89193-8521

Trenton Richards

ITLV

P.O. Box 93838

Las Vegas, NV 89193

IT Corporation Central Files

P.O. Box 93838

Las Vegas, NV 89193

John Davis

ITLV

P.O. Box 93838

Las Vegas, NV 89193

Technical Information Resource Center

DOE/Nevada Operations Office

P.O. Box 98518, M/S 505

Las Vegas, NV 89193-8518

U.S. Department of Energy

Office of Scientific and Technical Information

P.O. Box 62

Oak Ridge, TN 37831

Manager, Southern Nevada FFACO

Public Reading Facility

P.O. Box 98521, M/S NLV040

Las Vegas, NV 89193-8521

Manager, Northern Nevada FFACO

Public Reading Facility

c/o Nevada State Library and Archives

Federal Publications

100 North Stewart Street

Carson City, NV 89071-4285
1 (Uncontrolled)*

1 (Uncontrolled)*

1 (Uncontrolled)*

1 (Uncontrolled)*

1 (Controlled)*

1 (Uncontrolled)

1 (Uncontrolled electronic copy only)

1 (Controlled)

1 (Uncontrolled)

1 (Uncontrolled) 
IT FFACO Support Office

1 (Controlled)

IT Corporation

P.O. Box 93838

Las Vegas, NV 89193 